\title{
The Alchemical Patronage of Sir William Cecil, Lord Burghley
}

James Stuart Campbell

A thesis submitted to the Victoria University of Wellington in fulfilment of the requirements for the degree of Master of Arts in History

Victoria University of Wellington

2009 
Image 1:

Attr. Hans Eworth, 'William Cecil, Lord Burghley', c.1565

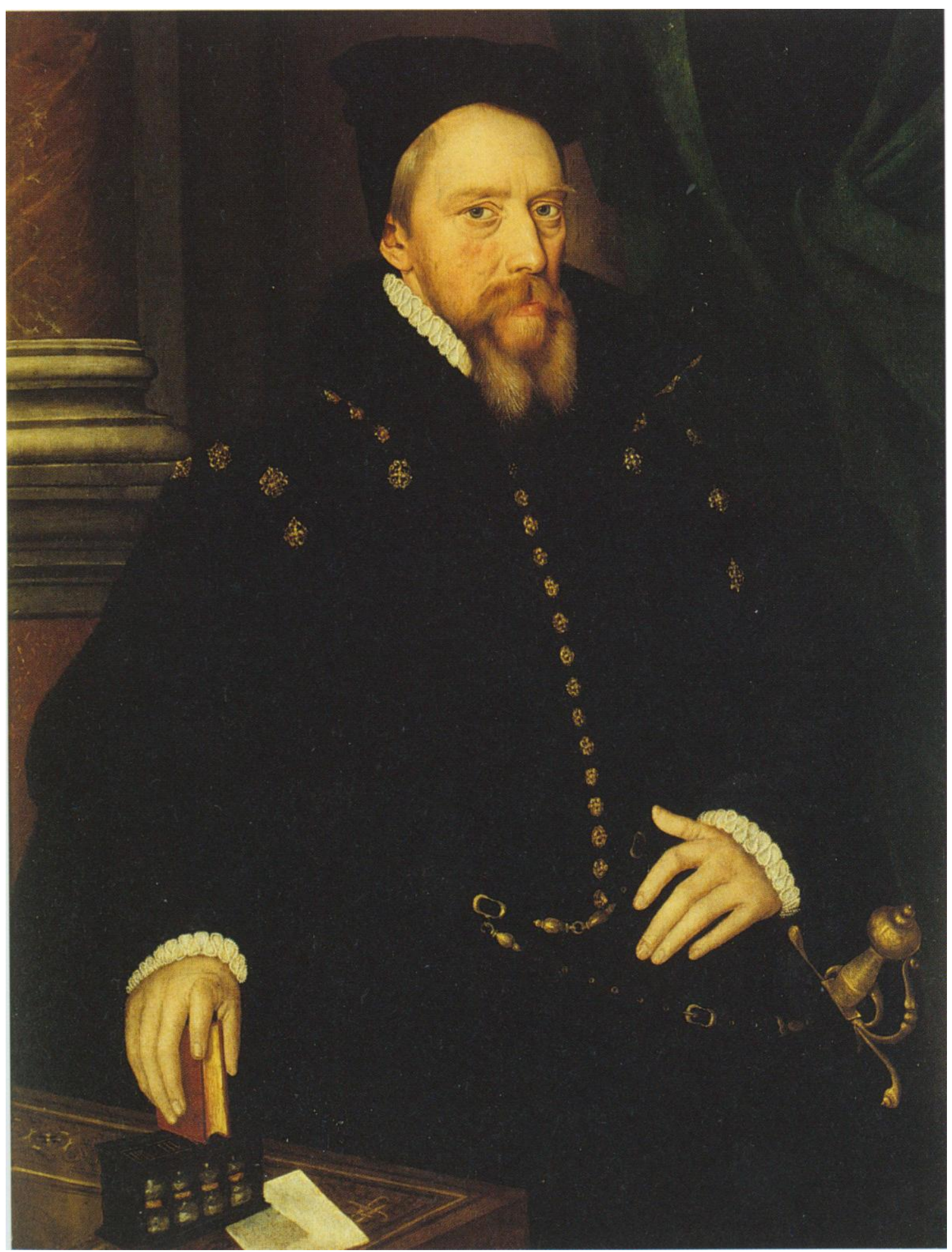

Source: Pauline Croft (ed.), Patronage, Culture and Power, New Haven, 2002, p. xxvii. 


\begin{abstract}
This thesis examines the alchemical patronage of Sir William Cecil, Lord Burghley (15201598), Principal Secretary and later Lord Treasurer to Queen Elizabeth I. Through an examination of Cecil's surviving papers, along with other primary manuscript and printed works, it places Cecil's patronage of alchemy within the context of both his previous examined patronage and the intellectual context of sixteenth century England. This thesis analyses why Cecil, a key member of government for over fifty years and Elizabeth's most trusted councillor, believed in the legitimacy of alchemical solutions to both national and personal problems. To explain Cecil's trust in alchemy, the thesis focuses first on his understanding of nature. It argues that a belief in alchemical transmutation was an essential consequence of an education that emphasised an Aristotelian understanding of the universe. Cecil was therefore receptive of demonstrations of theoretical as well as practical alchemical knowledge. Through an assessment of Cecil's neglected medical patronage, the thesis also argues that he was amongst the first in England to utilise new alchemically based medical treatments. In his role as Elizabeth's chief minister, Cecil administered a number of alchemical projects intended to support both Crown finances and England's industrial competitiveness. In light of Cecil's integral role in these projects, the thesis contends that he saw alchemy as a legitimate method of addressing both his short and long term policy aims. This thesis therefore both provides a more complete understanding of Cecil's patronage and adds to the limited historiography of alchemy in Elizabethan England.
\end{abstract}




\section{Contents}

Abstract iii

Acknowledgments v v v

List of Images $v i$

List of Abbreviations vii

Note on Dates and Transcription viii

Introduction 1

1. Cecil and Alchemical Philosophy in the Elizabethan Age 17

2. Alchemical Medicine 52

3. Alchemy and Crown Finances 76

—Cornelius de Lannoy $\quad 78$

$\begin{array}{ll}\text { —Edward Kelley } & 87\end{array}$

$\begin{array}{ll}\text {-Roloff Peterson } & 107\end{array}$

4. Alchemy and Economic Projects 117

—The Frobisher Ores 118

—William Medley and the Society of the New Art 128

$\begin{array}{ll}\text { Conclusion } & 154\end{array}$

$\begin{array}{ll}\text { Bibliography } & 160\end{array}$ 


\section{Acknowledgements}

Thanks must first go to my supervisor Glyn Parry for his invaluable advice and guidance, without which this thesis would not have been completed. Thanks also to my fellow postgraduate students Nick Radburn, Malcolm Craig, Michael Devine, Michael Gill, Sam Ritchie and Susie Johnston, for providing their invaluable friendship and advice. I am extremely grateful to Brenda and Aporo Joyce for awarding me the Jack Pearce Scholarship and to the History Department for providing a comfortable and accommodating working environment. I am also appreciative of the feedback and correspondence of a number of academics, especially Steve Behrendt and Peter Grund. Special thanks go to my family and friends for their encouragement and support throughout my MA. 


\section{List of Images}

1. Attr. Hans Eworth, 'William Cecil, Lord Burghley', c.1565,

as reproduced in Pauline Croft (ed.), Patronage, Culture and

Power, New Haven, 2002, p. xxvii.

2. Anon., 'Burchart's furnice', Undated, TNA, SP 12/122/63

3. Anon., 'A ploote of the woorkes and havens now fit for that

purpose', undated, TNA, SP 45/36 MPF11 


\section{List of Abbreviations}

$A P C$

BL

CMS

CPR

CSPD

CSPF

TNA

PROB

SP
Acts of the Privy Council of England

The British Library

Calendar of the Manuscripts of the Most Honourable the Marquis of Salisbury, Preserved at Hatfield House, Hertfordshire

Calendar of the Patent Rolls

Preserved in the Public Record Office

Calendar of State Papers Domestic

Calendar of State Papers Foreign

The National Archives of the United Kingdom

Records of the Prerogative Court of Canterbury

State Papers 


\section{Note on Dates and Transcription}

As most documents cited in this thesis are either of English origin, or predate the introduction of the Gregorian calendar in Catholic Europe in 1582, dating is given in the Julian style. Where documents have been dated in the Gregorian style this has been adjusted. For the sake of clarity 1 January is taken as the New Year throughout, and the date-year has been adjusted accordingly.

All primary material has been presented using original spelling and grammar, with some minor exceptions. For the sake of clarity, common sixteenth century transpositions, such as ' $v$ ' for ' $u$ ' and ' $i$ ' for ' $j$ ' have been adjusted to modern spelling. Common contractions, such as ' $\mathrm{M} \mathrm{j}^{\text {tie, }}$ for 'Majesty', ' $\mathrm{w}^{\text {th' }}$ for 'with', and ' $\mathrm{w}^{\text {ch' }}$ for 'which', have been expanded. Primary documents reproduced in secondary collections have been quoted verbatim, retaining the modernising conventions of their editors. 


\section{Introduction}

William Cecil, through the careful acquisition of royal favour, became Queen Elizabeth I's most trusted counsellor. As the Queen's Principal Secretary, Cecil was the gatekeeper to royal patronage, and exercised enormous influence over England's domestic and foreign policy. Even before he became Lord Burghley in 1571 and Lord Treasurer the following year, Cecil's affluence and influence allowed him to become an important patron in his own right. ${ }^{1}$ Historians, therefore, have considered Cecil to be one of the most important figures of the Elizabethan regime. As such he has been the subject of an immense amount of historical research analysing his impact on England's economic, religious, and foreign policy. This thesis examines a hitherto overlooked aspect of Cecil's career: his patronage of alchemy. The research for this thesis has uncovered neglected evidence of Cecil's relationship with a number of alchemists and alchemical projects, revealing their involvement in his intricate network of patronage.

As a result of his Aristotelian education, Cecil shared with the alchemists a unified view of nature. This natural philosophy encouraged the Elizabethan elite to believe in humanity's ability to perfect the world both spiritually and physically. The alchemist's quest to achieve perfection-gold in the case of base metals and spiritual redemption in the case of humanity—correspondingly appealed to many renaissance intellectuals. While, like many Elizabethans, Cecil could be sceptical about some alchemical promises, the concept of transmutation was consistent with his understanding of the world. Where Cecil differed from his contemporaries was in his determination to utilize alchemical knowledge for the benefit of both himself and the Elizabethan state. Throughout his career he patronised, invested in, and supported a remarkable range of alchemical activities. A detailed

\footnotetext{
${ }^{1}$ From his ennoblement as Lord Burghley on 25 February 1571, Cecil became known by his title. As this thesis is not entirely chronological, for the purposes of clarity he will be referred to as Cecil throughout.
} 
examination of primary evidence reveals a man deeply enthusiastic about alchemy in many forms, from philosophy and medicine, through to industrial metallurgy.

This thesis examines the support, both financial and political, which Cecil lent to a number of alchemical projects throughout the Elizabethan period. The underlying objective of the thesis is to consider the implications of Cecil's continued support for alchemical projects on our understanding of the mentality of the Elizabethan Court. Together with contextualising the position of alchemical thought and practice within Elizabethan society, the thesis examines alchemy as one of Cecil's legitimate domestic and foreign policy tools, and analyses the degree to which the philosophical ideals and concepts of alchemy appealed to Cecil's religious, political and philosophical beliefs. The thesis also argues that potential clients knew about and took advantage of Cecil's interest in alchemy. Numerous patronage suits directed at Cecil included demonstrations of both practical and theoretical forms of alchemical knowledge. This thesis therefore argues that contemporaries widely recognised Cecil's predilection towards alchemical patronage.

Since the Enlightenment, historians studying Cecil have chosen to ignore the great statesman's belief in the reality of alchemical transmutation. To them such a belief did not correspond with their conception of a pragmatic and capable manager of government business. The few historical discussions of Cecil's interest in alchemical schemes therefore tend to be dismissive or superficial.

The work of John Strype (1643-1737) has channelled the interests of subsequent historians of Cecil. Whilst Strype never completed his biography of Cecil, he based much of his writing, especially his four volume Annals of the Reformation (1709-31), on that part of Cecil's papers now in the Lansdowne Collection. ${ }^{2}$ Despite his claims of objectivity, Stype's work reflected both the interests and prejudices of the Enlightenment period. The derisive

${ }^{2}$ G. H. Martin and Anita McConnell, 'Strype, John (1643-1737)', Oxford Dictionary of National Biography, Oxford, Sept 2004; online edn, Jan 2008 [http://www.oxforddnb.com/view/article/26690]. 
late seventeenth and early eighteenth century attitude towards 'irrational' concepts such as alchemy and astrology is particularly evident in his writing. Strype, writing at the height of the scientific revolution's emphasis on rationality and reason, usually found it easiest to overlook Cecil's interest in alchemy.

When alchemical patronage came to the forefront of Cecil's correspondence, Strype conveniently ascribed some other motive to his actions. This is evident in his discussion of Cecil's correspondence with the alchemist Edward Kelley. Strype decided that "the curiosity of the subject, and eminency of the person [Cecil]" warranted the printing of large sections of the letters both in his text and appendix. ${ }^{3}$ On rather slim evidence he presumed that Cecil sought Kelley primarily as a political informant rather than for his purported alchemical skills. ${ }^{4}$ This supposition has strongly influenced almost all subsequent historians' interpretations of this episode. ${ }^{5}$

Strype often included original documents in appendices. Whilst this has preserved some letters that have since been destroyed, his documentary selections reflected his personal prejudices, and their accessibility has since shaped the interests and perspectives of historians. ${ }^{6}$ As a clergyman he emphasised Cecil's religious policy, and almost totally ignored many other topics. Too many historians have relied on his usually accurate, although often silently abridged, transcriptions of difficult to access manuscripts, making Strype's particular biases incredibly pervasive, even three centuries later. Historians as eminent as David Quinn, in his biography of Sir Humphrey Gilbert, have repeated ad nauseam Strype's treatment of one of Cecil's alchemical projects, the Society of the New Art. $^{7}$

\footnotetext{
${ }^{3}$ John Strype, Annals of the Reformation and Establishment of Religion and other Various Occurrences in the Church of England During Queen Elizabeth's Happy Reign, , Vol. 3, Part 2, Oxford, 1728, reprinted 1824, p. 132.

${ }^{4}$ Ibid., pp. 132-33.

${ }^{5}$ Edward Nares, Memoirs of the Life and Administration of the Right Honourable William Cecil, Lord Burghley, London, 1828, p. 340; Michael Wilding, 'A Biography of Edward Kelly, the English Alchemist and Associate of Dr. John Dee', in Stanton J. Linden, Mystical Metal of Gold: Essays on Alchemy and Renaissance Culture, New York, 2007, pp. 61-62.

${ }^{6}$ Martin and McConnell, 'Strype, John (1643-1737)'.

${ }^{7}$ David B. Quinn, The Voyages and Colonising Enterprises of Sir Humphrey Gilbert, London, 1940.
} 
Nineteenth century biographers of Cecil, such as Edward Nares, were concerned almost entirely with the narrative history of his political career, and gave little thought to either Cecil's ideas or patronage. ${ }^{8}$ Nares, famously derided by Thomas Macaulay as being "so utterly incompetent to arrange the materials which he has collected, that he might as well have left them in their original repositories", ignores alchemy completely. ${ }^{9}$ Later biographies such as Martin Hume's The Great Lord Burghley; a Study in Elizabethan Statecraft (1898) did much the same, with neither alchemy, nor any of Cecil's alchemical projects, warranting a mention. ${ }^{10}$

Not until the political historian Conyers Read's twin volumes, Mr Secretary Cecil and Queen Elizabeth (1955) and Lord Burghley and Queen Elizabeth (1960), was a thoroughly scholarly account of Cecil's life produced. ${ }^{11}$ Read was the first to recognise the inherent problems of studying Cecil: the lack of Cecil's own voice in the sources; the complicated relationship between Cecil and the Queen; and the constant fluctuation of fortunes at Court that affected even the Queen's closest advisors. In doing so he produced a far more nuanced view of Cecil's political motivations and actions. Read recognised that while Cecil was not, as Thomas Macaulay described him, "by nature and habit one of those who follow, not one of those who lead", neither was he, as J. A. Froude had it, solely responsible for the glories of Elizabethan policy, which the ineffectual Queen "starved and mutilated when energy and completeness were most needed". ${ }^{12}$

For all its strengths, Read's work contains a number of flaws. Attempting to deal with the vast number of relevant records, Read inevitably concentrated on that part of Cecil's life in which he was most interested: his political career, especially in relation to foreign policy. Read gave Cecil's private life, personal interests, patronage, and even

\footnotetext{
${ }^{8}$ Edward Nares, Memoirs of the Life and Administration.

${ }_{9}$ Macaulay, Thomas, R. H. Horne (ed.), Scenes and Characters from the Writings of Thomas Babington Macaulay, Oxford, 1846, p. 206.

${ }^{10}$ Martin Hume, The Great Lord Burghley-Study In Elizabethan Statecraft, London, 1898.

${ }^{11}$ Conyers Read, Mr Secretary Cecil and Queen Elizabeth, London, 1955; Conyers Read, Lord Burghley and Queen Elizabeth, London, 1960.

12 Thomas Macaulay, R. H. Horne (ed.), Scenes and Characters, p. 206; J. A. Froude, History of England from the Fall of Wolsey to the Defeat of the Spanish Armada, Vol. 12, London, 1881, p. 508.
} 
economic policy, only cursory examination. For example, although Read details elements of his education, he does not ask how Cecil's time at Cambridge University influenced his worldview. ${ }^{13}$ Furthermore, whilst Read refers to manuscripts from many of the available archives, he often relies on those printed in works such as William Murdin's Collection of State Papers Relating to Affairs in the Reign of Queen Elizabeth (1759), further narrowing his field of enquiry. ${ }^{14}$ This may also have been responsible for Read perpetuating several longstanding and largely erroneous assumptions, such as of a Court factionalised by deep seated hostility between Cecil and Robert Dudley, Earl of Leicester. ${ }^{15}$ In reality while the two often differed on policy, they also often worked together cordially and effectively. ${ }^{16}$ Michael Graves' criticism that Read “offers no clearly defined image or assessment of Burghley" is largely accurate. ${ }^{17}$

When Read did encounter one of Cecil's alchemical projects, he, like many other political historians, disparaged their importance. Cecil's involvement in the Society of the New Art's attempts to transmute iron into copper is described as "a little adventure in alchemy" that inevitably came to nothing. ${ }^{18}$ To Read the whole project, which had been one of Cecil's chief domestic concerns for over three years, served only to "show that like all his fellows even Burghley succumbed on occasion to the alluring promises of the alchemists". 19

Read found Cecil's protracted attempts to convince the alchemist Edward Kelley to return to England more problematic and provided some details of the episode. Read had difficulty in reconciling the pragmatic administrator and politician of his biography with the credulous dupe who would plead for an alchemist to help restore Crown finances. Concluding that "the whole story is an incredible one", Read admitted that "Burghley was a

\footnotetext{
${ }^{13}$ Read, Mr Secretary Cecil, pp. 25-28. Elizabeth, London, 1759.

${ }^{15}$ Read, Lord Burghley, pp. 316-17.

${ }^{16}$ Michael Graves, Burghley: William Cecil, Lord Burghley, London, 1998, pp. 122-4.

${ }^{17}$ Ibid., p. 10.

${ }^{18}$ Read, Lord Burghley, p. 145.

${ }^{19}$ Ibid., p. 145.
}

${ }^{14}$ Read also references John Strype's often inaccurate transcriptions. See Read, Mr Secretary Cecil, pp. 469-495; Read, Lord Burghley, pp. 549-603; William Murdin, Collection of State Papers Relating to Affairs in the Reign of Queen 
creature of his time, sceptical of magic, but ready to exploit it for all that it might be worth." ${ }^{20}$ While Cecil was always careful and pragmatic, he certainly never showed signs of scepticism about the possibility of alchemical transmutation.

Whilst there have been a number of subsequent biographies of Cecil, none of them provide any substantive analysis of Cecil's alchemical patronage. B. W. Beckingsale's Burghley: Tudor Statesman, 1520-1598 (1967) attempted to create a more fully-rounded view of Cecil by dividing his study into two parts: the first outlined Cecil's political career; while the second dealt with his character, patronage and policy achievements. Beckingsale briefly acknowledged that Cecil's Cambridge mentors' scientific interests encouraged his alchemical patronage, and that his hopes of successful transmutation were "no more sanguine than those of the leading alchemists of the day." ${ }^{21}$ However, Beckingsale neither provided any detail about this patronage nor any analysis of how alchemy corresponded with Cecil's worldview. Although Michael Graves' slim 1998 biography of Cecil identifies many of the issues facing any comprehensive study of Cecil's life, it is too insubstantial to provide much more than a cursory overview of his career, overlooking any examples of alchemical patronage. ${ }^{22}$ Popular histories such as David Loades' The Cecils: Privilege and Power behind the Throne (2007) tend to omit entirely any mention of Cecil's interest in alchemy. ${ }^{23}$

Cecil's most prominent recent biography, Stephen Alford's Burghley: William Cecil at the Court of Elizabeth I (2008) continued this trend. ${ }^{24}$ Whilst providing an eminently readable account of Cecil's life, Alford brings little in the way of new information or interpretation to bear on his subject. He may have succeeded in removing Cecil's reputation as a grey, conservative, bureaucrat, instead depicting him as "brilliant, controlled and to his enemies terrifying". 25 However, no one familiar with Elizabethan Court history would argue

${ }^{20}$ Read, Lord Burghley, p 476.

${ }^{21}$ B. W. Beckingsale, Burghley: Tudor Statesman, 1520-1598, London, 1967, pp. 258, 261.

22 Michael Graves, Burghley: William Cecil, Lord Burghley, London, 1998.

${ }^{23}$ David Loades, The Cecil's: Privilege and Power bebind the Throne, Richmond, 2007.

${ }^{24}$ Stephen Alford, Burghley: William Cecil at the Court of Elizabeth I, New Haven, 2008.

${ }^{25}$ Ibid., p. xi. 
otherwise. The dull, elderly, bureaucrat is merely a figment of recent popular fiction. ${ }^{26}$ The major fault with Alford's work, however, is the selectivity of his coverage. For example, Alford's treatment of the last ten years of Cecil's career is completely inadequate. This last decade, which engaged England in a desperate war with Spain, and in which Court politics descended into open factionalism, is considered in far less detail than the rest of Elizabeth's reign. ${ }^{27}$ Unsurprisingly, Alford also fails to consider Cecil's views on alchemy. Aside from passing reference to the alchemists John Dee and Richard Eden, Alford mentions none of alchemical projects examined in this thesis. ${ }^{28}$

A few instances of Cecil's alchemical patronage have been partially described in biographies of other Tudor statesmen, notably Mary Dewar's Sir Thomas Smith (1964) and Ralph Sargent's The Life and Lyrics of Sir Edward Dyer (1935). Dewar devoted a chapter to Sir Thomas Smith's involvement in the Society of the New Art, using far more sources than Strype, and hence wrote a much more accurate account. However, she paid little attention to the scheme's broader implications, and misunderstood the manner in which the project ended. ${ }^{29}$ Sargent's account of Edward Dyer's role as Cecil's emissary to Edward Kelley also improved on that given by Strype, but he still only examined a minority of the sources relating to the episode. ${ }^{30}$ Neither author focussed on Cecil's role as a patron of alchemy.

Monographs dealing with particular elements of either Cecil's career or the Elizabethan regime have begun to provide a more well-rounded view of the Elizabethan period. Yet, even when these studies have examined closely related topics, Cecil's alchemical patronage has been studiously ignored. In 'The Economic Patronage of William Cecil', Felicity Heal and Clive Holmes provide a detailed and insightful overview of Cecil's

\footnotetext{
26 Alford's examples of history having remembered Cecil as a dull bureaucrat are either from older works such as John Neale's biography of Queen Elizabeth, or recent cinema such as Shekhar Kapur's Elizabeth (1998); Alford, Burghley, p. xii.; John Neale, Queen Elizabeth I, London, 1973.

27 Alford, Burghley, pp. 296-331.

${ }^{28}$ Ibid., p. 17.

${ }^{29}$ Mary Dewar, Sir Thomas Smith, London, 1964, pp. 149-155.

${ }^{30}$ Ralph Sargent, The Life and Lyrics of Sir Edward Dyer, Oxford, 1935, $2^{\text {nd }}$ Edition, 1968, pp. 97-122.
} 
support for economic projects. Describing Cecil as "the pre-eminent patron of projects intended to improve and expand the economy of England", Heal and Holmes demonstrate that Cecil's economic policies were designed to marry older concerns for stability and the maintenance of authority with newer mercantilist reforms. ${ }^{31}$ However, even Heal and Holmes only briefly mention Cecil being "seduced into support of unlikely ventures, such as Cornelius de Lannoy's claims for the 'new art', or alchemic transmutation". ${ }^{2}$ They consider such missteps essentially out of character. ${ }^{33}$ They relegate Cecil's involvement in the Society of the New Art to a footnote, in which they emphasise that "Cecil was more cautious than his colleague in advancing cash" and refer the reader to Dewar's account. ${ }^{34}$ If Heal and Holmes had been less dismissive of alchemical patronage, they would have found that the Society of the New Art matched some of their case studies of economic patronage in both ambition and expense. If Cecil invested less in the project than the governor of the Society, Sir Thomas Smith, he was certainly the last to give up on the scheme, and would continue to patronise William Medley, the alchemist involved, for many years afterwards. ${ }^{35}$

Cecil's biographers' failure to differentiate alchemy from notions of popular magic reflects a common misunderstanding of Renaissance alchemical concepts. To a large extent this demonstrates the influence of nineteenth century occultists, such as Mary Anne Atwood, on popular conceptions of alchemy. Her influential A Suggestive Inquiry into the Hermetic Mystery (1850) interpreted alchemy as simply an allegorical expression of esoteric spiritual knowledge. ${ }^{36}$ Alchemy has therefore become overly associated with spiritualism, witchcraft, and other forms of magical belief. This misinterpretation of alchemy, advanced

\footnotetext{
${ }^{31}$ Felicity Heal and Clive Holmes, 'The Economic Patronage of William Cecil' in Pauline Croft, Patronage, Culture and Power: The Early Cecils 1558 - 1612, London, 2002, p. 223.

32 Ibid., p. 203.

33 Ibid.

34 Ibid., p. 229n.

${ }^{35}$ Edward Osborne and Wolstan Dixie to William Cecil, 12 September 1576, Cecil Papers, vol. 160, No.111.

${ }^{36}$ Mary Anne Atwood, A Suggestive Inquiry into the Hermetic Mystery, London, 1850.
} 
by such prolific authors as A. E. Waite, further separated alchemy from the other more accepted aspects of intellectual history. ${ }^{37}$ Recent scholars have outlined the continuing effect that nineteenth century spiritualists have had on the scholarly study of alchemy, with many of their assumptions still evident in historical discussion. ${ }^{38}$

Whilst alchemy certainly took on a spiritual dimension, especially in the minds of philosophers such as Cornelius Agrippa and later Robert Fludd, it would be a mistake to assume that this correlation was universal. Alchemists' aims ranged from purely spiritual transformation to the physical transmutation of metals. This thesis classifies alchemy as occult only for lack of a better term and then only with reservations. Its meaning should been taken as referring to the Renaissance search for the hidden knowledge of the unity of matter and creation, rather than the esoteric spiritualism born in the nineteenth century. To the Elizabethan elite alchemy was not part of "the spells and curses of popular imagination, but a philosophical outlook which animated human attempts to control nature", and hence requires separate evaluation. ${ }^{39}$

The scholarly study of alchemy and occultism improved from the 1920s. Lynn Thorndyke's ground breaking eight volume work $A$ History of Magic and Experimental Science (1923-58) and the 1937 inauguration of the Society for the History of Alchemy and Chemistry's journal Ambix, established alchemy as a legitimate subject for scholarly attention. ${ }^{40}$ Many historians of science, however, continued to consider alchemy as merely an illogical precursor to modern chemistry, to be studied only for that reason. They tended to regard Renaissance alchemy as something particularly primitive and a "continuing embarrassment in the story of genuine science". ${ }^{41}$ Herbert Butterworth in his Origins of

\footnotetext{
${ }^{37}$ Lawrence M. Principe and William R. Newman, 'Some Problems with the Historiography of Alchemy', in William R. Newman and Anthony Grafton (eds.), Secrets of Nature: Astrology and Alchemy in Early Modern Europe, Cambridge (Mass.), 2001, pp. 393-95.

${ }^{38}$ Ibid.

39 Vaughan Hart, Art and Magic in the Court of the Stuarts, London, 1994, p 1.

${ }^{40}$ Lynn Thorndike, A History of Magic and Experimental Science, 8 Vols., London, 1923-58.

${ }^{41}$ Brian Copenhaver, 'Hermes Trismegistus, Proclus, and the Question of a Philosophy of Magic in the Renaissance' in Ingrid Merkel and Allen Debus (eds.), Hermeticism and the Renaissance, London, 1988.
} 
Modern Science 1300-1800 (1951) famously described historians of alchemy as "tinctured with the kind of lunacy they set out to describe". ${ }^{42}$

This presentist view, which assigned little historical importance to alchemy because it conflicted with current scientific concepts, predominated until the 1960s. In that decade, Frances Yates argued that a cohesive Renaissance philosophy of magical and hermetic ideas played an essential role in the Scientific Revolution, thereby transforming the study of Renaissance ideas. Despite subsequent criticism, the so called "Yates thesis", which argued, for example, that John Dee's obsession with Renaissance magic "could pass into, and stimulate, the will to operate in genuine applied science", caused historians to reassess the influence of occult knowledge, a process that continues today. ${ }^{43}$ Scholars such as Walter Pagel, Allen G. Debus, Nicholas Clulee and Stanton Linden have since helped to reintegrate alchemy, along with elements of magic, Neoplatonist philosophy, and Paracelsian medicine, into the mainstream history of science. ${ }^{44}$

Perhaps the most influential general study of early modern magical practices has been Keith Thomas' seminal work Religion and the Decline of Magic (1971) ${ }^{45}$ In describing the links between changing religious practices and belief in witchcraft, astrology, and magic, Thomas created a convincing explanation for the decline of popular magical beliefs by the end of the seventeenth century. Whilst Thomas' three hundred year time span meant that his argument remained very broad, he did briefly discuss some aspects of Cecil's mentality that would seem to contradict his pragmatic reputation, specifically his belief in astrological prediction and in the unlucky nature of certain days. ${ }^{46}$ Thomas' treatment of alchemy was inadequate in comparison. Because he relied principally on printed material, Thomas

\footnotetext{
${ }^{42}$ Herbert Butterfield, The Origins of Modern Science, 1300-1800, New York, 1951, p. 98.

${ }^{43}$ Frances Yates, Giordano Bruno and the Hermetic Tradition, Chicago, 1964, p. 150.

${ }^{44}$ See Alan Debus, The Chemical Promise: Experiment and Mysticism in the Chemical Philosophy 1550-1800, Sagamore Beach 2006; Walter Pagel, Paracelsus: An Introduction to Philosophical Medicine in the Era of the Renaissance, Basel, 1958; Nicholas Clulee, John Dee's Natural Philosophy: Between Science and Religion, London, 1988; Stanton J. Linden, The Alchemy Reader: From Hermes Trismegistus to Isaac Newton, Cambridge, 2003.

${ }^{45}$ Keith Thomas, Religion and the Decline of Magic: Studies in Popular Beliefs in Sixteenth and Seventeenth Century England, Oxford, 1971.

${ }^{46}$ Ibid., p. 616.
} 
marginalised the importance of alchemical ideas, which were primarily transmitted in manuscript form until the beginning of the seventeenth century. ${ }^{47}$

It is therefore remarkable, given the advances made in the history of alchemy, that alchemical patronage in England has been the subject of very little scholarly enquiry. The few recent studies of alchemical patronage have all examined continental Europe. In Rudolf II and His World: A Study in Intellectual History 1576-1612 (1973), R. J. W. Evans sought to understand not only the Holy Roman Emperor's patronage of occult philosophy, but the intellectual milieu of his Prague court. ${ }^{48}$ Recent publications by Bruce Moran, Pamela Smith, and Tara Nummedal, have also established that "alchemy had a particular ideological resonance with early modern rulers" that motivated their intellectual and practical interest in alchemy. ${ }^{49}$ European rulers embraced alchemical concepts because they corresponded to their understanding of nature and offered solutions to both political and practical problems.

In contrast, historians have ignored the importance of alchemical patronage in England. Stephen Pumfrey and Frances Dawbarn's article 'Science and Patronage in England, 1570-1625: A Preliminary Study' dismissed alchemical patronage in England as unimportant. ${ }^{50}$ Whilst they described Cecil's involvement in the Society of the New Art as "the most extraordinary of Burghley's projects" they failed to relate it to Cecil's interest in alchemy. ${ }^{51}$ Rather, they asserted that while "some European courts had both practical and philosophical interests in alchemy, there is scant evidence that Elizabeth's politicians had

\footnotetext{
${ }^{47}$ Ibid., p. 270.

${ }^{48}$ R. J. W. Evans, Rudolf II and His World: A Study in Intellectual History 1576-1612, Oxford, 1973.

${ }^{49}$ Bruce Moran (ed.), Patronage and Institutions: Science, Technology, and Medicine at the European Court, 1500-1750, New York, 1991; Tara Nummedal, Alchemy and Authority in the Holy Roman Empire, Chicago, 2007, p. 9.

50 Stephen Pumfrey and Francis Dawbarn, 'Science and Patronage in England, 1570-1625: A Preliminary Study', History of Science, Vol. 42, 2004, pp. 137-88.

${ }^{51}$ Ibid., p. 159.
} 
interest in its occultist theory". ${ }^{52}$ They then argued that Cecil's firmly utilitarian attitude towards natural knowledge typified English patronage.

This interpretation is flawed in a number of respects. Firstly Dawbarn and Pumfrey failed to differentiate between alchemical philosophy and occultist theory. As previously mentioned, alchemical knowledge did not necessarily take on an overtly occult character in the sixteenth century. This thesis argues that Cecil's philosophical resonance with alchemical concepts encouraged his patronage of a number of alchemical projects, even if they were primarily utilitarian in nature. Secondly they seem to have ignored recent work by historians examining the patronage of alchemy in the German princedoms. Bruce Moran and Tara Nummedal have demonstrated the tendency of less secure, usually Protestant, regimes to focus on using alchemy for "technical solutions to political problems". ${ }^{53}$ Whilst this could also be interpreted as utilitarian patronage, German princes such as Moritz of Hesse were no less intellectually committed to an alchemical understanding of nature than ostentatious patrons such as Emperor Rudolf II..$^{54}$

Deborah Harkness' book The Jewel House: Elizabethan London and the Scientific Revolution (2007) is perhaps the only work that has attempted to place Cecil's support for alchemy within his wider patronage. ${ }^{55}$ Harkness portrayed Cecil has the architect of what she called "Elizabethan Big Science", large scale projects designed to transform England "financially, militarily, and geopolitically by investing in science and technology". 56 However, in her view the important element of these projects was London's vibrant scientific community, rather than Cecil. Harkness' discussion of alchemy was also very brief, and marred by numerous basic errors in research.

\footnotetext{
52 Ibid., p. 160.

53 Bruce Moran, The Alchemical World of the German Court, Stuttgart, 1991, p. 174.

54 Ibid., p. 174.

${ }^{55}$ Deborah Harkness, The Jewel House: Elizabethan London and the Scientific Revolution, New Haven, 2007.

56 Ibid., p.143.
} 
Many of the distortions in the historiography of Cecil can be traced to limitations in the surviving records. As Principal Secretary to the Queen, and later as Lord Treasurer, Cecil received, intercepted, read, responded to, and stored huge volumes of incoming correspondence. A high proportion of these letters survive today, scattered across a number of manuscript collections in the British National Archives and elsewhere. The Cecil papers in Hatfield House alone comprise more than 900,000 manuscript folios. ${ }^{57}$ However, only a small portion of Cecil's outgoing letters survive, forcing historians to evaluate much of what he wrote by his correspondents' replies. This lack of direct written evidence has exacerbated historians' tendency to impose their own, rationalist mindset on Cecil. Nowhere is this more evident than in the few discussions of Cecil's alchemical patronage.

The dispersal of Cecil's papers has also altered historians' interpretations. Upon his death in 1598 one portion of his papers remained in the state records; another he left to his second son Robert; and a third portion was appropriated by his personal secretary Michael Hickes. ${ }^{58}$ That part of Cecil's papers left in state hands forms the majority of the domestic and foreign English State Papers in the National Archives, with part finding their way into other collections such as the Cotton Manuscripts. ${ }^{59}$ Robert Cecil's share, along with his own papers, remain in his family home, Hatfield House, and form perhaps the most important private collection of early modern English manuscripts. ${ }^{60}$ That portion of Cecil's papers obtained by Michael Hickes was acquired by Lord Lansdowne, first Earl of Shelbourne, in the eighteenth century and now resides in the British Library as part of the Lansdowne Collection. ${ }^{61}$ Whilst these collections differ slightly in their focus, both thematically and chronologically, records of any one important episode in Cecil's life are

\footnotetext{
${ }^{57}$ Stephen Alford, 'The Collection of the Cecil Papers, Hatfield House, Hertfordshire', State Papers Online, 1509-1714, Cengage Learning EMEA Ltd, Reading, 2009.

58 Stephen Alford, 'State Papers of Edward VI, Mary I and Elizabeth I: the Archives and the Documents', State Papers Online, 1509-1714, Cengage Learning, Reading 2007.

${ }^{59}$ Simon Adams, 'The Tudor State Papers in the Yelverton, Cotton and Harleian Manuscript Collections', State Papers Online, 1509-1714, Cengage Learning, Reading, 2009.

${ }^{60}$ Stephen Alford, 'The Collection of the Cecil Papers, Hatfield House, Hertfordshire', State Papers Online, 1509-1714, Cengage Learning EMEA Ltd, Reading, 2009.

${ }^{61}$ Stephen Alford, 'State Papers of Edward VI, Mary I and Elizabeth I'.
} 
usually spread across all of them. The separation of these collections has often given historians an incomplete understanding of Cecil's career.

The Victorian archivists, who took the masses of manuscripts that survived in the State Paper Office and elsewhere, and arranged, catalogued, and calendared them, have also had an enormous influence on research into Elizabethan history. As Stephen Alford rightly claims, "when we look at these Tudor sources we have to recognise that we view them through a Victorian lens." ${ }^{, 2}$ The nineteenth century calendars reflect what the Victorians arranging and writing them thought was important in the sources. Also, the need in the earliest published calendars to summarise long letters into little more than a sentence often hides the true substance of the material. Hence Armigil Waad's long letter to Cecil discussing both the progress of Cornelius de Lannoy's attempts to create alchemical gold for the Queen, and John Prestall's offer of alchemical services is summarised as

Ar[migill] Waade to Cecill. Progress of the manufacture of glass and pottery, under Cornelius de Lannoy. Clumsiness of the English glassmakers. Recommends the suits of Henric Literhows, Mr. Prestoll, and William Herle. ${ }^{63}$

Without examining the manuscript the reader would have no clue of its relation to alchemy. It is therefore not surprising that this episode has received little attention from historians.

The digitisation of early modern manuscripts onto various online databases has finally mitigated the effects of both the dispersal of Cecil's papers and the distorting lenses of the state paper calendars. Through the thorough examination of the original documents digitised from many of the scattered archives, it is now possible to construct a more balanced assessment of Cecil and therefore challenge many historical assumptions regarding his alchemical patronage. Even so, the Hatfield House collection remains

62 Stephen Alford, 'Introduction to State Papers Online and the Sixteenth Century State Papers, 1509-1603', State Papers Online, 1509-1714, Cengage Learning, Reading, 2007.

${ }^{63}$ R. Lemon (ed.), CSPD 1547-1580, London, 1856, p. 256; Armigil Waad to Cecil, 7 August 1565, TNA, SP $12 / 37 / 3$. 
difficult to access with microfilm copies only available in the British and Folger libraries. Fortunately the Hatfield calendars are relatively comprehensive, often reproducing almost compete transcripts of the original manuscripts.

This thesis uses Cecil's enormous manuscript collection, in combination with other state papers and contemporary published works, to examine his belief in the philosophical ideals and practical possibility of alchemy. It contextualises Cecil's patronage of alchemy within both the worldview promulgated by Renaissance humanism, and Cecil's overriding interest in the security of England's Protestant state. In doing so it argues that rather than the irrational hope of a fool, Cecil's belief in alchemy was a fundamental consequence of his comprehension of the world, built upon an Aristotelian education that emphasised a unified understanding of nature.

Chapter one focuses on alchemical philosophy as part of Cecil's understanding of nature, beginning with a brief background sketch of the alchemical concepts prevalent in the mid sixteenth century. It considers both the prominence of alchemical concepts within Cecil's university education and the outlook of those scholars with whom he most closely associated. Using both Cecil's later correspondence with the Cambridge scholars John Dee and Richard Eden, and the antiquarian and alchemist Francis Thynne's appeals for his patronage, it examines the extent to which Cecil's education established a continuing fascination with alchemical philosophy and practice.

Chapter two investigates Cecil's patronage of chemical medicine. By establishing the position of chemical practitioners in the medical marketplace it reveals the prevalence of alchemical ideas in Elizabethan medicine. It then explores the use of chemical medicine amongst physicians whom Cecil is known to have consulted, and also those whose offers of medical assistance have no extant replies. Finally it considers Humfrey Lock and Samuel Norton's attempts to appeal to Cecil using explicitly alchemical medical theory. In light of 
these examples it argues that Cecil was known by contemporaries to favour chemical medicine.

Chapter three analyses Cecil's repeated attempts to use alchemy to relieve strained Crown finances. It first examines the degree to which he encouraged and managed the Dutch alchemist Cornelius de Lannoy's attempts to create alchemical riches in the 1560 s. Then it considers Cecil's involvement in two of the Elizabethan government's later attempts to profit from alchemical knowledge. Firstly, his efforts to facilitate the return of the alchemist Edward Kelley from Bohemia to England are reassessed in an attempt to avoid the presentist interpretations of previous historians. Secondly, it analyses Cecil's role in the Court's attempts to profit from the alchemical equipment of Roloff Peterson in the 1590s.

Chapter four discusses whether Cecil considered alchemy to be a potential method for improving England's industrial competitiveness. It examines whether alchemy encouraged the excessive investment in the second and third Frobisher voyages, and the extent of Cecil's support for the venture. Then it presents a detailed analysis of his patronage of the alchemist William Medley and their joint role in the Society of the New Art's attempts to transmute iron into copper. By contextualising the patronage of industrial alchemy within Cecil's already established policy of English economic expansion, it presents a more complete picture of Cecil's economic patronage.

Through an examination of Cecil's alchemical patronage, this thesis adds to the limited historiography of Elizabethan alchemy. It therefore hopes to shed light on a number of questions regarding alchemy in the wider Elizabethan and European contexts. Was Cecil a driver of Elizabethan alchemical patronage or did he merely reflect the attitude of the rest of the Court? To what degree did Elizabethan views on alchemy mirror their continental contemporaries? How had these attitudes shifted by the end of Elizabeth's reign? 


\section{Chapter 1: Cecil and Alchemical Philosophy in the}

\section{Elizabethan Age}

To understand Cecil's patronage of alchemy it is essential to appreciate his affinity with alchemical ideas. Historians such as R. J. W. Evans, Bruce Moran and Tara Nummedal have demonstrated that the continental European nobility shared a metaphorical understanding of nature, and thus they "viewed alchemy not only as possible, but often as central to their intellectual, religious, and political activities". However, the implications of this for English elites have not been widely examined. The lack of scholarship on the relationship between early modern English university education and alchemical theory has therefore impaired historians' understanding of the Elizabethan penchant for alchemical patronage.

This chapter examines the extent to which alchemical thought complemented Cecil's own understanding of nature. To a significant degree, Cecil's comprehension of the universe was a product of his education at Cambridge University. This chapter therefore analyses the relationship between alchemical philosophy as it existed in the sixteenth century and the humanist philosophy of the English universities. In the context of Cecil's two most influential tutors-John Cheke and Thomas Smith-and their interest in alchemy, this chapter argues that informal private study also disseminated occult concepts. It then investigates Cecil's relationship with three Elizabethan alchemists: his academic contemporaries John Dee and Richard Eden; and the antiquarian Francis Thynne. By examining Cecil's patronage of their theoretical alchemical knowledge, this chapter contends that the unified metaphorical worldview inculcated in Cecil by his thorough university education encouraged his fascination with alchemical concepts.

\footnotetext{
${ }^{1}$ Tara Nummedal, 'Practical Alchemy and Commercial Exchange in the Holy Roman Empire', in Pamela Smith and Paula Findlen (eds.), Merchants \& Marvels: Commerce, Science, and Art in Early Modern Europe, New York, 2002, p. 202.
} 
In its broadest sense alchemy sought "states of perfection, gold in the case of minerals, and for humans, longevity, immortality, and finally redemption". 2 Early modern European alchemical philosophy drew upon a number of classical, Islamic and medieval sources. $^{3}$ An Aristotelian understanding of nature, however, provided the basis for most alchemical reasoning. Aristotle argued that his four elements (fire, air, water, and earth) could be transmuted into each other. ${ }^{4}$ His De Generatione et Corruptione, a central text in any Renaissance education, attributed the changing nature of the world to this constant transmutation. ${ }^{5}$ The various form of metals resulted from differences in the purity of their components: sulphur and mercury. ${ }^{6}$ Eleventh century pseudo-Aristotelian texts such as the Secreta Secretorum, in which the philosopher supposedly revealed the secrets of medicine, astrology, alchemy and magic, furthered Aristotle's identification with alchemical concepts. ${ }^{7}$

Aristotle's physical theories provided the basis for England's strong medieval tradition of alchemical speculation. The thirteenth century English alchemist Roger Bacon (c.1214-1292) both pioneered the teaching of Aristotle's natural philosophy and wrote a number of alchemical texts, gaining wide prominence throughout Europe. ${ }^{8}$ It is notable that Bacon particularly emphasised the significance of Secretum Secretorum, which he considered one of Aristotle's most important works. ${ }^{9}$ Bacon compiled an influential new version, expanded with further astrological information. ${ }^{10}$ Bacon's work therefore demonstrates the link between alchemical and astrological thought, which he applied to

\footnotetext{
2 E.J. Sheppard, Ambix 17, 1970, pp 69-84 cited in William Brock, Chemistry, New York, 1993, p. 4.

${ }^{3}$ Eric Holmyard, Makers of Chemistry, Oxford, 1931.

${ }^{4}$ Urszula Szulakowska, The Alchemy of Light: Geometry and Optics in Late Renaissance Alchemical Illustration, Leiden, 2000, pp. 18-19.

${ }^{5}$ Ibid.

${ }^{6}$ Ibid.

7 Paolo Rossi, The Birth of Modern Science, Oxford, 2001, p. 18

${ }^{8}$ George Molland, 'Bacon, Roger (c.1214-1292?)', Oxford Dictionary of National Biography, Oxford, 2004 [http://www.oxforddnb.com/view/article/1008].

${ }^{9}$ Steven J. Williams, 'Roger Bacon and the Secret of Secrets' in Jeremiah Hackett (ed.), Roger Bacon \& the Sciences, Leiden, 1997, pp. 365-95.

${ }^{10}$ Ibid.
} 
other aspects of medieval knowledge, especially the supposedly scientific fields of mathematics and optics. ${ }^{11}$

In the fifteenth century, King Edward IV's (1442-1483) interest in alchemy was well known. He patronised several prominent alchemists including George Ripley (d. c.1490) and Thomas Norton (d. 1513). ${ }^{12}$ Ripley's The Compound of Alchemy, dedicated to King Edward, would remain hugely influential well into the seventeenth century. ${ }^{13}$ Relying on an Aristotelian understanding of nature to give credence to the reality of alchemical transmutation, this broadly focussed text covered not only the practical, but also the religious, moral and political applications of alchemy, demonstrating the already multifaceted nature of alchemical philosophy. ${ }^{14}$

The Renaissance intellectual movement of humanism-beginning in Italy in the late fifteenth century-increased the prominence of alchemical concepts and combined them with other forms of occult knowledge. ${ }^{15}$ Humanism placed great emphasis on the recovery of ancient knowledge, uncorrupted by false medieval interpretations and translations, hence validating the legitimacy of many ancient alchemical texts. ${ }^{16}$ Thus when Marsilio Ficino translated the Hermetic Corpus, an occult collection purportedly written by the mythical Egyptian priest Hermes Trismegistus, it became incredibly influential as a source of ancient knowledge. ${ }^{17}$ Alchemical knowledge carried with it a certain set of assumptions complementary to the Renaissance understanding of the world.

Alchemy's diverse background created an often contradictory set of beliefs, allowing proponents to shape their arguments to suit the prevailing philosophical and political orthodoxy. By associating alchemical ideas with ancient philosophers such as Aristotle, Plato and the supposed work of Trismegistus, Renaissance philosophers

\footnotetext{
${ }^{11} \mathrm{Ibid}$

12 Jonathan Hughes, Arthurian Myths and Alchemy: The Kingship of Edward IV, Stroud, 2002, pp. 102-04.

${ }_{13}$ Stanton J. Linden, The Alchemy Reader: From Hermes Trismegistus to Isaac Newton, Cambridge, 2003, p. 141.

${ }^{14}$ Urszula Szulakowska, 'The Pseudo-Lullian Origins of George Ripley's Maps and Routes as developed by Michael Maier', Cosmos, Vol. 9, 1993, p 177; Stanton J. Linden, The Alchemy Reader, p. 143.

${ }^{15}$ Frances Yates, The Occult Philosophy in the Elizabethan Age, London, 1979, reprinted 2003, pp.19-26.

${ }^{16}$ Ibid.

17 Ibid.
} 
associated alchemy with the humanist mission to regain ancient knowledge. Utilising the parallel between the alchemical unity of matter and the unity of God's creation, alchemical philosophers emphasised biblical support for their ideas. Paracelsus argued that Adam received the secrets of alchemy from God, which were then transmitted through the biblical patriarchs. ${ }^{18}$ Hence alchemists could claim to be the inheritors of a secret biblical art: they considered their work essentially a microcosm of the God's alchemical creation of the world. ${ }^{19}$

This study of occult correspondences-based on both biblical and classical evidence-linked alchemy together with the sometimes conflicting arts of Cabala and astrology. The occult art of Cabala correlated closely with alchemical ideas because of their shared assumptions about nature. Just as alchemy sought hidden knowledge through studying the unity of God's creation, Cabala sought divine revelation through an interpretation of Hebrew characters-God's original language. The early sixteenth century German alchemist Cornelius Agrippa linked alchemy with both astrology and Cabala. Influenced by Neo-Platonist ideas that emphasised metaphysical study and mathematics, Agrippa saw an understanding of how man, or the microcosm, mirrored the nature of the heavens, or macrocosm, as essential for all three arts. ${ }^{20}$ His most influential work, De Occulta Philosophia, integrated the study of occult astrological correspondences with both alchemical and cabalist practice. ${ }^{21}$

It would, however, be misleading to imply that there is a single framework for understanding sixteenth century alchemical beliefs and practices. Tara Nummedal has usefully outlined two distinct fields of alchemical practice in the sixteenth century. The first, philosophical alchemy, has been the focus of increased historical research since the 1960s. The examination of alchemical metaphors and parallels has helped historians

\footnotetext{
18 Raphael Patai, The Jewish Alchemists: A History and Source Book, Princeton, 1994, pp. 18-19.

${ }^{19}$ Ibid., p. 18.

${ }^{20}$ Yates, The Occult Philosophy, pp. 43-56.

${ }^{21}$ Ibid., pp. 52-55.
} 
explain why alchemy made sense in the sixteenth century. Occult philosophers such as Michael Maier, and to some extent the English alchemists John Dee, Richard Eden and Francis Thynne, sought to appeal to the philosophical interests of patrons such as Cecil. ${ }^{22}$ Whilst the character and emphasis of their beliefs varied greatly, they shared an understanding of alchemical knowledge as one element in a broader occult philosophy that sought to reveal all forms of hidden knowledge. Bruce Moran has argued that alchemical philosophy held particular appeal in Protestant courts, where "occult philosophy provided a strong ideological basis from which to legitimize their own separatist politics." 23

The second and, according to Nummedal, increasingly prevalent field in the sixteenth century, was commoditised practical alchemy. ${ }^{24}$ Whilst based on the same understanding of nature, many alchemists attempted to attract patronage by isolating their practices from the larger alchemical discourse. Rather than an esoteric quest for both spiritual and material perfection, they attempted to make "nature ripe by art" purely on a practical level..$^{25}$ Despite differences in ambition, utilitarian alchemists and occult philosophers shared a unified understanding of nature, which provided much of the appeal to their scholarly trained patrons. Both alchemical philosophy and practice implied a unified understanding of nature, in which each constituent part reflected the entire universe.

An analysis of Cecil's education is essential to determine the extent to which he shared this understanding of nature. Cecil attended St John's College at Cambridge University from 1535 until 1541, a time when the intellectual trends of the Renaissance and the religious transformations of the Reformation were causing enormous upheaval. Shortly after his arrival, King Henry VIII's imposition of royal religious supremacy led to the execution of John Fisher, the Bishop of Rochester, who had supervised the foundation of

22 Ibid.

${ }^{23}$ Moran, The Alchemical World, p. 25.

${ }^{24}$ Nummedal, Alchemy and Authority, pp. 10-13.

25 William Medley to William Cecil, 19 April 1572, TNA SP12/86/14. 
St John's College, and to whom many at the college professed loyalty. ${ }^{26}$ Alongside the religious Reformation, academic arguments over the interpretation of ancient texts epitomised the struggle between the entrenched scholasticism of Thomas Aquinas and Renaissance humanism's literary focus. ${ }^{27}$

Analysis of Cecil's education at Cambridge University is difficult. In contrast to his later life, we completely lack records of his experiences. Historians therefore discuss his Cambridge education in broader terms, focussing on the effect of political and religious turmoil on the young scholar. They highlight the influence of the Henrican suppression, both of those loyal to Rome and of radical Protestants, on Cecil's later political and religious views. This marginalises the Aristotelian intellectual tradition that shaped him. ${ }^{28}$ Traditionally, historians have described Tudor Cambridge and Oxford as "predominantly grammarian and unscientific [in] character", but Mordechai Feingold has catalogued the occult tradition among English university graduates, arguing that "until the middle of the seventeenth century the occult tradition was essentially an intellectual tradition". ${ }^{29}$ More recently Stephen Alford has emphasised the influence of the new humanism on the university curriculum. ${ }^{30}$ Alford described how successful, ambitious young humanists at St John's, such as John Cheke, triggered a re-examination of many aspects of university learning, centring on a controversial new pronunciation of Greek. ${ }^{31}$

Cecil's education may have reflected the growing influence of humanist philosophy, nevertheless "Aristotle was still The Philosopher, but it was a less scholastic Aristotle". ${ }^{32}$ Whilst the Henrican injunctions had introduced other philosophers such as Philip Melanchthon, the aim was not to replace Aristotle in the curriculum, but to improve the

\footnotetext{
26 Read, Secretary Cecil, pp. 26-27.

27 Alford, Burghley, p. 18.

${ }^{28}$ Mordechai Feingold, 'The Occult Tradition in the English Universities of the Renaissance: a Reassessment' in Brian Vickers (ed.), Occult and Scientific Mentalities in the Renaissance, Cambridge, 1986, p. 74.

${ }^{29}$ Ibid., p. 89; Frances Yates, Lull \& Bruno, London, 1982, p. 250.

30 Alford, Burghley, pp. 17-19.

${ }^{31}$ Charles Nauert, Humanism and the Culture of Renaissance Europe, Cambridge, 1995, p. 187.

32 Damian Riehl Leader, A History of the University of Cambridge, Volume 1: The University to 1546, Cambridge, 1988, p. 349.
} 
accuracy of the Aristotelian texts. ${ }^{33}$ The majority of the curriculum still comprised of Aristotelian study and humanist critiques of scholasticism appealed to the authority of Aristotle. $^{34}$ For scholars at Tudor Cambridge, the study of alchemy and the occult remained a natural development from an Aristotelian education.

Mathematics, increasingly the target of scholarly interest, was often associated with the occult, to the extent that alchemical works were often categorised as mathematical. The official mathematical curriculum also included elements of astrology. ${ }^{35}$ Renaissance humanists, influenced by Agrippa, emphasised the connection between astrological influences and alchemical processes, because propitious astrological forces were required to bring about alchemical changes. ${ }^{36}$ Cambridge trained occult philosophers such as John Dee would therefore attempt to integrate astrology and alchemy within a natural philosophy that demonstrated the unity of creation through occult influences and correspondences. ${ }^{37}$ Cambridge graduates thus perceived alchemy within this unified worldview, both as a physical process and as an inner transformation linked to the perfection of the external world. These changes corresponded to the occult effects of the macrocosm: the universe, on the microcosm: man. ${ }^{38}$ A Renaissance education encouraged intellectuals to seek an integrated knowledge of nature, which for many included alchemy.

Records suggest that the English universities shared the state's official attitude towards the pursuit of alchemical knowledge. Private study and practice was tolerated, sometimes even subtly encouraged, as long as it did not result in the illegal debasement of coinage. $^{39}$ University officials were clearly aware of the interest in the occult sciences

\footnotetext{
33 Ibid., p. 332.

${ }^{34}$ W. Keith Percival, 'Changes in the Approach to Language', in Norman Kretzmann, Anthony Kenny and Jan Pinborg (eds.), The Cambridge History of Later Medieval Philosophy, Cambridge, 1982, p. 813.

35 Feingold, 'The Occult Tradition', pp. 78-79.

${ }^{36}$ William R. Newman and Anthony Grafton, 'Introduction: The Problematic Status of Astrology and Alchemy in Premodern Europe', in Newman and Grafton (eds.), Secrets of Nature, pp. 24-25.

${ }^{37}$ Glyn Parry, The Arch-Conjuror of England: John Dee and Magic at the Courts of Renaissance Europe, Yale University Press, New Haven, Forthcoming 2010.

${ }^{38}$ Moran, The Alchemical World, p. 25.

${ }^{39}$ Charles B. Schmitt, John Case and Aristotelianism in Renaissance England, Montreal, 1983, pp. 118-19.
} 
among students and teachers, with a number of related topics approved for formal university debates, including a debate on the possibility of alchemical transmutation. ${ }^{40}$

Historians have largely ignored those aspects of university learning outside the official curriculum and pursued through private discussion. The careers of Cecil's friends and fellow scholars suggest these encompassed elements of the alchemical and occult learning advocated by humanist scholars such as Cornelius Agrippa. Alford argues that Cecil shared the interests of "a club of young, energetic and clever men who loved scholarship and learned from one another" and that this gave him "friends for life". However, he fails to explore the implication of many of these friends' fascination, and even obsession, with both the philosophy and practice of alchemy. It seems unlikely that Cecil shared so much with his intellectual contemporaries but stopped short of alchemy. In fact, the letters Cecil later exchanged with his former classmates and tutors clearly reflected their shared enthusiasm for alchemy.

Cecil had a close association with both of the leading lights of the Cambridge humanist movements, John Cheke and Thomas Smith. Students and later lecturers at Cambridge, Cheke and Smith had a devoted following, and in championing the new, more authentic, but controversial, pronunciation of Greek, they exemplified the new humanist attitude towards knowledge. ${ }^{42}$ Less evident from the historiography, however, is both men's interest in alchemy.

Initially acting as Cecil's tutor, John Cheke became a close friend of his student. Such was Cecil's familiarity with the Cheke family, that in 1541 he made the uncharacteristically impulsive decision to marry Cheke's younger sister, Mary. ${ }^{43}$ The family were not wealthy or influential and, to Cecil's father's mind at least, it was a disastrously

${ }^{40}$ Feingold, 'The Occult Tradition', p. 78.

41 Alford, Burghley, p. 18.

${ }^{42}$ Nauert, Humanism and the Culture, p. 187.

${ }^{43}$ Read, Mr Secretary, p. 27. 
short-sighted match. ${ }^{44}$ There is evidence that Cheke also introduced Cecil to alchemical concepts. In 1562 Richard Eden, informing Cecil of the success of his latest alchemical experiments, was

sure, that if the floure of learning of our tyme, and sumtyme Tutor and brother in lawe unto your L[ordship], Mr Cheeke, had seene any of these two secreats, he wolde greatly have rejoysed: As I knowe the divine sparke of knowledge that is in your L[ordship] partely receaved of hym, wyll move you to doo the like ${ }^{45}$

Cecil's marriage with Mary Cheke was short lived. Mary died in 1543 shortly after giving birth to Cecil's first son, Thomas. ${ }^{46}$ Cecil, who left university in 1541, without taking a degree, stayed in close contact with his former brother in law. Both men moved from Cambridge to the Court in London and both acted as secretaries to King Edward VI. ${ }^{47}$ Cheke, however, did not live to see the accession of Queen Elizabeth. He died in 1557, shortly after being kidnapped during his exile in the Netherlands and forcibly converted to Catholicism. $^{48}$

Cecil's other tutor Thomas Smith also importantly shaped Cecil's intellectual development, and they remained in close contact long after leaving Cambridge. The second son of a poor Essex sheep farmer, Smith rose to the prestigious rank of Regis Professor on the back of a precocious intellect and enormous ambition. ${ }^{49}$ As an acknowledged leader of the humanist intellectuals, Smith was an enormously influential figure at Cambridge. While Smith's later political career would never match the heights of his intellectual reputation, he did hold a number of important positions within the Edwardian and Elizabethan

\footnotetext{
44 Ibid., p.29.

45 Richard Eden to Cecil, 1 August 1562, BL, Lansdowne, Vol. 101, no. 5.

${ }^{46}$ Read, Mr Secretary, p. 29.

47 Alan Bryson, 'Cheke, Sir John (1514-1557)', Oxford Dictionary of National Biography, Oxford, Sept 2004; online edn, Oct 2008 [http://www.oxforddnb.com/view/article/5211].

${ }^{48}$ Ibid.

${ }^{49}$ Dewar, Sir Thomas Smith, pp. 9-25.
} 
governments. Cecil made sure his friend succeeded him as Principal Secretary to Elizabeth, although Smith did not retain the influence on policy that his predecessor enjoyed. ${ }^{50}$

Described as being of "singular learnynge in all sciences" and "the flower of the University of Cambridge", Smith maintained an almost obsessive interest in alchemy, building alchemical laboratories in both his London and Essex homes. ${ }^{51}$ However, Smith's alchemical interests have been ignored, down played and derided by subsequent historians. Their failure to appreciate that his understanding of the world necessitated belief in alchemy has given them a conflicted historical assessment of Smith. Mary Dewer's biography of Smith allowed that his “chemical experiments with his precious 'stills' were an abiding interest, at times almost a ludicrous preoccupation in later years". ${ }^{52}$ While this assessment fit her view of Smith as "mercurial in temperament, rash and impetuous", Dewar struggled to relate his alchemical interests to his more scholarly enquiries. ${ }^{53}$ His correspondence with another Cambridge educated scholar, Richard Eden, reveals their common alchemical interests. Smith replied rhetorically to an offer of an alchemical demonstration, asking

who can be more desirous to see the unlooked for and incredible privities of nature than I am and have ever been. Yet that there can by that art be made and brought to pass most strange, wondrous and incredible things, both have I had experience myself and I have read much more. ${ }^{54}$

Smith's interest in alchemy was partly inspired by his chronic ill health. He claimed that "for my health, I have found more help in [alchemy] than in all the physic hitherto in my life essayed". ${ }^{5}$

Smith's library provides further evidence of the occult and alchemical knowledge he encountered and taught while at Cambridge. A 1566 catalogue numbered his collection at around four hundred works, more than the holdings of either Cambridge or Oxford

\footnotetext{
50 Ibid., pp. 171-84.

51 Preface by Richard Eden to Martin Cortez, The Art of Navigation, Richard Eden (trans.), London, 1561, p. viii; Dewar, Sir Thomas Smith, p. 15.

52 Dewar, Sir Thomas Smith, p. 15.

53 Ibid., p. 6.

54 Thomas Smith to Richard Eden, 9 March 1572, TNA, SP 70/146 f.56v.

${ }^{55}$ Ibid.
} 
University in the period. ${ }^{56}$ A high proportion of the books related to history, theology or medicine, all preoccupations of the Elizabethan elite, whilst others reflected his scholarly interest in law. Alongside Elizabethan best sellers such as his friend Richard Eden's The Art of Navigation (1561), were numerous books discussing alchemy, astrology, chemical medicine, and the occult. ${ }^{57}$

The presence of works such as Cornelius Agrippa's De Occulta Philosophia (1533) in Smith's library indicates the particular mix of interests common amongst Elizabethan intellectuals. ${ }^{58}$ Popular amongst many university trained scholars, including Smith's fellow Cambridge graduate John Dee, Agrippa's book dealt primarily with the occult correspondences of cabalistic cosmogony. ${ }^{59}$ Also present was the supposedly Rosicrucian collection De Alchimia opuscula complura veterum philosophorum (1550), dedicated to the chemical physician Paracelsus, which included alchemical works attributed to Aristotle, alongside tracts by alchemical authorities such as Raymond Lull. ${ }^{60}$ Works such as these cemented the association of humanist attempts to restore ancient knowledge with both philosophical and practical alchemy. Smith's possession of Georgius Agricola's influential metallurgical work De Re Metallica (1556) is suggestive of the scholar turned statesman's instinct to apply alchemical knowledge to financially beneficial practical endeavours. ${ }^{61}$ Long after Smith's death in 1577 the eminent Elizabethan scholar Gabriel Harvey wrote to Cecil's son Robert, paying tribute to "the true Chymique without imposture which I learned from Sir Thomas Smith not to condemn". ${ }^{2}$ It is likely Smith, as Cecil's tutor and friend, taught the future Lord Treasurer the same distinction between true and counterfeit alchemy.

\footnotetext{
${ }^{56}$ Smith's Library Catalogue printed in John Strype, The Life of the Learned Sir Thomas Smith, Kt. D.C.L., Principal Secretary of State to King Edward the Sixth, and Queen Elizabeth, London, 1698, reprinted 1820, pp. $274-$ 81; David Stam, International Dictionary of Library Histories, Vol. 1, Chicago, 2001, pp. 810, 868.

57 Ibid., p. 279.

58 Ibid., p. 278.

${ }_{59}$ Julian Roberts and Andrew G. Watson, John Dee's Library Catalogue, London, 1990, p. 69; Yates, The Occult Philosophy, pp. 43-56.

${ }^{60}$ Strype, The Life of the Learned Sir Thomas Smith, p. 279.

${ }^{61}$ Ibid., p. 278.

${ }^{62}$ Roberts, R. A. (ed.), CMS: 1598, London, 1899, p. 160.
} 
Unfortunately we can only speculate on the degree to which Cecil's own library resembled that of his colleague and friend. Pamela and David Selwyn suggest that it would have dwarfed Smith's library in both size and scope. ${ }^{63}$ Intellectual inclination and means allowed Cecil to take full advantage of the burgeoning European print industry. By the time of his death, Cecil had accumulated what was likely one of the largest libraries of both printed and manuscript material in England. ${ }^{64}$ The books Cecil so voraciously collected would provide compelling evidence as to his intellectual interests. Despite this, no serious attempts have been made to reconstruct the contents of Cecil's library.

The dispersal of Cecil's books in the century following his death has made such a task extremely difficult. According to Cecil's descendant Robert Gascoyne-Cecil, 5th Marquess of Salisbury, Cecil left the vast majority of his books to his elder son Thomas. ${ }^{65}$ It seems that the library was auctioned off in 1687 after the death of Robert Bruce, $1^{\text {st }}$ Earl of Ailesbury, who inherited the collection through his wife, Cecil's great-greatgranddaughter. ${ }^{66}$ Although the auction purported to contain "the main part of the Library of that Famous Secretary William Cecil, Lord Burghley", a large proportion of the books listed were published after Cecil's death. ${ }^{67}$ These and likely some of the earlier works were from Ailesbury's own library. However, as Ailesbury assembled his library in the years after the Restoration in 1660 , it is not unreasonable to assume that a considerable proportion of the approximately 1,700 books published before 1598 had been part of Cecil's library. ${ }^{68}$ He certainly owned most of the listed manuscripts. ${ }^{69}$ Caroline Bowden therefore argues that the sixteenth-century books in the sale catalogue allow us to draw

\footnotetext{
${ }^{63}$ Palmela Selwyn and David Selwyn, “'The profession of a gentleman”: Books for the Gentry and the Nobility (c. 1560 to 1640), in Elisabeth Leedham-Green and Teresa Webber (eds.), The Cambridge History of Libraries in Britain and Ireland, Cambridge, 2006, pp. 501-02.

64 Ibid., p. 502.

${ }^{65}$ Robert Gascoyne-Cecil, 'The Library at Hatfield House, Hertfordshire', The Library, Vol. 18, No. 2, 1963 , p. 86.

${ }^{66}$ T. F. Henderson, 'Bruce, Robert, second earl of Elgin and first earl of Ailesbury (bap. 1626, d. 1685)', rev.

Victor Stater, Oxford Dictionary of National Biography, Oxford, 2004; online edn, May 2009

[http://www.oxforddnb.com/view/article/3757].

${ }^{67}$ Anon, Bibliotheca Illustrissive Catalogus Variorum Librorum, London, 1687, p. i.

${ }^{68}$ Henderson, 'Bruce, Robert'.

${ }^{69}$ Sears Jayne, Library Catalogues of the English Renaissance, Godalming, 1983, p. 132.
} 
some tentative conclusions about Cecil's holdings, "although the lack of evidence of provenance makes any comparisons suggestive rather than substantive". ${ }^{70}$

The contents of the catalogue include a number of works that, if they were part of Cecil's library, reveal a significant interest in magic, astrology and especially alchemical medicine. Included are Paracelsus' Chirurgia Magna (1573), John Dee's Monas Hieroglyphica (1564), Marsilo Fincino's De Vita Libri Tres (1550), along with works by the alchemists Ramon Lull and Arnold de Villa Nova. ${ }^{71}$ The range of books in the Ailesbury sale certainly resembles the smaller number that remained at Cecil's house on the Strand. According to Pamela and David Selwyn a significant proportion of this library's approximately 1,400 works dated from before Robert Cecil's death in 1612 relate to natural philosophy including "herbals, gardening and medical books, astronomy and meteorology, agriculture and mineralogy" ${ }^{72}$

Mildred Cooke, Cecil's second wife and daughter of the humanist scholar Sir Anthony Cooke, maintained a small private library. Caroline Bowden's reassembly of the library's contents corroborates these tentative conclusions. Most of these books would have likely originated from Cecil's own library, and he is known to have shared the intellectual interests of his wife. Lady Cecil's library included Euclid's Elements of Geometry (1579), with its famous preface by John Dee, praising the applications of mathematics in astrology and alchemy. ${ }^{73}$ Medical works were also prominent. Along with the classical Galenist texts, Lady Cecil also owned an edition of the Paracelsian Jean Fernel's huge medical compendium Medicina (1554)..$^{74}$ Recent historians of Renaissance magic have identified Fernel as "one of the most important figures in the history of Renaissance

\footnotetext{
${ }^{70}$ Caroline Bowden, 'The Library of Mildred Cooke Cecil, Lady Burghley' The Library, Vol. 6. No. 1, 2005, p. 18.

71 Anon, Bibliotheca Illustrissive Catalogus V ariorum Librorum, London, 1687.

72 Selwyn and Selwyn, 'The profession of a gentleman', pp. 510-11.

${ }^{73}$ Bowden, 'The Library of Mildred Cooke', p. 27.

${ }^{74}$ Ibid.
} 
occultism". 75 Bowden sees Medicina as "an unusual choice for a layperson not intending to practise medicine professionally" ${ }^{76}$ Perhaps Lady Cecil shared her husband's fixation with herbal and chemical medicines, like other gentle ladies such as Grace Mildmay, who used chemical treatments in her own medical practice. ${ }^{77}$

Many supplicants seeking Cecil's patronage knew of his ongoing fascination with both the philosophical and practical implications of alchemy. Often university educated, they shared his understanding of nature and were exposed to a similar range of humanist and Aristotelian concepts. An appraisal of Cecil's relationship with two fellow Cambridge scholars, John Dee and Richard Eden, reveals more about a common fascination with alchemy developed through a common education. Examining the alchemist and herald Francis Thynne further demonstrates that Cecil's clients both knew of and utilised his interest in alchemical philosophical knowledge.

Very little has been written on Cecil's problematic relationship with the most famous Elizabethan disciple of occult philosophy, and fellow Cambridge alumni, John Dee. Historians have generally argued that while Cecil found Dee politically useful at times, he was generally disdainful of Dee's particular brand of occult theory. ${ }^{78}$ Dee certainly found Cecil an intimidating figure, in 1582 recording a dream in which he

was deade and afterward my bowels wer taken out I walked and talked with diverse, and among other with the Lord Tresorer [Cecil] who was com to my howse to burn my bokes when I was dead, and thought he loked sourely on me. ${ }^{79}$

In many ways Dee embodied the ostentatious knowledge that Stephen Pumfrey and Frances Dawbarn have argued did not interest Cecil. ${ }^{80}$ This thesis maintains that whilst

\footnotetext{
75 John M. Forrester, 'Tradition and Reform: Jean Fernel's Physiology (1567)', in Jean Fernel, John M. Forrester (ed.), The Physiologia of Jean Fernel (1567), John M. Forrester (trans.),Philadelphia, 2003, p. 3.

${ }^{76}$ Bowden, 'The Library of Mildred Cooke Cecil', p. 16.

${ }^{77}$ Linda Pollock, With Faith and Physic: The Life of a Tudor Gentlewoman: Lady Grace Mildmay 1552-1620, London, 1993, pp. 96-98.

78 Peter French, John Dee: the World of an Elizabethan Magus, London, 1972, pp.194-197.

${ }^{79}$ John Dee, James Halliwell (ed.), The Private Diary of Dr. John Dee, London, 1842, pp 17-18.

${ }^{80}$ Pumfrey and Dawbarn, 'Science and Patronage in England', p. 160.
} 
Cecil tended to favour more practical aspects of alchemical patronage, he was more often alienated by Dee's religious ambiguity and lack of political judgement.

While Dee matriculated at St. John's shortly after Cecil had left, the extent of his association with Cecil's academic circle is unclear. Although both attended St. John's College, Dee associated largely with conservative Catholic scholars and was out of step with the more reformist instincts of the group surrounding Cheke and Smith. ${ }^{81}$ Dee's interest in alchemy and occultism certainly developed out of his Cambridge education. According to his book on occult symbolism, Monas Hieroglyphica (1564), Dee started his study of alchemy during his first year at Cambridge. ${ }^{82}$ Nevertheless, Dee's biographers have argued that he was somehow out of place at Cambridge; that scholars like Cecil, Smith, and Cheke were concerned only with the study of logic and discourse rather than alchemical secrets. ${ }^{83}$ However, in arguing that there is no indication that Cambridge introduced Dee to any of his alchemical, occult or hermetical ideas in a "formal way", Nicholas Clulee inadvertently made an important point. ${ }^{84}$ Dee provides the best example of the way in which the informal promulgation of alchemical and occult knowledge at English universities, especially Cambridge, influenced the educated classes of Elizabethan England. Dee and many others would take advantage of these shared obsessions in order to attract lucrative patronage. Appeals for Cecil that demonstrate the author's alchemy expertise are important because they demonstrate an awareness amongst supplicants that they could attract Cecil's patronage by appealing to his fascination with alchemy.

After studying at the conservatively Catholic Louvain University, Dee received some favour under Edward VI. ${ }^{85}$ Dee's 1592 autobiographical tract, Compendious Rehearsal, all too often taken at face value by historians, implies that his advancement to the Court

\footnotetext{
81 Parry, The Arch-Conjuror of England.

82 Feingold, 'The Occult Tradition', p. 80.

${ }^{83}$ French, John Dee, p. 22; Nicholas Clulee, John Dee's Natural Philosophy: Between Science and Religion, London, 1988, pp. 22-28.

${ }^{84}$ Nicholas Clulee, ‘Astrology, Magic, and Optics: Facets of John Dee's Early Natural Philosophy', in Brian Levack (ed.), Renaissance Magic, New York, 1992, p. 7.

85 Parry, The Arch-Conjuror of England.
} 
came easily, as a result of his connection to Cambridge scholars such as Cheke. ${ }^{86}$ However, Glyn Parry argues that Dee overstated the strength of his relationship with St. John's scholars such as Cheke and Cecil. ${ }^{87}$ Rather his favour came primarily from patronage by John Dudley, the Earl of Warwick and soon to be Duke of Northumberland, a connection that by 1592 had become politically embarrassing. On 12 December 1551 Dee did gain an interview with Cecil, at this time Edward's junior secretary, who left Dee sufficiently impressed to "remember whereof his discourse with me then" over forty years later. ${ }^{88}$ Dee's account gives the distinct impression that this was their first encounter. Whilst Dee's knowledge and astrological skills were valued enough to earned him a $f^{25}$ pension and the Rectory of Upton-upon Severn, he remained a marginal figure at the Edwardian Court. ${ }^{89}$

If Dee managed to cultivate a relationship with Cecil under Edward, his actions under Queen Mary left it thoroughly, and perhaps permanently, undermined. Recent research by Glyn Parry has revealed that, threatened with the loss of his Rectory, Dee agreed to be ordained as a Catholic priest. ${ }^{90}$ He then became chaplain to the Bishop of London, Edmund Bonner, further demonstrating his Catholic orthodoxy. Although in some Protestant circles this would have irredeemably damaged Dee's reputation, he retained some favour with the religiously moderate Princess Elizabeth, who at this time was herself partaking in the Catholic Mass. ${ }^{11}$ In May 1555, with Mary in the midst of a false pregnancy, the exposed Elizabeth employed Dee to divine her political future through magical means. ${ }^{92}$ Unfortunately for Dee, he was betrayed to the Privy Council and arrested. After possibly being tortured, Dee returned to Bonner's household, where his interrogation of a number of Protestant martyrs, recorded in early editions of John Foxe's

\footnotetext{
${ }^{86}$ John Dee, 'The Compendious Rehearsal', in James Crossley (ed.), Autobiographical Tracts of Dr. John Dee, Manchester, 1851.

87 Parry, The Arch-Conjuror of England.

${ }^{88}$ Dee, 'The Compendious Rehearsal', p. 12.

${ }^{89}$ Parry, The Arch-Conjuror of England.

${ }^{90}$ Glyn Parry, 'John Dee and the Elizabethan British Empire in its European Context', The Historical Journal, Vol. 49, No. 3, 2006, p. 645.

${ }^{91}$ Alison Plowden, Danger to Elizabeth: The Catholics Under Elizabeth I, London, 1973, p. 23.

92 Glyn Parry, 'John Dee and the Elizabethan British Empire', p. 645.
} 
Actes and Monuments (1563), "fatally compromised his reputation amongst Protestants". 93 Whilst Dee rehabilitated himself in the early years of Elizabeth's reign, and succeeded in concealing his actions under Mary, Cecil had a long memory. Cecil would show interest and even enthusiasm for the more practical aspects of Dee's alchemical endeavours, but did not exhibit the same amity as he held for the rest of his Cambridge colleagues.

During Elizabeth's reign Dee, like so many others, found that Cecil stood as the gatekeeper to royal patronage, and that occult philosophy provided a key to open that gate. In 1563 Dee, in Antwerp arranging the printing of his cabalistic work Monas Hieroglyphica, wrote to Cecil reporting on his progress. ${ }^{94}$ Dee appealed especially to Cecil "among so many other in place of high honor and governance" because of his "approved wisdome" and "naturall zeale". ${ }^{95}$ His search to accumulate divine knowledge had led him to a work "for which many a lerned man hath longe sowght, and dayly yet doth seeke": the German occultist Johannes Trithemius' (1462-1516) magical and cryptographic book Steganographia (c.1499). ${ }^{96}$ It is significant that Dee thought that "the name [of Trithemius] therof to you is not unknowne". ${ }^{97}$ Trithemius had a particularly dark reputation for communicating with evil spirits, a notoriety reinforced by both Martin Luther and Philipp Melanchthon. ${ }^{98}$

Steganographia, prefaced with a theoretical defence of the occult arts, contained a complex system of magical spirit communication and described Pythagorean numerology as the key to alchemy. ${ }^{99}$ As the work has later been identified as primarily cryptography disguised as magic, most historians have assumed that Dee was appealing to Cecil's interest in disguising his communications. ${ }^{100}$ However, the true nature of the first two books of Steganographia remained unknown until the publication of the decryption key in 1606, with

\footnotetext{
${ }^{93}$ Ibid.

${ }^{94}$ John Dee to Cecil, 16 February 1563, TNA, SP 12/27/63.

95 Ibid.

${ }^{96}$ Ibid.

${ }^{97}$ Ibid.

${ }_{98}$ Noel L. Bran, Trithemius and Magical Theology: a Chapter in the Controversy over Occult Studies in Early Modern

Europe, Albany, 1999, pp. 165-66.

${ }^{99}$ Ibid., p. 178.

${ }^{100}$ Charlotte Fell Smith, John Dee 1527 to 1608, London, 1909, p. 21.
} 
the third book defying deciphering until $1998 .{ }^{101}$ In this context it is remarkable that Dee, having already copied out the first half, considered Steganographia "A boke for your honor, or a prince, so meet, so nedefull and comodious, as is humayne knowledg, none can be meeter, or more behofeful". ${ }^{102}$ Dee informed Cecil that if he was allowed more time in Antwerp, he would in turn present Cecil with a copy of the book. He was confident that a man of Cecil's "wisdome and honorable zeale, toward the ... wonderfull devine and secret sciences" would appreciate such an esoteric gift. ${ }^{103}$

The next extant letter from Dee to Cecil is dated a decade later, on 3 October 1574. They had clearly been in frequent contact in the interim, and Dee refers to having recently been "very favourably used" by Cecil. ${ }^{104}$ Dee expressed his disappointment that the “gracious good favour, that I was persuaded the queen's most excellent majesty did bear unto me" had not persuaded her to increase his income. ${ }^{105}$ Indeed Dee claimed that if it were not for Cecil's "helping hand", his overseas travels would have been impossible, once again raising questions about the nature of Cecil and Dee's relationship. ${ }^{106}$ Possibly Dee was referring to his 1571 journey to Lorraine, where he acquired equipment for his alchemical experiments for Sir Henry and Lady Mary Sidney, close associates of Cecil. ${ }^{107}$ Cecil may have been responsible for Dee's generous passport and escort in the form of the Chancery clerk, Thomas Powle ${ }^{108}$ The purpose of Dee's 1574 letter was to request a licence to find treasure by magical means, illegal without a royal licence since $1542 .{ }^{109}$ In exchange for the profits of his searches Dee requested a massive annual pension of $f^{200} .^{110}$ Cecil's good will clearly did not stretch that far, as Dee remained in relative poverty.

\footnotetext{
101 Jim Reeds, 'Solved: The Ciphers in Book III of Trithemius's Steganographia', Cryptologia, Vol. 22, No. 4, 1998, pp. 291-317.

102 Dee to Cecil, SP 12/27/63.

103 Ibid.

${ }^{104}$ Dee to Cecil, 3 October 1574, BL, Lansdowne Vol.19 No.38.

105 Ibid.

106 Ibid.

107 Parry, The Arch-Conjuror of England.

108 Ibid.

${ }^{109}$ Dee to Cecil, BL, Lansdowne Vol.19 No.38; Thomas, Religion and the Decline of Magic, pp. 280-81.

${ }^{110} f_{2} 200$ was approximately ten times the average annual wage for a skilled craftsman. See TNA, 'Currency Converter', [http://www.nationalarchives.gov.uk/currency]; Dee to Cecil, Lansdowne Vol.19 No.38.
} 
Dee and Cecil's relationship over the following decade revolved primarily around Dee's justification of Elizabeth's right to a both Atlantic and European empire, and his proposal to reform the calendar to a more accurate system, similar to the Gregorian calendar imposed in Catholic Europe in 1582-83. ${ }^{111}$ Whilst Cecil, cautious about any military involvement in Europe, may not have welcomed Dee's grand images of an Arthurian British Empire, he did support the implementation of Dee's reformed calendar prior its veto by Elizabeth's bishops. ${ }^{112}$ Cecil's interactions with Dee would remain on this more mundane level until the mid 1580s, when the alchemical success of Dee's former assistant Edward Kelley, as dealt with in chapter three, became a vital matter of government interest.

Whilst Dee certainly demonstrates the prevalence of occult thought within the Elizabethan mindset, the alchemical obsessions of Richard Eden provide perhaps a better indication of the intellectual milieu of Cecil's education. Eden was one of the Cambridge men amongst whom Cecil "always moved naturally and easily", as he "spoke their language, understood their point of view, and promoted their interests". ${ }^{113}$ Eden, therefore, provides an ideal example of the mixture of occult interests which shaped the outlook of mid sixteenth century Cambridge. It is therefore useful to examine his career at some length.

Eden remains unexamined in the context of his fellow Cambridge scholars. Winthrop Hudson's analysis of the group which surrounded Cecil, Cheke and Smith in The Cambridge Connection (1980) fails to mention Eden. ${ }^{114}$ Eden is also conspicuously absent

111 Parry, The Arch-Conjuror of England.

112 Parry, The Arch-Conjuror of England.

113 Read, Mr Secretary Cecil, p. 30.

114 Winthrop S. Hundon, Cambridge Connection and the Elizabethan Settlement of 1559, Durham, 1980. 
from Mordechai Feingold's examination of the occult tradition in English universities, which is otherwise comprehensive in its cataloguing of occultists in the university system. ${ }^{115}$

Those historians that have examined Eden have focussed on his importance as a translator and promoter of colonial projects. ${ }^{116}$ Certainly Eden's translations of Spanish accounts of the New World, such as The Decades of the Newe Worlde or West India (1555), were enormously influential, especially on the work of the later sixteenth century geographer Richard Hakluyt. ${ }^{117}$ Early studies such as Edward Arber's, 'The Life and Labours of Richard Eden, Scholar, and Man of Science, [?1521]-1576' (1885), provided only a chronology of Eden's life, attempting little historical analysis. ${ }^{118}$

Since C. J. Kitching's 1971 account of Eden's alchemical experiments with Richard Whalley, there has been some attempt to explore Eden's alchemical beliefs. ${ }^{119}$ David Gwyn's article 'Richard Eden: Cosmographer and Alchemist' (1984) remains the most in depth study of Eden. ${ }^{120}$ While he examines Eden's interest in alchemy, Gwyn misunderstands some of his letters and treats Eden's alchemical obsession as separate from his cosmological interests. More recently Edmund Valentine Campos has provided a thought provoking examination of the metallurgical metaphors Eden employed in describing the New World, such as comparing the signs of inhabitable land to the tokens suggesting mineral deposits. ${ }^{121}$ However, Campos' interpretation of Eden's account of an alchemical experiment as a "coded dream of colonial desire", couched in alchemical

\footnotetext{
115 This may be due to his omission from Athenae Cantabrigienses 1500-1585, appearing instead in the 15861609 volume. See Charles Henry Cooper and Thomas Cooper, Athenae Cantabrigienses Vols. 1\&2, Cambridge, $1858,1861$.

116 See Andrew Hadfield 'Peter Martyr, Richard Eden and the New World: Reading, Experience and Translation', Connotations, Vol. 5, 1995/6, pp. 1-22.

117 Richard Eden, The Decades of the Newe Worlde or West India, London, 1555; Andrew Hadfield, 'Eden, Richard (c.1520-1576)', Oxford Dictionary of National Biography, Oxford, Sept 2004; online edn, Jan 2008 [http://www.oxforddnb.com/view/article/8454].

118 Edward Arber, 'The Life and Labours of Richard Eden, Scholar, and Man of Science', in Edward Arber (ed.) The First Three English Books on America, Birmingham, 1885, pp. xxxvii-xlviii.

${ }^{119}$ C. J. Kitching, 'Alchemy in the Reign of Edward VI: an Episode in the Career of Richard Whalley and Richard Eden', Bulletin of the Institute of Historical Research, Vol. 44, 1971, pp. 308-315.

${ }^{120}$ David Gwyn, 'Richard Eden Cosmographer and Alchemist', The Sixteenth Century Journal, Vol. 15, No. 1, 1984, pp. 13-34.

${ }^{121}$ Edmund Valentine Campos, 'West of Eden: American Gold, Spanish Greed, and the Discourses of English Imperialism', in Margaret Rich Greer, Walter Mignolo, Maureen Quilligan (eds.), Rereading the Black Legend: the Discourses of Religious and Racial Difference in the Renaissance Empires, Chicago, 2007, pp. 247-269.
} 
symbolism, seems tenuous. It ignores both the other alchemical references within the letter, and the experiment's resemblance to that of the seventeenth century alchemist known as Eirenaeus Philalethes. ${ }^{122}$

Eden, born around 1520 into a family of East Anglian cloth merchants, seems to have intended to join the church, having been elected to a foundation scholarship, intended for aspirants to holy orders, at Christ's College, Cambridge in $1535 .{ }^{123}$ Moving to Queens' College in 1537, Eden's tutor Thomas Smith introduced him to his circle of fellow humanist scholars, including Cecil, Cheke, Roger Ascham and Gabriel Harvey. ${ }^{124}$ Eden's lifelong obsession with alchemical texts and medicines attests to the intellectual interests of this group. For Eden alchemy formed an integral part of his more general effort to amass rare knowledge, complementing in the natural realm his interest in global cosmography, what today we would call geography. After graduating with a Master of Arts degree in 1544, Eden moved to a position at the Treasury "until the King's death; who, when dying, did not forget him, but assigned to him the office of the distillery". ${ }^{25}$ While the new Lord Protector, the Duke of Somerset, assigned the post to someone else, Eden's expertise in distillation, then considered an alchemical technique, had clearly become well known. ${ }^{126}$

The alchemical project of Eden and Richard Whalley serves as a good example of the shared alchemical interests of many Cambridge alumni. Whalley, who had also attended St. John's College, rose to some prominence as a client of Somerset during his time as Lord Protector. ${ }^{127}$ While usually accorded little significance by historians, Whalley did make useful contacts as chamberlain of the Duke's household, forging a close association with

\footnotetext{
122 Eirenaeus Philalethes, Secrets Reveal'd: or, an Open Entrance to the Shut-Palace of the King, London, 1669, p. 28.

${ }^{123}$ Hadfield, 'Eden, Richard'.

124 Ibid.

125 Arber, 'The Life and Labours', p. xlv.

126 Ibid.

127 Alan Bryson, 'Whalley, Richard (1498/9-1583)', Oxford Dictionary of National Biography, Oxford, Sept 2004; online edn, Jan 2008 [http://www.oxforddnb.com/view/article/29161].
} 
Cecil, by this point an advisor to the Protector. ${ }^{128}$ With the fall of Somerset in late 1549, Whalley, like many of the Duke's supporters, suffered a drastic change of fortunes. ${ }^{129}$ His links to Cecil, however, gave him some influence in government. John Dudley, Earl of Warwick, effectively head of government as Lord President of the Council, turned to Whalley in order to forge ties with Cecil. ${ }^{130}$ It was during Somerset's time in the Tower (1549-50) that Whalley employed Richard Eden for his alchemical abilities.

In late 1549 Whalley, having heard of Eden's skill with metals, approached him for assistance with running the mines in Nottinghamshire. That Eden had already established a significant metallurgical reputation so soon after leaving university, suggests that he developed this knowledge while at Cambridge. Eden replied to Whalley that his particular experience lay not in mining but in seeking "workes of greater subtilite ... the philosopher's stone, Aurum potabile, and Quinta Essentia". ${ }^{131}$ This obviously piqued Whalley's interest as he again sought out Eden, who

shewed hym a boke which I hade then abowte me, towchinge thes matters, wrytten with myne owne hande \& gathered owte of sundrye auctours, declaringe forther to hym that, at the request of Syr John Yorke I entended to present that boke to my Lorde of Warwike, nowe Duke of Northumberlande. ${ }^{132}$

Both Eden and Sir John York, assay master at the mint at the Tower of London, and financial backer of the coup against Somerset, believed that Warwick, now Duke of Northumberland, would appreciate a collection of alchemical works. Amongst the highest ranks of society, alchemical ideas had a legitimacy that would endure throughout the Tudor period.

In an even stronger demonstration of this confidence in alchemy, Whalley proceeded to offer Eden a position as his personal alchemist, telling Eden that he "had a

\footnotetext{
128 Ibid.

${ }^{129}$ Ibid.

130 Ibid.

${ }^{131}$ Richard Eden, undated, TNA, SP 46/2 ff. 164-7 reproduced in Kitching, "Alchemy in the Reign of Edward VI', p. 311.

132 Ibid. p. 312.
} 
great pleasure in the workes of Nature \& Arte [a common euphemism for alchemy]". ${ }^{133}$ Elizabeth Spiller argues that Whalley may have hoped to use alchemy to finance Somerset's restoration. ${ }^{134}$ If so, it is remarkable that Whalley, a close associate of Cecil, would pin his political hopes to Eden's alchemical success. Inevitably however, within two years the pair had fallen out over the lack of progress. As alchemically multiplying metals without a licence was illegal, Eden confessed their activities to the authorities. ${ }^{135}$ Whilst Whalley was imprisoned, the Privy Council, including Cecil, let Eden off with a promise to refrain from unlicensed transmutation in the future. ${ }^{136}$ The episode reveals an interest in philosophical and practical alchemy at the Edwardian Court not appreciated by previous historians.

Surviving the failure of his alchemical schemes, Eden sought to strengthen his ties to the newly knighted Sir William Cecil, becoming his private secretary in $1552 .{ }^{137}$ Most have attributed Eden's appointment as an attempt to publicise the Earl of Northumberland's planned voyages to America and the Far East. While the publication of Eden's translation $A$ Treatyse of the Newve India in 1553 suggests that Cecil valued Eden as a publicist for the developing imperial agenda of the period, Eden's intellectual and alchemical interests would have also appealed to the privy counsellor. ${ }^{138}$ He certainly knew of Eden's experiments for Whalley. Eden probably ended his employment as private secretary sometime after 1554, as "in the time of Queen Mary, he was again placed in the treasury of King Phillip, through the favour of certain Spanish nobles". ${ }^{139}$ His fawning admiration for the Spanish empire in his translation of The Decades of the Newe World or West India (1555) likely reflects this favour. However, coming under suspicion of heresy near the end of 1555, Eden was forced to surrender his office. ${ }^{140}$

\footnotetext{
133 Ibid.

${ }^{134}$ Elizabeth Spiller, Science, Reading, and Renaissance Literature: the Art of Making Knowledge, 1580-1670, Cambridge, 2004, p.187n.

135 Kitching, "Alchemy in the Reign of Edward VI', p. 309.

${ }^{136}$ John Roche Dasent (ed.), APC, Volume IV: A.D. 1552-1554, London, 1892, p. 279.

137 Hadfield, 'Eden, Richard'.

138 Richard Eden, Treatise on the Newe World or West India, London, 1555.

${ }^{139}$ Eden, in Arber, The First Three English Books on America, p. 408.

140 Ibid.
} 
Whilst there is little record of Eden over the next few years, his next correspondence with Cecil warrants special attention. Eden wrote to Cecil in August 1562, appealing to him specifically as a patron of alchemical learning. ${ }^{141}$ Firstly Eden thanked Cecil for his recent "favour \& goodnesse towarde me in your lately ernest travaile in my behalfe". ${ }^{142}$ As convention required, Eden compared Cecil to the famous Roman patron of the arts Gaius Maecenas, grateful that due to the "vertues as it hathe pleased you to thinke comendable in me ... I maye hereafter with quietnesse spende my tyme in studie". ${ }^{143}$ It seems that the Master of Savoy Hospital, Thomas Thurland, had conveyed this message of favour from Cecil, along with $£ 20$ to fund the translation of Pliny's Naturalis Historia, which deals extensively with Eden's most favoured subjects: cosmography and metallurgy. ${ }^{144}$ Eden was sure of the value of the work as "it is not unknown unto your L[ordship] that the Latins receaving bothe the science of philosophie and phisike of the Greeke". ${ }^{145}$ While there is no evidence Eden completed the translation, he insisted it could be done, despite Cecil's concerns that "the booke coulde not be translated into the Englisshe toonge". ${ }^{146}$ Even if Cecil was sceptical of the practicalities of the translation, this was clearly a matter that interested him and on which they had corresponded before.

Knowing Cecil "to take pleasure in the wonderfull woorkes of arte and nature", Eden sent with his letter a "philosophicall booke, wherin is described ... so excellent and precious an experiment, wrought by arte to the similitude of the universall frame of the worlde". ${ }^{147}$ The book described an alchemical experiment, which replicated the universe in microcosm, and when compared to the automatons of the alchemist Roger Bacon "this Michrocosmos so far suremount it, as nature passeth arte". ${ }^{148}$ For Eden the experiment

\footnotetext{
141 Richard Eden to Cecil, 1 August 1562, BL, Lansdowne, Vol. 101. No 5.

142 Ibid.

143 Ibid.

144 Ibid.; Gian Biangio Conte, Joseph B. Solodow, Don P Fowler and Glenn W. Most, Latin Literature: A History, Baltimore, 1999, p. 498.

145 Eden to Cecil, Lansdowne, Vol. 101. No 5.

146 Ibid.

147 Ibid.

148 Ibid.
} 
demonstrated the divine spirit of life that moved all nature, which "seemeth to agre with that Cornelius Agrippa hathe written in his second booke De occulta philosopia". ${ }^{149}$

Eden then claimed to have completed a similar work himself when patronised by Richard Whalley. He gave Cecil a full account of his alchemical experiment, in which he created, through transmutation, "a hundreth sylver trees about an ynche high, so perfectly formed with trunkes, stalkes and leaves". ${ }^{150}$ The seventeenth century alchemist Eirenaeus Philalethes in, Secrets Reveal'd: or, an Open Entrance to the Shut-Palace of the King (1669) also described an experiment that created "tiny silver trees, with twigs and leaves". ${ }^{151}$ Rather than a "wishful fantasy of territorial acquisition", they were in fact observing a legitimate chemical process. Nineteenth century chemists such as Johann Wilhelm Ritter experimented with what they called "Diana's silver tree". ${ }^{152}$ The precipitation of nitrate of silver by means of mercury created "the form of a tree, producing a very beautiful appearance". ${ }^{153}$ To alchemists the growth of the tree was "evidence of a vital spirit or 'seed of gold' at work ... the tree was a step in the process for making the Philosophers' Stone". ${ }^{154}$ It was Cecil's education that made Eden sure that he would be fascinated by the experiment, especially because Cecil had received the "divine spark of knowledge" from John Cheke. ${ }^{155}$ Eden was sure that anyone educated in the same intellectual traditions as himself would agree that "there is nothing so delectable as to beholde the infinite powre and wysdome of god in his creatures". ${ }^{156}$

Throughout Eden's 1562 letter he referred to a number of authors in a manner suggesting Cecil's familiarity with their works. Some of these, such as Aristotle, Philo,

\footnotetext{
149 Ibid.

150 Ibid.

${ }^{151}$ Eirenaeus Philalethes, Secrets Reveal'd: or, an Open Entrance to the Shut-Palace of the King, London, 1669, p. 28.

152 Roberto De Andrade Martins, 'Orsted, Ritter, and Magnetochemisty', in Robert Michael Brain, Robert

Sonne Cohen, Ole Knudsen(eds.), Hans Christian Ørsted and the Romantic Legacy in Science: Ideas, Disciplines, Practices, Dordrecht, 2007, pp. 347-349.

${ }^{153}$ John Comstock, A Grammar of Chemistry, Cambridge, Mass., 1825, p. 93.

${ }^{154}$ John C. Powers, “Ars Sine Arte:' Nicholas Lemery and the End of Alchemy in Eighteenth-Century France' in Allen G. Debus (ed.), Alchemy and Early Modern Chemistry: Papers from Ambix, Huddersfield, 2004, pp. 525-526.

${ }^{155}$ Eden to Cecil, Lansdowne, Vol. 101. No 5.

156 Ibid.
} 
Marcus Manilius and Plato, had formed the core of Cecil's classical education. ${ }^{157}$ However, he also referred familiarly to Georgius Agricola, author of the metallurgical work $D e$ Re Metallica; the famous medieval English alchemist Roger Bacon; and the humanist occultist Cornelius Agrippa. ${ }^{158}$ Eden clearly believed that, even if Cecil had not read their work, he was familiar with their ideas. Eden, like Thomas Smith and many of those who would appeal to Cecil as a patron of alchemy, certainly subscribed to Agrippa's particular blend of restored medieval magic and Christian Cabala. It is likely that this work was part of the informal study that influenced many Cambridge educated scholars.

Eden's failure to complete his translation of Naturalis Historia had less to do with a lack of further support from Cecil, than him entering the service of Jean De Ferrieres, the Vidame (principal lay officer) of the bishopric of Chartres. ${ }^{159}$ As an influential member of the Huguenot party in France, the Vidame came to England in 1562 seeking English support. While negotiating the Treaty of Hampton Court, in which Elizabeth committed money and men to the French Protestant cause, the Vidame's philosophical interests brought him in contact with Eden. ${ }^{160}$ The combination of their common interest in alchemy and Eden's impressive linguistic skills would have made Eden an ideal secretary for the Vidame.

Eden's activities during his time serving the Vidame are largely unknown. He would later state that he lived with the Vidame "for ten years and more in Germany and France, with varying fortune" and that it was "only in consequence of changeful and adverse fortune; that he was not enriched". ${ }^{161}$ When the Vidame wrote to Cecil in early 1565 to commend Richard Eden to him, he wrote that his "labours are more about celestial than terrestrial matters", suggesting that Eden was employed more for his astrological and

\footnotetext{
157 Riehl Leader, A History of the University of Cambridge, Volume 1, p. 349.

${ }^{158}$ Eden to Cecil, Lansdowne, Vol. 101. No 5.

${ }^{159}$ Joycelyne Russell, Peacemaking in the Renaissance, Philadelphia, 1986, p. 278.

${ }^{160}$ Hadfield, 'Richard Eden'.

161 Richard Eden to Queen Elizabeth, 1572, Reprinted and trans. in Arber (ed.), The First Three English Books, pp. xlv-xlvi.
} 
alchemical knowledge than his geographical expertise. ${ }^{162}$ During his travels Eden would certainly have associated with the other prominent alchemists whom the Vidame patronised. Jaques Gohory, author of several Paracelsian and alchemical tracts, including an edition of the medieval alchemical poem Livre De La Fontaine Perilleuse (1572), dedicated to the Vidame, shared common interests with Eden. ${ }^{163}$ As well as advocating Paracelsian medicine as the heir to the alchemical tradition of Roger Bacon, Gohory was fascinated with the New World, writing the first treatise on tobacco and translating an Italian account of the conquest of Peru. ${ }^{164}$ The association of alchemy with other forms of natural knowledge was not uncommon in sixteenth century Europe.

During his employment by the Vidame, Eden kept in contact with both Cecil and Thomas Smith. Their correspondence was almost entirely related to Eden's alchemical interests and experiments. In October 1565 Eden wrote to Cecil to tell him "that of late there passed by us frome the [presumably French] courte a Spaniard, a gentelman, and learned, named Don Francisco Tiburino". ${ }^{165}$ The Spaniard told him that he had seen one of the King's physicians reading a occult book, written by an Englishman, although he could not name the title or author. The text which the Spaniard had quoted to Eden "sound to me so strange that I coulde imagen none other but that it shuld be the booke of Roger Bacon" though Eden remained uncertain about the author, so he thought he would inform Cecil, "who I suppose maye sooner knowe the truth of this thing than I". ${ }^{166}$ That Eden, who by this stage had known Cecil for over twenty five years, thought that Cecil would take the time from his many duties to hunt down a book of occult philosophy further reveals Cecil's contemporary reputation.

\footnotetext{
162 Vidame de Chartres to Sir William Cecil, 3/3/1565, in Joseph Stevenson (ed.), CSPF 1564-5, London, 1870 , p. 310 .

163 Denis I. Duveen, Bibliotheca alchemica et chemica: An Annotated Catalogue of Printed Books On Alchemy, Chemistry and Cognate Subjects In The Library of Denis I. Duveen, London, 1965, p. 262.

164 Astor Lenox, Bulletin of the New York Public Library, Vol. 3, New York, 1899, p. 18.

165 Richard Eden to William Cecil, 12 October 1565, TNA, SP 70/80/123.

${ }^{166} \mathrm{Ibid}$. Although Eden attributes the authorship of the book to Roger Bacon, based on his description of its content it seems possible that it may have been a copy of John Dee's Monas Hieroglyphica published the previous year.
} 
After the 1572 St. Bartholomew's Day massacre of French Protestants, from which the Vidame and Eden barely escaped, Eden returned to England. In 1573 the Vidame petitioned the Queen, to admit her former servant as a Poor Knight of Windsor, an order set up to maintain impoverished military veterans. ${ }^{167}$ An attached autobiography was evidently intended to support this application, asserting that Eden had made much progress in unlocking the secrets of nature. ${ }^{168}$ Assuming the Queen's interest in alchemy, Eden complained that one could not "compound the admirable medicaments of Paracelsus from metals and minerals ... without immediately incurring from ignorant calumniators the infamy and peril of practising alchemy". ${ }^{169}$ Therefore he also requested a royal licence exempting him from the ban on the multiplication of metals, since in England many "foreigners freely practise [alchemy]; that the same will, with more justice, be granted to me by the royal authority". ${ }^{170}$ Elizabeth never granted any such authority, and Eden died shortly after, in 1576. Late in his life Eden continued to maintain an interest in alchemy and believed his alchemical knowledge to be of as much value as his translation of the "several books useful to the State" that have formed his posthumous reputation. ${ }^{171}$

Eden's historical importance has always been tied to his role as propagandist for a new British empire, rather than his alchemical interests. However, the various pursuits of his private, intellectual career reflected the mentality of Elizabethan intellectuals. Eden's letters, if not his published works, show an ongoing fascination with both the practical challenge and philosophical implications of alchemy. Not only was a serious interest in the occult sciences compatible with the imperial outlook so often assigned to Elizabethans, for men like Eden it embodied the humanist attempt at recovering a unified understanding of nature. Eden believed Cecil, whom he had known for decades, shared this fascination. His

\footnotetext{
167 Arber (ed.), The First Three English Books on America, pp xlv.

168 Ibid., pp. xlv-xlvi.

169 Ibid., pp xlvi.

170 Ibid.

171 Ibid.
} 
reports to Cecil are almost exclusively on alchemically related matters, and Eden remained assured of Cecil's interest in both practical and philosophical alchemical endeavours.

During Cecil's time in Protector Somerset's service he worked closely with the Duke's steward, Sir John Thynne (1512-1580). Although Thynne largely retired from court life under Elizabeth, he remained on friendly terms with Cecil. It is likely this connection that introduced Cecil to John's younger cousin, Francis Thynne. The son of William Thynne, the first scholarly editor of Geoffrey Chaucer and member of Henry VIII's household, Francis Thynne was one of the most important writers on the occult, history, and heraldry in the Elizabethan period. While he did not attend university, he obtained a classical education during his time at Lincoln's Inn, one of London's Inns of Court. ${ }^{172}$ Despite his extensive family and patronage connections, Thynne lived much of his life in relative poverty, reliant on his cousin's wealth and Cecil's patronage.

David Carlson has convincingly argued that the particular combination of interests held by Francis Thynne make him

a particularly important figure for explaining the intellectual behavior of the Elizabethan period's learned elite. The peculiar make-up of intellectual life during and briefly after the reign of Elizabeth is encapsulated microcosmically, to use a favorite sixteenth century notion, in Thynne's career. $^{173}$

For a quarter of a century, Cecil, who shared this "broader comprehension" of the universe, was the target of Thynne's poverty induced appeals for patronage. Historians have largely ignored this connection, assuming that it was only Thynne's expertise in heraldry that appealed to Cecil. In fact Cecil's patronage of Thynne was based on an interest in not only heraldry and history, but also alchemical philosophy and astrology.

\footnotetext{
172 Louis A. Knafla, 'Thynne, Francis (1545?-1608)', Oxford Dictionary of National Biography, Oxford, 2004 [http://www.oxforddnb.com/view/article/27420].

${ }^{173}$ David Carlson, 'The Writings and Manuscript Collections of the Elizabethan Alchemist, Antiquary, and Herald Francis Thynne', The Huntington Library Quarterly, Vol. 52, No. 2, 1989, p. 220.
} 
Thynne's poem A Discourse uppon the Lord Burghleyghe his creste, written to Cecil in August 1573, contains some of the most obvious attempts to appeal to Cecil using alchemical analogies. Combining Thynne's two great passions, the occult and heraldry, it describes a vision in a dream, in which "the Dragon with quick-silverd face, approchd my sight with wise \& pleasant grace" and directed Thynne to seek the man "as worthiest in this land, under that one whiche secret wonder bredes". ${ }^{174}$ The mercurial dragon described the man using a series of astrological metaphors

He is the lowest, and stalld in myddle place, and by the course of heaven rules next the beste;

sett next the higheste, whose flaminge shyninge face, In Ceres shape dothe by Diana reste, And azurd skye supported to his prayse, whose lyvinge fame shall blome in following dayes. ${ }^{175}$

Initially Thynne interpreted these astrological metaphors for the Moon, Sun and Jupiter as referring to their corresponding metals; silver, gold and tin. Thynne's mind therefore turned to the "true and secret skill Voarchoadumye [Voarchadumia]". ${ }^{176}$

In his book Voarchadumia contra alcbimiam: ars distincta ab archimia et sophia (1530), Johannes Augustinus Pantheus, a Venitian priest, devised Voarchadumia as a cabalistic transmutational art, in order to circumvent Venetian and Papal laws against alchemy. ${ }^{177}$ Described by Lynn Thorndike as "a sort of cabala of metals", Voarchadumia drew upon the occult philosophy of Ramon Lull, just as Lull had co-opted the Jewish mystical tradition of Cabala, using letter notations corresponding to the different names or attributes of God in order to prove the truth of the Christian trinity. ${ }^{178}$ Thynne expected Cecil to both know of, and understand, Voarchadumia and thus positioned his alchemical knowledge as part of the more general pursuit of religious and natural truth.

\footnotetext{
${ }^{174}$ Francis Thynne, 'A Discourse uppon the Lord Burghleyghe his creste', 2 August 1573, reproduced in F. J. Furnival (ed.), Animaduersions uppon the Annotacions and Corresctions of Some Imperfections of Impressiones of Chaucers Workes (sett downe before tyme, and nowe) reprinted in the yere of oure lorde 1598, London, 1865, p. 104. 
Thynne also affirmed the importance of religious faith for the effective employment of his alchemical knowledge. Alchemy must be "perfectly usd by grace of hevenly sprite, (for with-oute that, tis subtill vanytie, and mere deceyte unfytte for skilles wighte)" ${ }^{179}$ In describing "what secret mystrye heavenly planetts holde" Thynne carefully displayed his alchemical and astrological knowledge. ${ }^{180}$ He explained to Cecil that the dream could not refer to alchemy, as Saturn, the symbol for the essential alchemical lead was not present. Thynne, after a series of twisting astrological analogies described his discovery that the metaphors referred to the Cecil's crest,

Not olde foreworne Cecilius, britaine kinge, almost consum'd by gnawing tyme \& space; but he whiche did from Auncient Sicill springe, Lord Burgley, Cecill, borne of gentle race, whome princely garter, whith his azurd hue dothe bewtyfye with mede for honor due ${ }^{181}$

In mentioning Cecil's supposed descent from the legendary British king Sisillius, Thynne sought to appeal to his pretentions of noble lineage.

By March 1576 Thynne had been imprisoned for debt. He wrote Cecil two letters, pleading for assistance. The first is similar to many requests Cecil received from prisoners, offering vague services in return for their release. Thynne only stated that while previously bad fortune had not allowed him to

make manifest unto you either the perfect knowledge of my persone, or the dowryes of my mynde ... alwayes in secret [I] hathe wished reasone to disclose what lyeth burried therin towardes your honor in any service I ame able to performe. ${ }^{182}$

Deceived by his relatives, Thynne looked to Cecil-praising his justice, courtesy and learning — to free him from an increasingly hopeless situation.

Thynne's second letter of 19 March 1576 appears considerably more desperate. Filled with astrological, alchemical and heraldic analogies, it is easy to understand how the

\footnotetext{
179 Thynne, 'A Discourse uppon the Lord Burghleyghe', p. 109.

180 Ibid.

${ }^{181}$ Ibid., p. 114.

${ }^{182}$ Francis Thynne to Cecil, 13 March 1576, BL, Lansdowne, Vol. 21, No. 57.
} 
eighteenth century cataloguer of the Lansdowne manuscripts judged Thynne a madman. ${ }^{183}$ However, through his astrological interpretation of Cecil's crest as "the golden sheife, supported with the two honorable lyons of jupiter \& luna, therein representinge unto mee ye majesty of ye golden phebus [sun]", Thynne referenced his earlier astrological and alchemical discourse, and thereby revealed the occult nature of his potential service. ${ }^{184}$

While we cannot definitively identify the nature of Thynne's proposed occult services, there are indications that Thynne was referring to the alchemical 'Voarchadumia' in which he had previously professed his skill. Thynne promised that in return for his freedom, Cecil could "bee partaker of that simple treatice which I have longe tyme since dedicated unto your honor", which he could no longer undertake, as "my foortune may not beare it". ${ }^{185}$ This is significant as Frederick Fernivall has postulated that Thynne's growing interest in alchemy in the 1570 's contributed to his poverty. ${ }^{186}$ Thynne claimed to be "famuliar in practice" with alchemy and the pursuit commonly impoverished those with chemical aspirations. ${ }^{187}$

Evidently Thynne's alchemical allusions intrigued Cecil enough to procure his release within three months. ${ }^{188}$ Thynne, along with "the Reliques of my spoyled Librarie", moved into his cousin's Longleat House. ${ }^{189}$ Although Thynne’s debt had forced him to sell off a significant proportion of his books, he retained a sizeable library, some of which still remains at Longleat House. These almost exclusively consist of alchemical and astrological works including Ripley's Compendium of Alchemy, Thomas Norton's Ordinal of Alchemy, and Joanne de Anglia's obscure Stella Alchymiae. ${ }^{190}$

\footnotetext{
${ }^{183}$ H. Ellis and F. Douce (eds.), A Catalogue of the Lansdowne Manuscripts in the British Museum: With Indexes of Persons, Places and Matters, London, 1819, p. 43.

184 Thynne to Cecil, 19 March 1576, BL Lansdowne, Vol. 21, No. 58.

185 Ibid.

${ }^{186}$ Furnival (ed.), Animaduersions, p. cxiv.

${ }^{187}$ Francis Thynne, 'A Treatise on the Philosopher's Stone' (copy dated 9 September 1573), reproduced in Fernivall, Animadversions, p. cxiv .

${ }^{188}$ Francis Thynne wrote to his cousin Sir John Thynne "From my cousin Becher's" 6 June 1576, quoted in Fernivall, pp. lvii-lviii.

${ }^{189}$ Francis Thynne to Lord Cobham, 8 January 1579, reproduced in Fernivall, Animadversions, p. lxi.

${ }^{190}$ Historical Manuscripts Commission, Third Report of the Royal Commission on Historical Manucripts, Appendix, London, 1872, p. 186.
} 
From Longleat Thynne wrote for Cecil a manuscript copy of 'Homo Animal Sociale', which he submitted in October 1578. Intended to "desplay my inwarde mynde who alwayes dothe \& shall acknowegde your undeserved curtesye", the work was clearly intended as thanks for Thynne's release from prison. ${ }^{191}$ 'Homo Animal Sociale', written in English and Latin, presented to Cecil Thynne's cabalistic view of the universe, examining the "Hierogliphics or letters of mysticall meaninge only knowen to their wise philosophers \& priestes". ${ }^{192}$ Thynne revealed that he had become engrossed in the mystical symbolism of the ancient alphabets after "the lerned Cabaliste Mr Dee observinge in his booke entituled Monas Hieroglyphica ... hiddenly left unto us a most profounde knowledge". ${ }^{193}$ Both Dee and Thynne, believed that by examining the physical shapes of the ancient alphabets they could retrieve the original magical and alchemical knowledge of the biblical patriarchs. ${ }^{194}$ Cecil too would undoubtedly have been familiar with the Monas Hieroglyphica from his correspondence with Dee while it was being written.

By 1579 Thynne had shifted his attention toward another characteristically Elizabethan interest: British antiquities. Perhaps his obsession with alchemy had proved too costly for the perpetually indebted scholar. David Carlson suggests that there were "substantive similarities between alchemy and antiquarianism as kinds of intellectual work that would have made the two complementary pursuits for Thynne". ${ }^{195}$ They had both practical and theoretical foundations in common, as "both were fundamentally acquisitive, proceeding by amassing and interpreting a wealth of rare details" and required an arcane understanding only available to the initiated. ${ }^{196}$ As one of the writers of Raphael Holinshed's massive Chronicles of England, Scotland and Ireland (1587) and as a member of the Elizabethan Society of Antiquaries, Thynne maintained both a strong scholarly reputation

\footnotetext{
${ }^{191}$ Francis Thynne to Cecil, 'Homo Animal Sociale', 1578, BL, Lansdowne Vol. 27 No. 36.

192 Ibid.

193 Ibid.

194 Ibid.

195 Carlson, 'The Writings and Manuscript Collections', p. 215.

196 Ibid., p. 216.
} 
and the patronage of Cecil. His appointment as Lancaster Herald in 1602, nearly four years after Cecil's death, reflected the prevalence of Thynne's broad range of interests in Elizabethan society. ${ }^{197}$

Cecil's interest in alchemical philosophy demonstrates that not only did he believe in the feasibility of alchemical transmutation, but that this belief was an essential consequence of his understanding of the world. Alchemical theory, as it existed in the sixteenth century, was a conglomeration of various spiritual, magical, and metallurgical ideas. Whilst these concepts were often paradoxical, they had at their core a unified understanding of nature, based on the elemental theory of Aristotle. The unity of nature, as implied by the unity of creation, allowed for both the occult effects of the heavens and the alchemical transmutation of metals. Cecil's education, steeped in Aristotelian philosophy, therefore encouraged a worldview complementary alchemy. Further, the interests of Cecil's tutors John Cheke and Thomas Smith suggest that explicitly alchemical and occult works were amongst those read unofficially, through private study.

Whilst John Dee's actions during Queen Mary's reign tainted his relationship with Cecil, their common education informed Dee's decision to appeal to Cecil using occult knowledge. Dee did not copy Steganographia for Cecil for its cryptographic secrets: these were not known at the time. Rather, Dee copied it because he thought Cecil would be interested in a rare and authoritative source of occult and alchemical knowledge. Richard Eden—after attending Cambridge with Cecil and acting as his secretary-appealed Cecil's intellectual curiosity and "pleasure in the wonderfull woorke of arte and nature" ${ }^{198} \mathrm{He}$ knew that Cecil was fascinated by not only the practical applications of alchemy, but also in its philosophical implications. Francis Thynne's demonstrations of his knowledge of occult knowledge successfully played upon this fascination, gaining Cecil's patronage and relieving

\footnotetext{
${ }^{197}$ Knafla, 'Thynne, Francis'.

${ }^{198}$ Eden to Cecil, Lansdowne, Vol. 101, No. 5.
} 
his desperate financial situation. These men, like Cecil, held a worldview that complemented alchemical theory. This chemical understanding of nature also had implications for sixteenth century medical practice. Chapter two therefore examines Cecil's patronage of various forms of alchemical medicine. 


\section{Chapter 2: Alchemical Medicine}

Cecil's patronage of chemical medicine provides one of the best examples of his belief in alchemical principles. Increasingly in the second half of the sixteenth century medicines based on an alchemical understanding of the human body began to challenge established medical techniques. In order to examine Cecil's interest in these new chemical medicines this chapter first considers the background of medical practice in the Elizabethan period. It then analyses a number of case studies, both of Cecil's medical patronage, and attempts by practitioners to attract Cecil's benefaction through promises of effective alchemical medicines.

While recent scholarship has helped place chemical medicine within the context of sixteenth century medical practice, studies on medical patronage in the period are conspicuous in their scarcity. Those studies which do exist tend to focus on continental European examples, such as Didier Kahn's study of King Henry IV of France's patronage of Paracelsian physicians. ${ }^{1}$ One of the few English examples, Elizabeth Furdell's The Royal Doctors 1485-1714 (2001) reveals the complex relationship between the royal patronage of chemical, or 'irregular', practitioners, and the royally sanctioned London College of Physicians. $^{2}$ The patronage role of leading nobles and politicians, however, has been largely overlooked.

Perhaps the primary reason that historians have ignored Cecil's patronage of chemical medicine is the lack of easily accessible sources. Whilst there is some evidence of Cecil's consultation with orthodox physicians, his interactions with unlicensed practitioners left far fewer traces. With few exceptions, even successful irregular medical physicians left

\footnotetext{
${ }^{1}$ Didier Kahn, 'King Henry IV, Alchemy, and Paracelsianism in France (1589-1610), in Lawrence M. Principe (ed.), Chymists and Chymistry: Studies in the History of Alchemy and Early Modern Chemistry, Sagamore Beach, 2007, pp. 1-12.

${ }_{2}^{2}$ Elizabeth Furdell, The Royal Doctors, 1485-1714, Rochester, 2001.
} 
no significant records of their practices. ${ }^{3}$ However, by examining the limited number of case studies about which records survive, we can gain some insight into Cecil's patronage of alchemical medicine.

Alchemical philosophy and methods provided some key elements of Renaissance medical practice. The fifteenth century humanist rediscovery of the Roman pagan physician Galen's medical texts, which centred on the concept of rectifying imbalanced humours, created the dominant medical philosophy of the Renaissance. ${ }^{4}$ While the rise of humanism supported the re-emergence of Galenic medicine, it also revived alchemical medicine as a separate and sometimes competing system of knowledge. Some physicians believed that alchemy had a more ancient, Judeo-Christian ancestry than medical concepts derived from the ancient pagan world. ${ }^{5}$

The use of alchemical medicines had a long tradition in England. In the thirteenth century Roger Bacon sanctioned the quest to cure diseases using alchemy that, short of finding the mythical philosopher's stone, entailed the creation of chemical medicines. ${ }^{6}$ Alchemy justified the distilling of medicines based on metallic and alcoholic compounds, later known as iatrochemistry. Whilst traditional alchemy and iatrochemical medicine most obviously shared common techniques and practices, alchemical symbolism, especially the macrocosm/microcosm analogy, had considerable implications for medical practice. ${ }^{7}$ Charles Webster convincingly argues that to understand alchemy's medical application one must consider not only its practical relevance, but also that its aim

to create a total and harmonious relationship between man and the universe...[was] important in securing the serious commitment of the

\footnotetext{
${ }^{3}$ The significant exception was the notorious astrologer and medical practitioner Simon Forman, who left many volumes of papers. There is, however, no evidence of Cecil ever consulting with Forman. See Lauren Kassell, Medicine and Magic in Elizabethan London: Simon Forman: Astrologer, Alchemist, \& Physician, Oxford, 2005. ${ }^{4}$ Margaret Pelling and Charles Webster, 'Medical Practitioners' in Charles Webster (ed.), Health, Medicine and Mortality in the Sixteenth Century, Cambridge, 1979, p. 165.

${ }^{5}$ Charles Webster, 'Alchemical and Paracelsian Medicine' in Webster (ed.), Health, Medicine, p. 316.

${ }^{6}$ Ibid., p. 302.

7 Webster, 'Alchemical and Paracelsian Medicine', p. 314.
} 
practitioner and in introducing a convincing ritual context for the treatment of disease. ${ }^{8}$

As the medical philosophy of the German physician Phillip von Hohenheimknown as Paracelsus - spread throughout Europe in the later sixteenth century, alchemical medicine evolved into a coherent alternative to the Galenic tradition. Paracelsus taught a consistent medical philosophy that justified the use of alchemical medicines. Unlike the Galenists, who saw disease as an imbalance of the humours, Paracelsus conceived illness as a localised problem in one of the body's alchemical processes.' According to Paracelsus these problems caused imbalances in the body's three elements: the alchemical tria prima of salt, sulphur, and mercury. ${ }^{10}$ Paracelsian physicians saw the body as a microcosm of the wider world. Just as metals grew and matured in the earth through an alchemical union, so a human organ "acted as an alchemist separating pure from impure"." Just as the alchemist used his art to hasten the earth's natural process, so physicians could heal diseased organs with metallic and mineral compounds, often containing poisonous levels of mercury, arsenic, or lead. ${ }^{12}$

Paracelsus connected his philosophy with the reformist religions of Germany, in opposition to Galen's Roman paganism. ${ }^{13}$ While this helped to spread Paracelsian medicine throughout the Protestant regions of northern Europe, there is a degree of historical debate as to its importance in sixteenth century England. Studies of vernacular medical literature have tended to argue that until the Interregnum period Paracelsianism was less influential in England than the rest of Europe. ${ }^{14}$ More recent approaches, focussing on the presence of Paracelsian texts in the libraries of prominent philosophers

\footnotetext{
8 Ibid. p. 314-15.

${ }_{9}^{9}$ Charles Webster, Paracelsus: Medicine, Magic and Mission at the End of Time, New Haven, 2008, pp. 134-36.

10 Ibid.

${ }^{11}$ Alan Debus, Chemistry and Medical Debate: Van Helmont to Boerhaave, Canton, 2001, p. 13.

12 Webster, Paracelsus, pp. 138-40.

13 Webster, 'Alchemical and Paracelsian Medicine', p. 316.

${ }^{14}$ P. H. Kocher, 'Paracelsian Medicine in England: The First Thirty Years (ca. 1570-1600)', Journal of the History of Medicine, Vol. 11, 1947, pp. 451-80.
} 
such as John Dee and country gentlemen such as Sir Thomas Kyvett, have argued for an earlier and more pervasive dissemination of Paracelsian ideas. ${ }^{15}$ Alan Debus argued that from 1558 returning Marian exiles introduced Paracelsian concepts into England, while Charles Webster contended that by 1600 Paracelsus' ideas had been widely disseminated throughout English medical practice. ${ }^{16}$

Due to the paucity of provincial sources, studies of the sixteenth century medical profession have focused on London. Since 1518 the London College of Physicians had monopolised the licensing of medical practitioners, and punished what it considered unqualified and unlicensed practitioners. ${ }^{17}$ The College assessed medical knowledge according to a strict Galenic model, and officially rejected the use of chemical treatments. ${ }^{18}$ However, due to the limited availability of licensed physicians (there were less than fifty throughout the Elizabethan period), a number of other groups competed for the right to practice medicine. ${ }^{19}$ Members of the Company of Barber-Surgeons, while theoretically limited to performing surgical procedures, often also engaged in general medical practice. ${ }^{20}$ Although the Barber-Surgeons adopted Galenic principles in order to appease the College of Physicians, they accepted Paracelsian ideas much earlier. ${ }^{21}$ Apothecaries, a major force in the larger Company of Grocers, sold medicines ranging from herbal remedies, including tobacco, to Paracelsian chemical treatments. ${ }^{22}$ The College of Physicians prosecuted members of both the Barber-Surgeons and the Apothecaries for the illegal practice of medicine throughout the Elizabethan period. ${ }^{23}$

\footnotetext{
15 Webster, 'Alchemical and Paracelsian Medicine', p. 321. Clulee, John Dee's Natural Philosophy, p. 13.

${ }^{16}$ Alan G. Debus, The Chemical Promise: Experiment and Mysticism in the Chemical Philosophy, 1550-1800, Sagamore Beach, 2006, p. 77; Webster, 'Alchemical and Paracelsian Medicine', p. 323.

17 Margaret Pelling, Medical Conflicts in Early Modern London: Patronage, Physicians, and Irregular Pracitioners, 1550 1600, Oxford, 2003, p. 1.

18 Ibid., p. 17.

${ }^{19}$ Pelling and Webster, 'Medical Practitioners', p. 169.

${ }^{20}$ Ibid., pp. 173-75.

${ }^{21}$ Webster, 'Alchemical and Paracelsian Medicine', p. 327.

22 Pelling and Webster, 'Medical Practitioners', pp. 177-78.

${ }^{23}$ See Margaret Pelling and Francis White (eds.), Physicians and Irregular Medical Practitioners in London 1550-1640:

Database, 2004, [http://www.british-history.ac.uk/report.aspx?compid=17251].
} 
Alongside these official groupings, there existed a large number of unlicensed medical practitioners. Charles Webster and Margaret Pelling estimate that towards the end of the sixteenth century there were approximately 250 irregular practitioners in London, similar to the total number of physicians, surgeons, and apothecaries in the city. ${ }^{24}$ Once written off by historians as quacks or empirics, more recent studies have revealed the importance and diversity of these medical outsiders. ${ }^{25}$ Despite the best efforts of both the College of Physicians and the Company of Barber-Surgeons, these practitioners probably remained the source of most medical treatment in London. ${ }^{26}$ While many were uneducated, a few had qualifications matching those of members of the College of Physicians. ${ }^{27}$ Often these men and women were immigrants, helping to disperse the new medical ideas that were spreading throughout Europe. These unlicensed practitioners were therefore the first to utilise Paracelsian treatments. ${ }^{28}$

Cecil, like most courtiers, took an active interest in the medical developments of the period. Never in vigorous health, from his early thirties Cecil suffered terribly from gout. ${ }^{29}$ As his wealth and prominence increased, Cecil was bombarded with offers of cures and treatments for his gout from a variety of medical practitioners. A high proportion of these remedies involved the use of alchemical and Paracelsian medicines. While many offers were unsolicited, they do suggest that Cecil had gained a reputation for being sympathetic to alchemical ideas. On other occasions not only did Cecil accept offers of chemical medical assistance, he even appears to have actively sought out and defended alchemical medical practitioners.

\footnotetext{
24 Pelling and Webster, 'Medical Practitioners', p. 183.

25 Pelling, Medical Conflicts

${ }^{26}$ Pelling and Webster, 'Medical Practitioners', p. 183-85.

27 Ibid.

${ }^{28}$ Ibid., p. 9.

${ }^{29}$ W. S.C. Copeman, 'The Gout of William Cecil-First Lord Burghley (1520-98)', Medical History, Vol. 1, 1957, p. 262.
} 
The late 1560s saw the first significant introduction of Paracelsian philosophy into the medical marketplace. The College of Physicians and Company of Barber-Surgeons increasingly accused unlicensed practitioners of administering chemical medicines. ${ }^{30}$ Even the prominent London physician William Bullein's Bulwarke of Defence Againste All Sicknes (1562) — a largely Galenist text which characterised alchemical practitioners as being small minded and reliant on "brimstone, quicksilver, or litharge"—also discussed Paracelsus' theories and various methods of distilling chemical medicines. ${ }^{31}$

The German physician Valentine Russwurin was prominent amongst the immigrants spreading these new concepts. Described as a "doctor, alchemist, surgeon, lithotomist, and optometrist" in his 1574 letters of denization, Russwurin exemplified the link between alchemists and physicians in the Elizabethan period. ${ }^{32}$ Russwurin provides an excellent case study for Cecil's consultation with, and defence of, so called 'irregular' practitioners. As his gout became more and more debilitating, he turned to the alchemical polymath for treatment, sending Russwurin a sample of his urine. ${ }^{33}$ Many Paracelsian practitioners claimed to be able to diagnose through the chemical analysis of urine, a practice which continued until the end of the seventeenth century. ${ }^{34}$

Russwurin opened his diagnosis to Cecil with a long defence of his practice and of chemical medicine in general. In his defence, Russwurin attacked the medical establishment, amongst which, he claimed

from my first cominge into this lande unto this tyme, there hath not escaped, as I am credibly enformed; a meale or meeting, where any of the universitye doctors have bene present, wherin I have not bene backbytten, sclaundered and also impudently (saving y. L. honour) belyed ${ }^{35}$

\footnotetext{
30 Pelling, Medical Conflicts, p. 119.

31 William Bullein, Bulwarke of Defence Againste All Sicknes, London, 1562, p.10.

32 Denization of Valentine Rawsworme, 25 February 1574, Public Records Office of the United Kingdom, CPR Vol. 6 Elizabeth I (1572-1575), London, 1939, p. 261.

33 Valentine Russwurin to Cecil, undated, BL Lansdowne Vol. 101 no. 4.

${ }^{34}$ Allen G. Debus, Man and Nature in the Renaissance, Cambridge, 1978, p. 128.

${ }^{35}$ Russwurin to Cecil, Lansdowne Vol. 101, No. 4.
} 
According to Russwurin the university doctors objected to his lack of training in "Greciane or Aristoteticall philosophye". ${ }^{36}$ He appealed to Cecil, "who excelleth in all kindes of good learninge himselfe", to withhold judgement until he sees the effects of the treatment. ${ }^{37}$ Those university trained physicians who "are the trewe searchers of the secretes and mysteryes of nature", a common allusion to alchemy, were exempted from his attack. ${ }^{38}$ Russwurin argued that even those physicians who originally looked to banish chemical medicine had "by litle and litle to resorte to the preparers of suche medicines... to buye all the chymicall medicines that they can gett". ${ }^{39}$ This supports Charles Webster's claim that even members of the medical establishment were becoming increasingly reliant on chemical remedies. ${ }^{40}$

Through weighing Cecil's urine, Russwurin had determined that the cause of his gout was a problem with one of Cecil's alchemical systems. An excess of moisture

lyke a miste or fogge, threateneth here after as age shall encrease, a weaking not onely of the eye, but of the eares and of the memorye also ... Paracelsus calleth them Tartarical because they soone turne into a Tartar, they fall downe into the outtermoste partes, especially into the feete ... and there coagulating and waxing harde bredeth all those paynes. ${ }^{41}$

Russwurin informed Cecil that the disease would need to be treated with both internal and external medicines "bothe sortes spirituall, and not as Galenicall medicines be ... excellent extractiones, saltes, essences, tinctures, and maysteries of metalles, of precious stones of pearles and spices." ${ }^{\prime 2}$ These would cleanse the blood and reduce the pain of Cecil's gout.

Such was Cecil's trust in Russwurin's methods that he consulted with him about his aging mother, Jane Cecil. Informed that "your Lordship is desyrous also to understand whether your Lordship mother may recover her sight agayne", Russwurin declared himself

\footnotetext{
${ }^{36}$ Ibid.

${ }^{37}$ Ibid.

${ }^{38}$ Ibid.

39 Ibid.

${ }^{40}$ Webster, 'Alchemical and Paracelsian Medicine', p. 305.

${ }^{41}$ Russwurin to Cecil, Lansdowne Vol. 101, No. 4.

${ }^{42}$ Ibid.
} 
eminently qualified to deal with the problem. ${ }^{43}$ Russwurin agreed with the common sixteenth century notion that sight "cometh from the brayne", and that Jane Cecil's cataracts were blocking these emanations. ${ }^{44}$ Having allegedly restored around thirty patients' sight, Russwurin offered to enact an unspecified cure. Cecil took great care of his mother, now in her seventies and living in his manor in Stamford, and therefore must have had some confidence in the Paracelsian to even consult with him on the matter. ${ }^{45}$

Cecil's consultation is all the more remarkable given both Russwurin's background and his bitter public struggles with London's medical establishment. Russwurin recalled having recently cured in Hamburg "one Richarde Turner that was lunaticus [a lunatic]", and rather than receiving any reward he was accused of "the selfe same that nowe I am charged with". ${ }^{46}$ While Russwurin did not specify the charges, along with his mention of being maligned by "superficially learned doctores", it suggests that Cecil's undated consultation coincided with Russwurin's high profile trial on 22 April 1574 before the London Court of Aldermen. ${ }^{47}$ Just weeks after Russwurin was granted denizen status, the Company of Barber-Surgeons accused Russwurin of numerous examples of medical malpractice. Amongst the charges were the prescription of a chemical powder which caused his patients internal blistering, and of blinding a man suffering from cataracts. They claimed that Russwurin "put out his eyes cleane, and so deprived him of all his sight". 48

In total Russwurin stood accused of causing the death of at least twenty three of his patients "by his rustical dealings". ${ }^{49}$ The only account of the trial and Russwurin's supposed crimes survives in A Briefe and Necessarie Treatise Touching the Cure of the Disease Called Morbus Gallicus (1585), later published by one of the complainants, the surgeon William Clowes. ${ }^{50}$ He portrayed Russwurin as an unskilled charlatan, lacking in medical knowledge, who

43 Ibid.

44 Ibid.

45 Alford, Burghley, p. 227.

${ }^{46}$ Russwurin to Cecil, Lansdowne Vol. 101, No. 4.

${ }^{47}$ Russwurin to Cecil, Lansdowne Vol. 101 no. 4; William Clowes, A Briefe and Necessarie Treatise Touching the Cure of the Disease Called Morbus Gallicus, London, 1585, pp. 12-13.

${ }^{48}$ Clowes, $A$ Briefe and Necessarie Treatise, p. 11.

${ }^{49}$ Ibid., p. 11.

${ }^{50}$ Ibid. 
attempted to deceive his patients with lies and tricks of the hand. According to Clowes, at the trial only one man defended Russwurin, "one other proud bragger or single souled chirurgeon... a man of little skill, and lesse honestie". ${ }^{51}$ Describing Russwurin as "a wise Alchymist", this man is identified by a sixteenth century marginal note in Clowes' work as "John Hester Alchymist". ${ }^{2}$ That Hester-one of London's most respected distillers and a prolific author and translator of chemical medical texts-would support Russwurin, undermines the impartiality of Clowes' account. ${ }^{53}$ Neither Clowes, nor any other contemporary source reports the outcome of the case.

It is clear from Russwurin's mastery of Paracelsian medical theory that he was more than the ignorant charlatan portrayed by Clowes. Indeed Russwurin claimed that such distinguished European medical figures as Pier Andrea Mattioli, Johann Weyer, and Rembert Dodoens "have learned and sene at my hands suche thinges as all thyr lyfe they should never have found, neyther in Galene nor Avicenne". ${ }^{54}$ Curiously none of these men were well known for their Paracelsian sympathies. Weyer indeed described Paracelsus as an "insane man" and his followers as

the special slaves of arrogance, self-love, and vainglory, who can accomplish all things whatsoever by Stentorian cries, and by promises and sesquipedalian words, in perfect imitation of their master. ${ }^{55}$

While the reference was meant only to reassure Cecil, it at least demonstrates Russwurin's opinion of his own abilities.

Russwurin was not the only chemical physician whom Cecil consulted. Cecil's links to the Dutch astrologer, alchemist and physician, Eliseus Bomelius, are also intriguing. Having received a medical degree from Cambridge University, Bomelius initially enjoyed

\footnotetext{
51 Ibid., pp. 12-13.

52 Quoted in Deborah Harkness, “'Strange” Ideas and "English” Knowledge' in Pamela H. Smith, Paula Findlen (eds.), Merchants \& Marvels: Commerce, Science, and Art in Early Modern Europe, London, 2002, p. 146.

53 Webster, 'Alchemical and Paracelsian Medicine', p. 326-27.

${ }^{54}$ Russwurin to Cecil, Lansdowne Vol. 101, No. 4.

55 Johann Weyer, 'De Praestigiis Daemonum', John Shea (trans.), in George More and Benhamin Kohl (eds.), Witches, Devils, and Doctors in the Renaissance, Birmingham, 1991, p. 153.
} 
the patronage of James Blount, Lord Mountjoy. ${ }^{56}$ As Mountjoy is known to have been obsessed with alchemy, spending the family fortune searching for the philosopher's stone, Bomelius likely served Mountjoy in some alchemical capacity. ${ }^{57}$ By 1567 Bomelius had set up a successful London medical practice and gained prominence as both a Paracelsian physician and an astrologer. ${ }^{58}$ Archbishop Matthew Parker noted that "many have a wonderful confidence in hym and in his magicke" and the Protestant reformer Philip Melanchthon "hath in familiar letters praysed [him] highly for erudition and godlynes". 59

His success, however, brought him to the attention of the London College of Physicians, and in 1567 he was imprisoned for practicing medicine without a license. ${ }^{60}$ During his incarceration, Bomelius repeatedly appealed to Cecil for help, assuring him that Sir Thomas Smith considered his alchemical practice legitimate. ${ }^{61}$ Cecil wrote repeatedly to the College of Physicians on Bomelius' behalf. ${ }^{62}$ Why Cecil favoured Bomelius is unclear. According to Strype, Bomelius was the author of the astrological prediction about Elizabeth's marriage negotiations, dating from around this period, which survives in Cecil's papers. $^{63}$

After having consulted with both Cecil and the Archbishop of Canterbury regarding his astrological predictions of great upheaval in England, in late April 1570 Bomelius wrote to Cecil informing him that in

about a month hence I shall be enabled through your magnificence to devote my services and assistance to Her Royal Majesty, and point out a

\footnotetext{
${ }^{56}$ John Bennell, 'Bomelius, Eliseus (d. 1579)', Oxford Dictionary of National Biography, Oxford, 2004 [http://www.oxforddnb.com/view/article/2811].

${ }^{57}$ Robert Naunton, Fragmenta Regalia or Observations on the Late Queen Elizabeth, Her Times and Favourites, London, 1641, p. 37.

58 Bennell, 'Bomelius, Eliseus' (d. 1579)'.

59 Archbishop Matthew Parker to William Cecil, 3 April 1570, BL, Lansdowne Vol. 12. No. 79; Henry Bennet, A Famous and Godly History Contaynyng the Lyves and Actes of Three Renowned Reformers of the Christian Church, London, 1561, p. vi.

${ }^{60}$ Eliseus Bomelius to Cecil, May 27 1567, TNA, SP 12/42/69.

${ }^{61}$ Bomelius to Cecil, SP 12/42/69; Eliseus Bomelius to Cecil, 1567, TNA, SP 12/44/73; Eliseus Bomelius to Cecil, February 1568, TNA, SP 12/46/43.

62 Margaret Pelling and Francis White (eds.), 'BOMELIUS, Elisaeus \&c.', Physicians and Irregular Medical

Practitioners in London 1550-1640: Database, 2004, [http:/ / www.british-

history.ac.uk/report.aspx?compid=17251].

${ }^{63}$ Strype, Annals of the Reformation, Vol. 2, p. 23.
} 
way whereby these intestine evils may be healed, without any effusion of blood. ${ }^{64}$

However, "if Her Royal Majesty has no desire to avail herself of my art", Bomelius requested permission to work for the Russian Tsar Ivan IV (popularly known as Ivan the Terrible). ${ }^{65}$ Evidently this permission was granted, as on 2 June 1570 Bomelius was released, settling in Russia by the end of the year. ${ }^{66}$ Although Bomelius acquired enormous influence with the Tsar, he eventually fell victim to Ivan's paranoia, and was accused of treason and roasted at the stake in $1579 .{ }^{67}$

It is unclear whether, as Isabel De Madariaga claims, Cecil employed Bomelius as a physician. ${ }^{68}$ The physician's frequent appeals for Cecil's support and Cecil's letters to the College of Physicians on Bomelius' behalf certainly suggest that there was more to their relationship than is revealed by the existing sources. Cecil at least put some stock in Bomelius' astrological abilities, demonstrating the connection between astrological prognostication and medical treatment in the minds of contemporaries.

Even among the prominent orthodox physicians whom Cecil employed, many displayed a distinct interest in the new chemical therapies. William Paddy, Cecil's physician from 1594, would maintain a close friendship with both the Jacobean alchemical philosopher Robert Fludd and the German physician and alchemist Michael Maier. ${ }^{69}$ Utilising his prominent position in the College of Physicians, Paddy was instrumental in creating its official Pharmacopeia, which authorised the use of a number of chemical treatments. $^{70}$ While there is no record of the treatments that Paddy prescribed for Cecil, his subsequent record suggest that he would have been open to the use of Paracelsian

\footnotetext{
${ }^{64}$ Archbishop Matthew Parker to Cecil, 3 April 1570, BL, Lansdowne Vol. 12. No. 79; Eliseus Bomelius to Cecil, April 1570, reproduced in Joseph Hamel, England and Russia, London, 1854, pp. 203-205.

${ }^{65}$ Bomelius to Cecil, in Hamel, England and Russia, pp. 203-205.

${ }^{66}$ Isabel de Madariaga, Ivan the Terrible, New Haven, 2005, p. 254.

${ }^{67}$ Ibid., p. 323.

68 Ibid., p. 254.

${ }^{69}$ Both Fludd (Medicina Catholica, 1629) and Maier (Arcana Arcanissima, 1614) dedicated major works to Paddy. See Lauren Kassell, 'Paddy, Sir William (1554-1634)', Oxford Dictionary of National Biography, Oxford, Sept 2004; online edn, Jan 2008 [http://www.oxforddnb.com/view/article/21080].

70 Ibid.
} 
medicines. Amongst the collection of books bequeathed by Paddy upon his death in 1634 were five of Paracelsus' most influential works. ${ }^{71}$

Cecil's choice of William Gilbert as a physician is also indicative of his opinion of chemical medicine. Gilbert, who attended Cecil at his death, is best remembered for his great work De Magnete (1600), a natural philosophical treatise on the Earth's magnetism. ${ }^{72}$ While historians have traditionally placed Gilbert alongside Francis Bacon as a founding figure of modern science, recent studies have tended to place him within the context of renaissance magic. ${ }^{73}$ Rejecting Aristotle's view of the universe, Gilbert appealed to the authority of Zoroaster and Hermes Trismegistus. ${ }^{74}$ His theory was in essence complementary to alchemy as

Gilbert thought of attraction as a spiritual force, he held that the magnet had a soul (superior to man's soul), and he understood the Earth as mater communis in whose womb metals were formed ${ }^{75}$

This alchemical view of the growth of metals was prevalent during the sixteenth century and likely matched Cecil's own beliefs. ${ }^{76}$

Gilbert built up a successful medical practice in London during the 1570s, and served not only Cecil, but also the Earl of Leicester and other prominent figures at Elizabeth's Court. ${ }^{77}$ Thomas Fuller's report that Gilbert utilised chemical medicine, having "addicted himself to chemistry, attaining to great exactness therein" is supported by the alchemical notes and prescriptions of the Paracelsian apothecary Edward Barlow. ${ }^{78}$ Over the period from 1588-90, Barlow created a number of chemical medicines for Gilbert, and it is reasonable to assume that Gilbert administered some of these as Cecil's physician. ${ }^{79}$

\footnotetext{
${ }^{71}$ Webster, 'Alchemical and Paracelsian Medicine', p. 321.

72 Stephen Pumfrey, 'Gilbert, William (1544?-1603)', Oxford Dictionary of National Biography, Oxford, Sept 2004; online edn, Jan 2008 [http://www.oxforddnb.com/view/article/10705].

73 Paolo Rossi, 'The Scientist' in Rosario Villari (ed.) Baroque Personae, Chicago, 1995, pp. 267-68.

74 Ibid.

75 Ibid.

${ }^{76}$ Pumfrey, 'Gilbert, William'.

77 Ibid.

${ }^{78}$ Thomas Fuller, The History of the Worthies of England, London, 1662, p. 332.

79 Alain Besson, 'Classification in Private Library Catalogues of the English Renaissance, 1500-1640', Unpublished Phd Thesis, University College London, 1988, p 264; Charles Webster, 'Alchemical and Paracelsian Medicine', p. 323.
} 
Cecil's physician in the early 1580s, Hector Nunez, also consulted with Barlow for chemical medicines. ${ }^{80}$ In 1588 the navy approached Gilbert and four other physicians to administer a chemical therapy that would "have care of the helthe of the noblemen, gentlemen and others". ${ }^{81}$ Gilbert's involvement in the College of Physicians' controversial and unsuccessful first attempts to produce a pharmacopeia of chemical medicines in the early 1590s further demonstrated his interest in Paracelsian medicine

The numerous offers of chemical solutions to Cecil's medical problems demonstrate that his contemporaries knew of his fascination with chemical medicines. Whilst a great many of the suits made to Cecil for medical patronage have no surviving response (unsurprising given the paucity of Cecil's surviving outgoing correspondence) they nevertheless exemplify the type of medical therapies that suitors thought would interest Cecil. In 1583 Nicholas Gybbard wrote to Cecil claiming the ability to cure any illness, including Cecil's gout, using an alchemical tincture of gold. ${ }^{82}$ This Paracelsian treatment is reminiscent of the seventeenth century alchemist and physician Francis Anthony's popular panacea aurum potabile (drinkable gold). ${ }^{83}$ Far from an uneducated fraud, Gybbard was a respected physician, who possessed an extensive library of both Galenic and Paracelsian works, and had graduated as a licensed medical doctor from Oxford University. $^{84}$

In 1591 Henry Bossevyle, a recusant gentleman and sometime lawyer to the prominent Catholic Earls of Sussex, offered Cecil an alchemical cure for his gout. ${ }^{85}$ Cecil and Sir Francis Walsingham had previously suspected Bossevyle of smuggling alchemical

${ }^{80}$ Ibid; Read, Lord Burghley, p. 261.

81 The Privy Council to William Gilbert, 28 March 1588, John Roche Dasent (ed.), APC, Volume 16: A.D. 1588, London, 1897 , p. 5.

${ }^{82}$ Nicholas Gybbard to Cecil, 1583, BL, Lansdowne, Vol. 39, No. 53.

${ }^{83}$ F. V. White, 'Anthony, Francis (1550-1623)', Oxford Dictionary of National Biography, Oxford, Sept 2004; online edn, Jan 2008 [http://www.oxforddnb.com/view/article/590].

${ }^{84}$ R. T. Gunther, A History of the Daubeny Laboratory, Magdalen College, Oxford, London, 1904, pp. 383-6.

${ }^{85}$ Henry Bossevyle to Cecil, 11 April 1586, TNA, SP 12/188/11; Henry Bossevyle to Cecil, 1591, BL, Lansdowne Vol. 69, No. 60. 
gold into France to fund Catholic exiles. ${ }^{86}$ Bossevyle assured Cecil that the blistering of the skins caused by application of leather plasters soaked in "waters", likely an acid, would draw out the gout's "badde humore". ${ }^{87}$ He was confident that "when he is cured your Lordship [Cecil] schall se a difference betwene alcumists and phisicians, and then your Lordship maye bouldely deale with me". ${ }^{88}$ Bossevyle, not a marginal "odd foreigner" as the Lansdowne Catalogue dismisses him, hoped Cecil would part with the massive sum of $£ 300$ for the treatment. ${ }^{89}$ While it is to be hoped that Cecil ignored this gruesome 'cure', it is significant that suitors thought he would be receptive to these extreme chemical medicines.

Cecil's suitors did not limit themselves to offers of practical medical assistance: there are two lengthy manuscript treatises, focussing on the theoretical aspects of alchemical medicine, dedicated to Cecil. The first, Humfrey Lock's 'Collections on Alchemy', written to Cecil from Russia, probably in the early 1570s, consists of a collection of various alchemical works, prefaced by a dedicatory epistle to Cecil outlining alchemy's medical usages. The second, Samuel Norton's 'Summarie Collections of True Natural Magick' utilised mathematical and biblical arguments to first refute Galenic medicine, and then advocate Paracelsian medicine as the true successor of ancient Christian alchemical knowledge.

Until very recently, Lock has not been examined in any great detail. His name only occurs briefly either in studies of England's trade with Russia in the sixteenth century, or in catalogues of alchemical literature. ${ }^{90}$ It was only with Peter Grund's $2004 \mathrm{PhD}$ thesis "Misticall Wordes and Names Infinite": An Edition of Humfrey Lock's Treatise on Alchemy', expanded in a forthcoming book, that biographical details about Lock have

\footnotetext{
${ }^{86}$ Henry Bossevyle to Francis Walsingham, 13 February 1590, TNA, SP 12/230/71.

${ }^{87}$ Bossevyle to Cecil, Lansdowne Vol. 69, No. 60.

88 Ibid.

${ }^{89} \mathrm{Ibid}$; Ellis and Douce (eds.), A Catalogue of the Lansdowne Manuscripts, p. 131.

${ }^{90} \mathrm{~J}$. Hamel, England and Russia, London, 1854, p. 177; Robert Schuler, English Magical and Scientific Poems to

1700: An Annotated Bibliography, New York, 1979, p. 55.
} 
emerged. ${ }^{91}$ Whilst Grund provides useful biographical and sociohistorical context for the 'Collections', he primarily focussed on the sources and linguistics of the treatise itself. Grund demonstrated that 'Collections on Alchemy' consists primarily of a compilation of earlier alchemical texts, especially the writings of George Ripley. However, while Grund has noted that both Cecil and Elizabeth were "Two of the staunchest supporters of alchemical experimentation" and that the treatise would have been written in this context, an attempt to situate Lock within Cecil's alchemical patronage was outside his remit. ${ }^{92}$

Lock's background still resists research. Apparently unrelated to the prominent London family of poets, merchants and travellers of the same name, Lock first emerges in 1562 as the overseer, surveyor and chief carpenter at the construction of Upnor Castle in Kent. $^{93}$ In a letter to Cecil of 18 June 1562 regarding progress on the castle, Lock proposed that stone from the disused Rochester Castle could be used for the construction. He had clearly been in correspondence with Cecil for some time. ${ }^{94}$ Lock effectively managed the construction project since it began in 1560, because the castle's designer, Sir Richard Lee, the foremost English military engineer of the day, was preoccupied with the construction of the fortress at Berwick upon Tweed. ${ }^{95}$ However, according to the accounts of the site manager Richard Watts, Lock's interest waned and he only visited the site twice after $1564 .^{96}$

In 1567 Elizabeth sent Lock with others to Russia, in response to Tsar Ivan IV's request for an English architect who could "make castiles, townes, and palaces"..$^{7}$ Lock would later complain about his exile, and of false "freendes [in England] that brought me

\footnotetext{
${ }^{91}$ Peter Grund, “'Misticall Wordes and Names Infinite”: An Edition of Humfrey Lock's Treatise on Alchemy, with an Introduction, Explanatory Notes and Glossary', Unpublished PhD Thesis, Uppsala University, 2004; Peter Grund, "Misticall Wordes and Names Infinite" An Edition and Study of Humfrey Lock's Treatise on Alchemy, Medieval and Renaissance Texts and Studies, Tempe, Forthcoming 2010.

92 Grund, "Misticall Wordes and Names Infinite".

${ }^{93}$ Humfrey Lock to Cecil, 16 June 1562, TNA, SP 12/23/42.

94 Ibid.

${ }^{95}$ Marcus Merriman, 'Lee, Sir Richard (1501/2-1575)', Oxford Dictionary of National Biography, Oxford, 2004 [http://www.oxforddnb.com/view/article/16303]

${ }_{96}^{6}$ A. D. Saunders, Upnor Castle, London, 1967, pp. 6-7.

${ }^{97}$ Quoted in Hamel, England and Russia, p 177, date of 1567 given in N. N. Rubtsov, History of Foundry Practice in USSR, The Indian National Scientific Documentation Centre (trans.), New Delhi, 1975, p. 44.
} 
in distayne". ${ }^{98}$ However, it is not clear whether Lock went as a punishment or of his own accord. According to Mildred Wretts-Smith, many Englishmen travelled to Russia attracted by the higher wages offered there. ${ }^{99}$ His new employer certainly considered him a master craftsman, paying him 40 roubles annually, compared to 15 to 30 roubles a year for other craftsmen. ${ }^{100}$

Lock's unhappiness with the situation may have stemmed from his indebtedness to, and frequent conflicts with, the English merchants of the Muscovy Company. His initial complaint, outlined in a letter to Cecil of 20 May 1568, was that on arrival in Russia he had been compelled to purchase "a great deal of paltrye apparill” despite bringing over $£^{26}$ worth of clothes from England. ${ }^{101}$ Lock alleges that this gave the Russian Tsar the impression of

her highnes to be a deceaving and decembling prince, in that her majesty hath sent worthily commended by her highnes letters.... the verye oughtcasts of all ...not so able to live as to have on there back a good garment $^{102}$

Lock also criticised the dishonest business practices of the Muscovy company, especially their "gredy seking ...to bring certayne men that lyvid in Rusland into bondage", by which "the queenes highnes and your honors of the concell have sustaynyd ... more dyshonor than ever your shall recover ageyn by Rusland affayres". ${ }^{103}$ Thus began an acrimonious relationship between Lock and the English merchant community in Moscow that would haunt his time in Russia.

Lock turned to his contacts at the English Court, Cecil and Leicester, to rescue him from the situation. Appealing to Cecil's security interests, Lock first claimed that if he could

\footnotetext{
${ }^{98}$ Humfrey Lock, Dedicatory Epistle to Cecil, undated, BL, Sloane Papers 288, 23r-42v.

${ }_{99}$ Mildred Wretts-Smith, 'The English in Russia During the Second Half of the Sixteenth Century', Transactions of the Royal Historical Society, Vol. 3, 1920, p. 100.

100 There is no accurate way to convert this amount into contemporary English pounds.

${ }^{101}$ Humfrey Lock to Cecil, 20 May 1568, TNA, SP70/98 f. 62r.

102 Ibid.

${ }^{103}$ Humfrey Lock to Cecil, 1 July 1568, Sp70/100 f. 4r.
} 
caste the ffeare of god behynd me and desyre riches more than gods glory, I cold do ffor the Emperor suche things and make hym suche engynes for his warres that he might therby subdewe any prynce that wold stand agaynst him. Whiche devyces yf I wold make manyfest I cold have land and mony inough; but that goode is evill gotten, that pressyts a man downe in to hell ${ }^{104}$

Nicholai Rubtsov's identification of Lock as a cannon founder was possibly based on this letter. ${ }^{105}$ Lock also maintained that he "cold have done proffytable things in England abought the making of salt" but believed that another man would steal his invention, as Cecil and Leicester had given credit to unspecified baseless accusations against him. ${ }^{106} \mathrm{It}$ seems unlikely that Lock was referring to common salt, whose method of production was well known. Perhaps Lock was referring to Paracelsian medical salts. Regardless, Lock did not receive the desired response, as three years later he was still stranded in Moscow. Accused by the merchants as a "traytor, and an eniymye to me countrye, bycause I could not prase there evyll doings", on 19 May 1572 Lock wrote to Leicester begging for his good favour as in times past. ${ }^{107}$ Lock asked if Leicester and Cecil could convince the Queen to write a letter for his delivery out of Russia. ${ }^{108}$ Although he technically had free passage in Russia, Lock doubted whether he would be allowed to leave if the Tsar continued his ambitious building schedule.

It was Lock's situation in Russia, accused by the Muscovy Company as a traitor and desperate to return home, that motivated him to send Cecil an alchemical treatise. Grund has identified seven extant copies of the treatise, along with five extracts and abbreviations, making it difficult to establish which, if any, is original. None are in Lock's hand and only the alchemist and physician Simon Forman's copy of 1590 is dated. This chapter primarily relies on MS Sloane 299, seemingly the most compete version. ${ }^{109}$ The manuscript consists

\footnotetext{
104 Lock to Cecil, SP70/98 f. 64v.

105 N. N. Rubtsov, History of Foundry Practice, p. 44.

106 Lock to Cecil, SP70/98 f. 64v.

107 Humfrey Lock to Leicester, 19 May 1572, TNA, SP 70/123 f.149r.

108 Ibid.

${ }^{109}$ For a detailed comparison of the contents and provenance of the various versions see Peter Grund,

"Misticall Wordes and Names Infinite", pp. 6-12.
} 
of a dedicatory epistle to Cecil, followed by a lengthy technical treatise on transmutational and medicinal alchemy.

As most of the treatise has been identified as reproducing a range of earlier alchemical authorities, the marginal notes and dedicatory epistle provide more interesting information on Lock's intentions. From the outset Lock made the aim of his suit obvious, to return "him that now is far away, from his owne native lande, that wolde might gladly he were there, to labour with his hands". ${ }^{110}$ A marginal note in the treatise proper firmly establishes that Lock was referring to his time in Russia.

For when I compiled it I ment to have sent it into Ingland as a present \& mediator to help me home out of Russia, wherfor I made it the more darke that I might the sonner be sente for home for to doe it myselfe ${ }^{111}$

This note, one of the few that can definitely be ascribed to Lock, also demonstrates that he had understood that an alchemical treatise, written in obscure language, would be a suitable gift for Cecil. Lock anticipated that Cecil would find it sufficiently enticing to bring him home from Russia to fulfil his "darke" promises. The epistle also stressed the need for Cecil to bring Lock back to England to "put in practise the same things, that are written in this booke". ${ }^{112}$

Lock sought to differentiate himself from the other alchemists whom Cecil had patronised. He hoped that Cecil would ignore other alchemical proposals and be "from evil men protect, That runne abought deceiving such, As in them put there trust". ${ }^{113}$ Lock professed concern at Cecil's patronage of alchemical charlatans who, unlike himself, did not know "natures waies" or the "secret workings of the [philosopher's] stone". ${ }^{114}$ Like many alchemists of the period Lock tried to separate himself from the stereotype of the alchemical charlatan, arguing that those swindlers did not understand true alchemical philosophy. However, it also indicates that Lock was aware of Cecil's other alchemical

\footnotetext{
${ }^{110}$ Lock, 'Dedicatory Epistle'.

${ }^{111}$ Humfrey Lock, Quoted in Grund, “"Misticall Wordes and Names Infinite”, Unpublished PhD Thesis, p. 11.

${ }^{112}$ Lock, 'Dedicatory Epistle’.

113 Ibid.

${ }^{114}$ Ibid.
} 
patronage, which may have been well known even before Lock's move to Russia. Unlike the other pretenders seeking to take advantage of Cecil's fascination with alchemy, Lock claimed that only "I knowe it now as it was knowne to philosophers past". ${ }^{115}$ Lock's reference to alchemists who "In iron some do think to finde, The philosophers stone, And worke there one with great expense, Yet better let alone", may allude to Cecil's simultaneous patronage of William Medley's industrial alchemy, as detailed in Chapter four. ${ }^{116}$ Lock clearly recognised that he had significant competition for alchemical patronage.

Lock's epistle emphasised the medical, rather than financial, benefits to Cecil of his alchemical knowledge. In return for aiding his return to England, Lock promised to provide Cecil with "goulden drink I say, A medicine most of might... In repulsing that, that is in man, Wheron sickness often doth growe, That bringeth age in youthfull yeares". ${ }^{117}$ The treatise itself also contains details on the medical and pharmacological aspects of alchemy, "especially in that some of the transmutative elixirs are also said to be able to cure bodily diseases, and prolong life". ${ }^{118}$ While, according to Peter Grund, "the treatise seems to consider the medical virtues of elixirs as secondary" to the transformation of base metals into silver or gold, this could be considered merely a reflection of the source materials from which the treatise was compiled. ${ }^{119}$

There is no record of Lock expressing an interest in alchemy before his time in Russia. While his vague reference to salt production indicated some level of experience in industrial chemistry, the dedicatory epistle establishes that Lock developed his alchemical knowledge whilst in Russia. Despite his persistent complaints, Lock claimed not to repent "my longe absence, in vaine it have not bin, such knowledge here to me have come, As at

\footnotetext{
115 Ibid.

116 Ibid.

117 Ibid.

118 Grund, “Misticall Wordes and Names Infinite”, p. 29.

119 Grund, "Misticall Wordes and Names Infinite".
} 
home I have not seen". ${ }^{120}$ Where Lock acquired this knowledge is unclear. Alchemy had been a largely foreign concept in Russia, and is generally considered to have only become influential from the early seventeeth century. ${ }^{121}$ It is therefore likely that Lock would have obtained any alchemical knowledge from his fellow Englishmen in Moscow. Lock's position at the Tsar's Court certainly would have brought him into contact with Bomelius. Perhaps this connection convinced Lock that a demonstration of his alchemical knowledge would appeal to Cecil.

Humfrey Lock spent a considerable amount of time in compiling his 'Collections on Alchemy'. At over forty dense pages, it was a significant alchemical work, and its many contemporary copies show that it remained influential until the middle of the seventeenth century. Lock clearly had a reasonable expectation that his compilation, coupled with his epistle outlining the potential medical benefits of his return, would appeal to Cecil. From his correspondence, both in England and from Russia, it is not unreasonable to assume that Lock had developed a good understanding of the kind of service that would appeal to Cecil.

The alchemist Samuel Norton's medical treatise 'Summarie Collections of True Natural Magick', dedicated to Cecil, is a significant example of an attempt to appeal to Cecil utilising alchemical and Paracelsian knowledge. ${ }^{122}$ Despite this, the manuscript treatise has not previously been examined. Preserved in the Cambridge University Library, 'Summarie Collections' is not mentioned in Norton's Oxford Dictionary of National Biography entry, or any other lists of Norton's works. ${ }^{123}$ Whilst the manuscript is undated, it was certainly written after Cecil's ennoblement in February 1571. Norton's identification of

\footnotetext{
${ }^{120}$ Lock, 'Dedicatory Epistle'.

${ }^{121}$ N. A. Figurovski, 'The alchemist and physician Arthur Dee: an episode in the history of chemistry and medicine in Russia', Ambix, Vol. 13, 1965, p. 43.

122 Samuel Norton, 'Summarie Collections of the True Natural Magick grounded upon Principles Divine and from the Writinges of Hermes Trimegistus and others the Learned Auncients: conteining the true Philosophie and Physick drawen into commune places', undated, Cambridge University Library MS KK1.3 No.2.

${ }^{123}$ Scott Mandelbrote, 'Norton, Samuel (1548-1621)', Oxford Dictionary of National Biography, Oxford, Sept 2004; online edn, May 2008 [http://www.oxforddnb.com/view/article/20357].
} 
himself as "Samuel Rynevile and Norton" perhaps dates the manuscript to the 1590s when he wrote another alchemical work under the name "Samuel Rinvill, alias Norton". ${ }^{24}$ That he wrote the dedication from "my house at Ligh [Abbots Leigh in Somerset]", the family home, suggests that it was written after his father's death in $1584 .{ }^{125}$

Little is known of Norton's life. The great-grandson of the famous alchemist Thomas Norton, like Cecil he attended St. John's College, Cambridge—although some forty years afterwards. ${ }^{126}$ In July 1577 he dedicated to Queen Elizabeth 'A key of alchimie', a wide-ranging alchemical work, building on the alchemical philosophy of George Ripley, which claimed, under the influence of Norton's friend John Dee, that Elizabeth was on the verge of acquiring the philosopher's stone. ${ }^{127}$ It is unclear whether Norton ever won the royal patronage he sought. After his father's death, Norton became a prominent member of the Somerset gentry, and was active in local administration until his death in $1621 .{ }^{128}$

Despite Norton's university education, the medical philosophy outlined in the 'Summarie Collection' explicitly rejected Aristotle, and in turn Hippocrates and Galen, as "devoid and ignorant of this true magick natural where true physick is contained". ${ }^{129}$ Norton argued instead, that medicine should be based on "the primary and true physick of unite first revealed and had in the knowledge of Adam", reflecting the widespread belief that the biblical patriarchs had possessed great alchemical wisdom. ${ }^{130}$ According to Norton, a universe based on the three alchemical elements—-sulphur, mercury, and saltwas more compatible with both mathematic principles and the Holy Trinity than Aristotle's four elements. In doing so Norton was clearly influenced by Paracelsian ideas, however, he claimed that Hermes Trismegistus had been "inspired by God with this science...thousands

\footnotetext{
124 Norton, 'Summarie Collections'; Mandelbrote, 'Norton, Samuel'.

125 Ibid. [Italics added].

${ }^{126}$ Mandelbrote, 'Norton, Samuel'.

${ }^{127}$ Charles Nichol, The Chemical Theatre, London, 1980, p. 18. Parry, 'John Dee and the Elizabethan British Empire', p. 663.

128 Mandelbrote, 'Norton, Samuel'.

${ }^{129}$ Norton, 'Summarie Collections'.

130 Ibid.
} 
of yeeres before Paracelsus time". ${ }^{131}$ Scott Mandelbroke has noted Norton's determination in his other works to "reinterpret the native English alchemical tradition in a Paracelsian vein". ${ }^{132}$

According to Norton, all diseases resulted from imperfections of these three elements in the body. Extracts of certain vegetables, animals, stones, and metals could be

wrought by Art of fire that their purified Sulphurs Mercuries and Salts may be geeven to heale and help the imperfections of inward Sulphurs Mercuries and Salts declined from the harmonie of health. ${ }^{133}$

Given their use of alchemical techniques to restore the balance and unity of the body, Norton's treatments were clearly Paracelsian in nature. However, Norton also outlined "another way there is also much more philosophicall to come to the medicine". ${ }^{134}$ He then described how an alchemist could combine the male and female of each element through the process of "putrefaction" to create "a fixed oile which is the Elixir of life curing all diseases". ${ }^{135}$ Norton's directions for creating this elixir, the alchemist's philosopher's stone, are unusually comprehensible; they even include the proportions required. ${ }^{136}$ Norton therefore demonstrates both the intrinsic link between alchemy and Paracelsian medicine, and his determination to appeal to Cecil, a non-expert in practical alchemy.

Norton wrote the treatise with the intention of it being "presented, passed, and avouched for under the patronadge" of Cecil, knowing him to be "most singular and rare for learning". ${ }^{137}$ Significantly, Norton acknowledged that "although my good lord, you are [academia's] most cheefe piller and supporter, I feare not your parcialite". ${ }^{138}$ Although Norton denied Aristotelian learning, he remained confident that his alchemical understanding of nature, reinforced with biblical teaching, would appeal to Cecil. Norton concluded his dedication by describing

\footnotetext{
131 Ibid.

132 Mandelbrote, 'Norton, Samuel (1548-1621)'.

${ }^{133}$ Norton, 'Summarie Collections'.

${ }^{134}$ Ibid.

135 Ibid.

${ }^{136}$ Ibid.

${ }^{137} \mathrm{Ibid}$.

138 Ibid.
} 
Another work of mine owne practice containing great and true secrets after the doctrine of our father Hermes theorick is redy likewise to presse into your honors presence...whiche seene, I hope your lordship shall see that the truth of the ancient magick natural is not at this day unknown and unpractised among the serchers and studiers of truth. ${ }^{139}$

It is unclear whether Norton ever sent Cecil this second treatise. However, it is apparent that a number of Norton's alchemical works have not survived, including 'The Flower of True and Auncient Physick and Phiosophie', mentioned in this treatise. ${ }^{140}$

The extent of Cecil's relationship with Norton is unknown. Previous historians have not established any link between them, nor is there any extant correspondence between the pair. Norton may have appealed to Cecil based purely on his contemporary reputation. What is clear, however, is that this reputation suggested that Cecil would be interested in a treatise that combined Paracelsian and more traditional alchemical ideas, even though it involved a rejection of classical authorities.

Whilst a lack of evidence about Cecil's medical treatment makes it difficult to analyse his medical patronage, the case studies examined in this chapter strongly suggest that he favoured chemical medicine. Cecil's career certainly came at a time of increasing alchemical influence in medical practice. Paracelsian physicians, basing their practice on an alchemical understanding of both nature and the body, began to rival establishment Galenic physicians. Cecil's consultation with two prominent and controversial Paracelsians, Valentine Russwurin and Eliseus Bomelius, demonstrates at the very least a readiness to try these new alchemical methods. Even amongst Cecil's more conventional physicians, such as William Paddy and William Gilbert, there was a willingness to make use of chemical treatments.

A number of suits demonstrating medical knowledge also support the conclusion that chemical medicine interested Cecil. When suitors such as Nicholas Gybbard and

\footnotetext{
${ }^{139}$ Ibid.

140 Ibid.
} 
Henry Bossevyle suggested practical chemical solutions to Cecil's medical problems, especially his notorious gout, they did so in the clear expectation that he would consider their offers. These men, both of some local standing, would have known of Cecil's interests by reputation. Likewise, Humfrey Lock and Samuel Norton's treatisesdemonstrations of a theoretical understanding of alchemical medicine-were aimed at a man who believed in alchemical principles that had both medicinal and non-medicinal applications.

Whilst Cecil was an important patron of alchemy in his own right, in his role as a government minister he orchestrated some of the most historically significant alchemical projects in the Elizabethan period. To Cecil these projects were coherent attempts to solve urgent national problems through alchemical transmutation. Chapter three therefore examines Cecil's efforts to utilise alchemy as a solution to crises in Crown finances. 


\section{Chapter Three: Alchemy and Crown Finances}

Elizabeth's finances were under considerable pressure during two periods. The first, in the years immediately after her accession to the throne, from 1558 to 1568, saw the Crown, faced with a hostile France, having to deal with a legacy of inflation and debt. During the second, from the late 1580s to the end of her reign, war with Spain stretched the normally frugal monarch's finances almost to breaking point. During both periods Cecil played a central role in attempts to stabilise Crown costs and increase Crown revenues. Although the Earl of Winchester-described by A.G.R. Smith as "one of the great administrators of Tudor England"-acted as Elizabeth's Lord Treasurer until 1570, by the time of her accession the venerable councillor was in his mid eighties. ${ }^{1}$ As a result, his influence was much diminished even before Elizabeth dismissed him as speaker of the House of Lords on account of "the Decay of his Memory and Hearing, Griefs accompanying hoary Hairs and old Age". 2 With Winchester's star waning, Cecil, as the Queen's Principal Secretary, demonstrated a considered concern for the Crown's finances, playing a central role in obtaining essential subsidies from Parliament. ${ }^{3}$

The debasement of the coinage during the first half of the sixteenth century caused the Elizabethan government enormous problems. War with France in the 1540s had left England in enormous debt, and so under Henry VIII and Edward VI, the treasury employed an old trick in order to restore the royal finances: reducing the precious metal content of English coins to extract increased revenue from existing gold and silver stocks. ${ }^{4}$ The treasury's overzealous activities during the Great Debasement, as historians have termed it, fuelled the inflation that plagued sixteenth century England. ${ }^{5}$ At the same time the massive influx of Spanish silver from the New World decreased the value of both the

\footnotetext{
1 A. G. R. Smith, The Government of Elizabethan England, London, 1967, p. 52.

2 Anon., Journal of the House of Lords: Volume 1: 1509-1577, London, 1802, p. 637.

${ }^{3}$ Graves, Burghley, p. 42.

${ }^{4}$ C. E. Challis, The Tudor Coinage, Manchester, 1978, pp. 81-111.

${ }^{5}$ Ibid.
} 
metal and European currencies, further fuelling inflation. In the early period of Elizabeth's reign the Treasury's attempts to deal with inflation by recalling the debased coinage and issuing restored coins increased their requirement for precious metals.

During the comparatively peaceful mid period of Elizabeth's reign, the government subsisted on a relatively frugal budget. Royal servants were often rewarded with grants of either land or monopolies, and the Queen's household budget remained remarkably stable. Indeed, historians such as Penry Williams have questioned the Elizabethan government's financial management, with only small rises in real Crown rents over the Queen's reign and little effort to maximise other income streams, despite high levels of inflation. ${ }^{6}$ The Crown's chief financial strength was Elizabeth and Cecil's tight control of expenditure. ${ }^{7}$ However, with the outbreak of war with Spain in 1585 expenses skyrocketed. Whilst Cecil used various methods to maximise Crown revenue in the period, such as the reformation of the inefficient and unpopular system of purveyance, the government still relied upon politically unpopular measures such as parliamentary subsidies, forced loans and the sale of swathes of Crown lands. ${ }^{8}$

Cecil turned to alchemical speculation in order to stabilise Crown finances during these two periods of extreme financial strain. This chapter analyses three of those projects: Crown patronage of Cornelius de Lannoy's attempts at transmutation from 1565 until 1567; Cecil and the Queen's efforts to convince the alchemist Edward Kelley to return to England from 1588 until 1593; and finally the government's attempts to profit from Roloff Peterson's alchemical materials between 1593 and 1597. By examining Cecil's integral role in these schemes, this chapter argues that he saw the profits from alchemy as having genuine potential to aid Crown finances.

\footnotetext{
${ }^{6}$ Penry Williams, The Tudor Regime, Oxford, 1979, pp. 70-76.

${ }^{7}$ Ibid.

${ }^{8}$ Ibid.
} 


\section{Cornelius de Lannoy}

On 12 January 1567 Cecil recorded in his diary that a Cornelius de Lannoy had been imprisoned for "abusyng the Q. Majesty in Somerset Houss in promising to make the Elixar". ' Less than a month later on 10 February, Cecil wrote a final note: "Cornelius de la Noye, an alchymist, wrought in Somerset House, and abused many in promising to convert any metall into Gold". ${ }^{10}$ His displeasure is palpable. Despite Cecil mentioning him twice in his diary, normally reserved for matters of state importance, Elizabeth and Cecil's patronage of the alchemist Cornelius de Lannoy has largely escaped historians' attention. When examined, the episode has been consistently misinterpreted. A number of historians have considered de Lannoy's importance only in relation to the English production of glass, with J. S. Lewis even stating that de Lannoy "came to England, at the invitation of the Government, to teach the art of glass-making". 11 Those historians that have recognised de Lannoy's role as an alchemist, such as C. J. S. Thompson and Charles Webster, have provided insubstantial and often inaccurate descriptions of his activities. ${ }^{12}$ Whilst Deborah Harkness' The Jewel House (2007) acknowledged Cecil's key role in the project, her account of the project is brief. Harkness' use of the Calendar of State Papers, Domestic Series, of the reigns of Edward VI, Mary, Elizabeth, 1547-1580 (1856) has also led her to repeat some of its errors in dating and interpretation. ${ }^{13}$

\footnotetext{
${ }^{9}$ William Cecil, 'Notes of Queen Elizabeth's Reign by the Lord Treasurer Burleigh' in William Murdin (ed.), A Collection of State Papers Relating to Affairs in the Reign of Queen Elizabeth, From the Year 1571 to 1596, London, 1759, p. 763; De Lannoy was alternatively referred to by his Latinised name, Cornelius Alneto. For the purpose of clarity I will use the name de Lannoy throughout. ${ }^{10}$ Ibid.

11 J. S. Lewis, Old Glass, London, 1939, p. 35.

12 C. J. S. Thompson, The Lure and Romance of Alchemy, London, 1932; Webster, Health, Medicine and Mortality, p. 307.

${ }^{13}$ Harkness dates Armigal Waad's letter to Cecil, detailing plans to bring de Lannoy to Court to see the Queen, to 28 May 1567, as per the calendar. However, the manuscript itself does not give the year it was written, and its contents are much more consistent with a dating of 1566. See Armigal Waad to William Cecil, 28 May 1566, TNA, SP 12/42/70.
} 
De Lannoy first came to the attention of Cecil in December 1564, writing to him from Bruges in the Low Countries. ${ }^{14}$ Little is known of de Lannoy's background, aside from his claim to have attended university in Poland. ${ }^{15}$ Careful to distinguish himself from "those imposters and cheats...whom his sect deem worthy of extreme punishment", de Lannoy offered to "make every year 50,000 marks of pure gold, besides other metals, and diamonds, emeralds, and other precious stones". ${ }^{16}$ To do so de Lannoy claimed he would use the art created "by the leaders of the Egyptians, Arabs, Persians, and Israelites called Boarhchadamia[Voarchadumia]". ${ }^{17}$ In referencing Johannes Pantheus' influential Voarchadumia Contra Alchimiam (1530), de Lannoy, like Francis Thynne, used Cecil's knowledge of these influential occult tracts to differentiate himself from mere amateur conmen. Significantly, de Lannoy claimed to be able to distil a substance called "pantaura having the virtues of anima mundi for healing diseases instantly". ${ }^{18}$ The medical benefits of de Lannoy's proposal would have been especially appealing to Cecil, who already suffered from gout.

The real appeal of de Lannoy's proposal, however, was its financial potential. During the 1560s the treasury struggled with the debts of Mary's reign, and the Spanish imposition of punitive customs duties in Antwerp had severely affected England's vital cloth trade. ${ }^{19}$ De Lannoy's proposal could solve the treasury's woes though the creation of gold on a massive scale. The 50,000 marks, or $£ 33,000$, of gold which he offered to create annually equalled almost a sixth of the Crown's ordinary revenue. ${ }^{20}$ The offer was simply too good for Cecil to resist. By February 1565, presumably having received an encouraging response from Cecil, de Lannoy wrote two letters to the Queen further outlining his

\footnotetext{
${ }^{14}$ Cornelius De Lannoy to William Cecil, 22 December 1564, in Joseph Stevenson (ed.), CSPF 1564-5, London, 1870, p .267.

${ }^{15} \mathrm{Ibid}$.

${ }^{16}$ Ibid.

17 Ibid.

18 Ibid.

${ }^{19}$ Read, Secretary Cecil, p. 295.

${ }^{20}$ Williams, The Tudor Regime, p. 71.
} 
credentials, promises and conditions. ${ }^{21}$ These included his monopoly over his process and the Crown's payment for all his materials. De Lannoy requested an enormous annuity of $£ 250$ to sustain him during the three years and four months needed to perform his promises. ${ }^{22}$ As a demonstration of his good faith, in July de Lannoy wrote the Queen a treatise, Epistola de Conficiendo Devino Elixire, sive Lapide Philosophico, describing his process. ${ }^{23}$

The impoverished Elizabethan government bargained de Lannoy down to a still significant annual pension of $£, 120$ and installed him, and a costly alchemical laboratory, in London's Somerset House. ${ }^{24}$ By August 1565 Armigil Waad, Cecil's agent assigned to supervise de Lannoy, gauged the initial costs at around $f 600 .^{25}$ Despite the Crown's generosity, de Lannoy complained of the poor quality of English glassware and pottery, as the Englishmen could not "fassion ther stuff to make the same to susteyne the fourc of his great fyers" ${ }^{26}$ Waad also feared that as de Lannoy and a man known only as the 'Cypreyan', were about to make a "great perchase" of land in Pomerania, the alchemist would be diverted from his work. ${ }^{27}$ To avoid this Waad suggested that "he wear putt in sume generall cumfort of some place to be provided for him here in England...if he do his busyness he shall deserve mych more", ${ }^{28}$

Despite the enormous costs and initial setbacks, both Cecil and Waad remained hopeful of success. Cecil's friends, both at home and abroad, also held high hopes for de Lannoy's process, by now widely known throughout Europe. In October 1565 Richard Eden wrote to Cecil from France, rejoicing to hear that a great philosopher now worked for the Queen. Eden wished the Queen and Cecil the best in their alchemical endeavours, praying

${ }^{21}$ Cornelius de Lannoy to Queen Elizabeth, 7 February 1565, TNA, SP 12/36/12; Cornelius de Lannoy to Queen Elizabeth, 9 February 1565, TNA, SP 12/36/13.

22 Ibid.

${ }^{23}$ This work survives in the sixth volume of Theatrum Chemicum (1661). See Cornelius Alvetanus, 'Epistola de Conficiendo Divino Elixire, Sive Lapide Philosophico', in Lazarus Zetzner, Theatrum Chemicum, Strasbourg, 1661.

${ }^{24}$ Armigil Waad to Cecil, 7 August 1565, TNA, SP 12/37/3.

25 Ibid.

${ }^{26} \mathrm{Ibid}$.

27 Ibid.

${ }^{28} \mathrm{Ibid}$. 
god send it her majesty as trouly as I belevie the possabilitie to be trewe and as I judge her most woorthy so excellent a gyfte of god: Wherof I wolde write more unto your L[ordship] if I knew howe it wolde betaken ${ }^{29}$

The date of the letter leaves little doubt in identifying the "greate philosopher" as Cornelius de Lannoy.

The anticipation of de Lannoy's imminent success dissuaded Cecil from encouraging other alchemical hopefuls. In 1565, Thomas Charnock, a Somerset alchemist of some local repute, composed "A Booke Dedicated unto the Queenes maiestie", hoping to persuade the Queen to finance four alchemical works in the Tower. ${ }^{30}$ Charnock was disappointed, however, because after delivering the book to Cecil he discovered that

the Quene and hir counsell had set goone a work in Somerset place in London before I came and had wrought there by the space off one yere therefore my booke was layde a syde ffor a tyme : // and was put in the Queenes librarie ${ }^{31}$

A century later, Elias Ashmole, the celebrated antiquary, politician and student of alchemy, would look in vain for the book in the remnants of the Queen's Library. ${ }^{32}$ The book was assumed lost until its rediscovery in Cecil's papers in the Lansdowne collection in the 1970s. ${ }^{33}$ Charnock's assumption that the Queen was distracted by de Lannoy's work in Somerset House may have been correct. He may even have been told as much by Cecil upon delivery of his book. Either way, such was Cecil's interest in alchemy that he kept the book in his personal papers: the front page bears the evidence of its ownership, inscribed "William Burghleigh de B". ${ }^{34}$

The first signs of trouble with de Lannoy's project came to Cecil with news of a bond between the alchemist and Princess Cecilia of Sweden, also living in Somerset House. The Princess had travelled to England in order to further marriage negotiations between

${ }^{29}$ Richard Eden to Cecil, 12 October 1565, TNA, SP 70/80/123.

30 Allan Pritchard, 'Thomas Charnock's Book Dedicated to Queen Elizabeth', Ambix, Vol. 26, No. 1, 1979, pp. 56-72.

31 Ibid., p. 56.

32 Thomas Charnock, quoted in Pritchard, 'Thomas Chanock's Book', p. 57.

33 Pritchard, 'Thomas Chanock's Book', p. 57.

${ }^{34}$ Ibid. 
Elizabeth and her brother King Eric XIV of Sweden. However, she had only succeeded in accruing truly enormous debts. ${ }^{35}$ Hounded by her creditors, Cecilia turned to de Lannoy for an alchemical solution. The bond pledged de Lannoy to lend the Princess $£_{1} 10,000$, presumably created through his alchemical process, which Cecilia promised to repay with twelve yearly payments of one thousand pounds. ${ }^{36}$ Cecil, obtaining a copy of this bond, resolved to keep a tighter watch on the troublesome alchemist, lest de Lannoy divert his efforts away from his undertaking for the Queen.

De Lannoy and the Princess remained undeterred. Thinking to conceal their communication, they exchanged letters through Cecilia's chaplain Dr. Olaf. They had, however, underestimated the extent of Cecil's intelligence network. From January through March 1566 Cecil's spies intercepted and copied almost twenty letters between the pair. ${ }^{37}$ De Lannoy's pleas that "she must read secretly and burn" his letters were futile. ${ }^{38}$ Well aware of de Lannoy's duplicity, Cecil had little faith in his promises "to testify by deeds that he is one of Her Majesty's most faithful servants", or sympathy with his complaints of interference in his process. ${ }^{39}$

Meanwhile, an incident involving the "immoral overtures" of one of Waad's men, a Mr. West, towards one of de Lannoy's wife's maidservants had caused unbearable tension at Somerset House. ${ }^{40}$ Waad reported that de Lannoy "seems more and more to take to heart this lately discovered act, and can by no means abide West, the sight of whom stirreth up his colere". ${ }^{41}$ Perhaps de Lannoy believed that West was disturbing the pure moral atmosphere supposedly required for transmutation. By mid February 1566 Waad was sure that de Lannoy planned to flee to Middelburg in Zealand, taking Princess Cecelia with him. There was, however, no suggestion that de Lannoy needed to escape because he could not

\footnotetext{
${ }^{35}$ Ethel Seaton, Queen Elizabeth and a Swedish Princess, London, 1926, pp.15-23.

36 Bond between Cornelius de Lannoy and Princess Cecilia, 20 January 1566 in S. R. Scargill Bird (ed.), CMS.

Vol. 1: 1306-1571, London, 1883, p. 325.

${ }^{37}$ Scargill Bird (ed.), CMS. Vol. 1: 1306-1571, London, 1883, pp. 325-337.

38 Armigil Waad to Cecil, 24 February 1566 in Scargill (ed.), CMS, Vol. 1, p. 328.

${ }^{39}$ Cornelius de Lannoy to Queen Elizabeth, 15 February 1566 in Scargill (ed.), CMS, Vol. 1, p. 327.

${ }^{40}$ Cornelius de Lannoy to Cecil, 15 February 1566 in Scargill (ed.), CMS, Vol. 1, p. 326.

${ }^{41}$ Armigil Waad to Cecil, 15 February 1566 in Scargill (ed.), CMS, Vol. 1, p. 326.
} 
perform alchemy. Rather, Waad believed that he "intends to offer the Queen a sum of money to let him off his first bargain". ${ }^{2}$

Not willing to lose de Lannoy, Cecil ordered him detained in Somerset House, much to the alchemist's chagrin. ${ }^{43}$ De Lannoy wrote to Cecil "overwhelmed with grief that their great and glorious design should have fallen into such grave suspicion" and promised not to engage in any further communication with Princess Cecilia. ${ }^{44}$ De Lannoy soon broke his promise. Due to her increasingly dire financial situation, Cecilia entreated him to lend to her $f^{3}, 000$ — equal to only half her debts—and pledged her dowry for a further payment of $£ 10,000{ }^{45}$ Promising the money by May, de Lannoy finalised his escape plans, telling Cecilia "that he has undertaken in earnest the matter known to her". ${ }^{46}$

Waad, whose spies informed him of de Lannoy's plans, knew that de Lannoy planned an escape to Middelburg "where orders geven for an howse fytt for his perpose from when he will satisfie the Quenes majesty and the lady Cecilia."47 Waad also accused de Lannoy of having lied "to her majestie at her being with him at Somersett place". ${ }^{8}$ That the Queen would consult with the alchemist gives some indication of the project's importance. It is also significant that rather than having given up on de Lannoy's alchemical promises, Waad believed that he had already created the alchemical elixir, and planned to take it with him. Indeed, Waad argued that if de Lannoy was caught during his escape "the apprehension of him in thissort wilbe greatly advantageous for her majesty ffor that with one lab[ou]r her majesty shall come by the art and the thing it selph[the elixir]". ${ }^{49}$

It is unclear if Cecil agreed with Waad's plan, but the potential of de Lannoy's escape clearly concerned him. A letter from Waad to Cecil dated 28 May detailed hurried plans to "putt back all other boats that may happen to resort hither for any ill purpose

\footnotetext{
42 Ibid.

${ }^{43}$ Cornelius de Lannoy to Cecil, 17 February 1566 in Scargill (ed.), CMS, Vol. 1, p. 327.

${ }^{44}$ Ibid.

45 Princess Cecilia to Cornelius de Lannoy, 2 March 1566 in Scargill (ed.), CMS, Vol. 1, p. 330.

${ }^{46}$ Cornelius de Lannoy to Dr. Olaf, 14 March 1566 in Scargill (ed.), CMS, Vol. 1, p. 331.

${ }^{47}$ Armigil Waad to Cecil, 7 March 1566, TNA, SP 12/39/39.

${ }^{48} \mathrm{Ibid}$.

${ }^{49}$ Ibid.
} 
coloring the bussynes in sort as you honor did prescibe this day". ${ }^{50}$ Cecil had sent a Mr. Holcroft with three of his own men to supervise de Lannoy's transport to Court to explain his delays to the Queen. De Lannoy planned to send a servant ahead with letters "sych as he sayd he would have all persons ignorant of but her majesty". ${ }^{51}$ Waad's frustation with the alchemist had reached breaking point; he was sure that de Lannoy, who was "stout beyond all measure and speaketh words every inch of a foote and a half long", would merely blame his failure on imagined injuries done to him. ${ }^{52}$

De Lannoy's attempts at self-vindication failed and by July 1566 Cecil had incarcerated him in the Tower of London. Unsure of his future and stalling for time, he wrote desperate letters to the Queen, Cecil and the Earl of Leicester, who had also involved himself in the scheme. ${ }^{53}$ In response to accusations that he had attempted to escape with the elixir, de Lannoy maintained that his process had so far been unsuccessful, due either to the interference of wicked men or some minor error on his part. ${ }^{54}$ Nevertheless he insisted that if he was allowed to write to his friends for help, he would still be able to fulfil his promises. In order to demonstrate the value of his alchemical expertise he argued that his process, when perfected, would create a "medicine" capable of producing over thirty million times its own weight in gold. ${ }^{55}$

On 15 July 1566 Cecil and Leicester sent Waad to examine de Lannoy in the Tower. Waad reported that when accused of "often and intollerable dilaies and trifling with her highnes" and the deliberate "sincopation of the woork", de Lannoy admitted having made mistakes, but only because of the demands of haste from the Queen, Cecil

\footnotetext{
50 Armigil Waad to Cecil, 28 May 1566, TNA, SP 12/42/70.

${ }^{51} \mathrm{Ibid}$.

52 Ibid.

53 Cornelius de Lannoy to Queen Elizabeth, 1 July 1566, TNA, SP 15/13/23; Cornelius de Lannoy to Cecil and Leicester, 19 July 1566, SP12/40/32I.

54 Cornelius de Lannoy to Queen Elizabeth, 1 July 1566, TNA, SP 15/13/23.

${ }^{55}$ Ibid.
} 
and Leicester. ${ }^{56}$ De Lannoy promised that with a month's respite he would fulfill all of his former promises. ${ }^{57}$ Cecil, however, had found further evidence of the alchemist's duplicity. According to Waad, de Lannoy had attempted to deceive Cecil and the Queen by omitting "that passage in her majestys book toward the end wher mention is made of the mercuries of gold and silver" in order to disguise the progress of the work. ${ }^{58}$

Charging de Lannoy with having therefore "greatly abused her majesty", Waad demanded to see the original copy of the book, so they could learn the extent of his omissions. ${ }^{59}$ The alchemist explained that he had brought no such book with him and he had written the Queen's copy from memory. Calling de Lannoy's bluff, Waad insisted that he "shuld perform the same by memory doubting not but that he could doo yt nowe aswell as then". ${ }^{60}$ Presumably he failed to do so, as Waad suggested to Cecil that de Lannoy's wife be allowed to leave England, so that "Cor[nelius] would then think his case disperat and would conclud the sooner one way or an other". ${ }^{61}$

By August 1566 neither Cecil nor the Queen trusted the Dutch alchemist. They were sure that he would attempt to escape with the profits of the Queen's investments but still did not doubt the legitimacy of his process. After leaving the distressed alchemist to stew for over a month, on 23 August Cecil wrote to Waad and Sir Francis Jobson (the Lieutenant of the Tower), ordering him to arrange the immediate resumption of de Lannoy's alchemical operations, this time from within the secure confines of the Tower. ${ }^{62}$ Waad reported that a small sum of money would be required for provisions, which was promptly provided. ${ }^{63}$

From this point onwards there are few records of de Lannoy's activities. It appears that he continued to deceive Cecil and the Queen, and that by early 1567 even Cecil's

\footnotetext{
${ }^{56}$ Armigil Waad to Cecil and Leicester, 15 July 1566, TNA, SP 12/40/28.

${ }^{57}$ Ibid.

58 Ibid.

${ }^{59}$ Ibid.

${ }^{60}$ Ibid.

${ }^{61}$ Ibid.

${ }^{62}$ Armigil Waad and Sir Francis Jobson to Cecil, 26 August 1566, TNA SP 12/40/53.

${ }^{63}$ Ibid.
} 
patience had been exhausted. Desperate, de Lannoy petitioned Cecil, on 14 February, promising to transmute lead into gold with only a further two days work. ${ }^{64}$ Evidently Cecil was not appeased, as on 13 March the alchemist repeated the same promises to both Leicester and the Queen. ${ }^{65}$ It was of no use-by this point de Lannoy had sealed his fate.

A letter from Barbara de Lannoy, the alchemist's wife, to Leicester, unexamined by previous historians, reveals that the alchemist remained imprisoned long after the project's failure. Whilst the letter is undated, she wrote to Leicester after Cecil's ennoblement in February 1571, begging that her "poore husbande may be delyvered oute of his most miserable captivitie and longe imprysonment" so that they could return to their native country. ${ }^{66}$ Her previous appeals to Cecil had been unsuccessful, as he remained "displeased in that my poore husband had spent the Quenes Majestys money". ${ }^{67}$ However, Barbara claimed that if "all our moveables and goods forcybly taken from us" had been sold for their real value, they would have covered the Queen's expenses. ${ }^{68}$ As there is no record of the alchemist's release, it is quite possible that de Lannoy passed his remaining days incarcerated in the Tower.

One might expect that de Lannoy's deception would dissuade Cecil from the reliability of alchemical projectors. However, while the entire debacle may have dampened the Queen's enthusiasm for alchemical projects, Cecil remained optimistic about the prospect of transmutational success. A year later, with de Lannoy still imprisoned in the Tower, Cecil wrote to the English ambassador to France, Sir Henry Norris, regarding a letter he had received from an Italian alchemist living in Paris. Despite having "earnestly moved her Majesty to have adventured some small piece of Money upon such a Man”,

\footnotetext{
${ }^{64}$ Cornelius de Lannoy to Cecil, 14 February 1567, BL, Lansdowne Vol. 9 No. 53.

${ }^{65}$ Cornelius de Lannoy to Queen Elizabeth and Leicester, 13 March 1567, TNA, SP 12/42/30.

${ }^{66}$ Longleat House, The Dudley Papers, MS DUI/f.209r.

${ }^{67}$ Ibid.

${ }^{68}$ Ibid.
} 
Cecil could not convince the Queen, as she would "in no wise hear of any such offers, which she thinketh are but chargeable without fruit". ${ }^{69}$

The de Lannoy project from 1565-1567 demonstrates the close connection between Crown finances and alchemical projects. When Cecil learnt of de Lannoy's escape attempts, Waad assured him that the alchemist had already created the alchemical elixir and intended to keep the benefit for himself. ${ }^{70}$ Thus, when Cecil put de Lannoy in the Tower it was not to punish failure, but to ensure that the Queen, rather than others, would profit from a successful transmutation that Cecil continued to support and subsidise. To Cecil, the collapse of the project was the fault of de Lannoy's dishonesty, arrogance and greed. Therefore, Cecil's disgusted diary entries should not be taken as disillusionment with alchemy, rather as anger against an alchemist who would dare deceive the Queen.

\section{Edward Kelley}

The two decades following the failure of de Lannoy's attempts at transmutation were relatively prosperous for the Elizabethan treasury. In his opening speech to the 1576 parliament, Chancellor of the Exchequer Sir Walter Mildmay declared that the kingdom had cleared the "great and weighty debt" accumulated in the reigns of Henry, Edward and Mary. ${ }^{71}$ Whilst this was an exaggeration, the stabilisation of the English currency and the absence of expensive Continental wars had eased the government's financial concerns. Moreover, Elizabeth received unprecedented peacetime subsidies, and kept a tight rein on expenditure, bringing stability to the Crown's finances. ${ }^{72}$ The outbreak of war with Spain in 1585 transformed the situation. Spain was a global empire, with wealth and resources far beyond those of England, and the demands of war stretched government finances to their

\footnotetext{
${ }^{69}$ William Cecil to Sir Henry Norris, 1568, in Anon., Cabala, Sive Scrinia Sacra: Mysteries of State and Government in Letters, London, 1691, p. 139.

70 Waad to Cecil, SP $12 / 39 / 39$.

${ }^{71} \mathrm{Sir}$ Walter Mildmay to the House of Commons, 1576, quoted in Nares, Memoirs of the Life and Administration, Vol. 3, p. 64.

${ }^{72}$ T. A. Morris, Tudor Government, London, 1999, pp. 131-32.
} 
limit. During just the last twelve years of Elizabeth's reign the war cost $£ 3,500,000$, almost entirely absorbing the Crown's $£ 300,000$ annual income. ${ }^{73}$

Cecil's best documented expression of his belief in alchemy occurred in the context of this financial desperation. Hearing that John Dee's former assistant Edward Kelleynow living in Bohemia-had succeeded in alchemical transmutation Cecil began a long campaign to convince the alchemist to return to England to aid the Crown's finances. Between 1587 and 1593, Cecil sent numerous letters, spies and envoys to Bohemia, entreating Kelley to return and perform his art for the benefit of the Queen. Cecil genuinely thought that Kelley could be the solution to England's financial woes.

Many popular misconceptions and dubious assertions about Edward Kelley originated in two contrasting early modern works: Elias Ashmole's Theatrum Chemicum Britannicum (1652) and John Strype's Annals of the Reformation (1709). The appendix of Ashmole's compendium of alchemical texts contains an account of Dee and Kelley's travels in Europe. Relating their discovery of "a very large quantity of the Elixir in some part of the Ruines of Glastenbury-Abbey", Ashmole's account was concerned with tales of Kelley's alchemical transmutations, rather than his communication with Cecil. ${ }^{74}$ Strype, on the other hand, concluded that Cecil wanted Kelley more as a political informant than an alchemist, a notion accepted by Cecil's biographer Edward Nares. ${ }^{75}$

Charles Mackay included an account of Edward Kelley in his popular but poorly researched Memoirs of Extraordinary Popular Delusions and the Madness of Crowds (1856). ${ }^{76}$ In an attempt to chronicle popular folly, Mackay summarised many of the myths surrounding Dee and Kelley. Typical of most nineteenth century attitudes towards alchemists, Mackay repeated many uncorroborated assertions about Kelley. He expanded and elaborated upon

\footnotetext{
${ }^{73}$ C. E. Challis, The Tudor Coinage, Manchester, 1978, pp. 253-54.

${ }^{74}$ Elias Ashmole, Theatrum Chemicum Britannicum, London, 1652, p. 481-83.

${ }^{75}$ Strype, Annals of the Reformation: Vol. 3, pp. 132-33; Nares, Memiors of the Life and Administration: Vol. 3, p. 340.

${ }^{76}$ Charles Mackay, Memoirs of Extraordinary Popular Delusions and the Madness of Crowds, London, 1856.
} 
the accounts of Elias Ashmole and Strype in order to present him as "more of an impostor than an enthusiast", who was imprisoned almost as soon as he entered Prague, only to die trying to escape. ${ }^{77}$ Mackay went out of his way to portray Kelley in an unflattering light: Strype's description of him as a "gentleman" and "famous English chymist" became "deficient in rectitude and right feeling...a vagabond"; Ashmole's description of Kelley's famous chemical demonstrations became "low cunning and quackery". ${ }^{78}$ This unscholarly account coloured later historians' accounts, including Kelley's entry in the Dictionary of National Biography (1891), which repeated many of the same errors, using Mackay's work as a reference. $^{79}$

More recent scholarship has noted Cecil's credulity in Kelley's alchemical promises. In the first modern biography of John Dee, Charlotte Fell Smith observed that Cecil played the key role in the attempts to convince Kelley to return to England and asked "what is to be said of a staid and sober minister like Burleigh being ready to credit the truth of Kelley's exploits?" ${ }^{80}$ Ralph Sargent dismissed Cecil's interest in alchemy as a 'weakness' noting that when Edward Dyer returned to England bearing news of Kelley and Dee's alchemical success "in Burghley and Elizabeth he found attentive listeners. Alchemy, it happened, was a weakness of both of them". ${ }^{81}$ To both Fell Smith and Sargent, a belief in alchemical transmutation was a flaw incompatible with their understanding of Cecil.

In his study of the intellectual environment surrounding Emperor Rudolf II, R. J. W. Evans provided much needed details of Kelley's career at the Imperial Court. By examining Czech documents, Evans demonstrated the important position that Kelley held in the Court, whilst dispelling a number of myths about his eventual demise. Evans' recognised that the traditional view of Kelley as "a thorough charlatan enjoying at most

\footnotetext{
77 Ibid. p. 154.

${ }^{78}$ Mackay, Memoirs of Extraordinary Popular Delusions, pp. 153, 192-193; Srype, Annals Vol 3, pp. 133, 135; Ashmole, Theatrum Chemicum pp. 481-84.

79 Thomas Seccombe, 'Kelley, Edward (1555-1595)', in Leslie Stephen (ed.), Dictionary of National Biography, London, 1891

${ }^{80}$ Charlotte Fell Smith, John Dee 1527 to 1608, London, 1909, p. 203.

${ }^{81}$ Ralph Sargent, The Life and Lyrics of Sir Edward Dyer, Oxford, 1935, 2nd Edition, 1968, p. 105.
} 
some sadly abused talents" was an exaggerated and incomplete assessment. ${ }^{82}$ Rather Kelley demonstrated a "thorough familiarity with the technical procedures of occultism". 83 However, while Evans noted Cecil's interest in Kelley, a thorough examination was not within the bounds of his study. ${ }^{84}$

The most thorough recent account of Kelley's alchemical activities is Michael Wilding's article 'A Biography of Edward Kelley, the English Alchemist and Associate of Dr. John Dee' (2007). ${ }^{85}$ Wilding utilised the majority of the available English language manuscript evidence, along with the Czech evidence uncovered by Evans, to present a largely accurate narrative of Kelley's time in the Holy Roman Empire. Wilding dispelled some of the plethora of myths and misinterpretations that have surrounded Kelley since his death. However, Wilding offered almost no analysis of Kelley's importance and only provided a narrative of his travels and correspondence. When Wilding attempted to explain Cecil's interest in Kelley he fell back to Strype's unlikely explanation of Kelley as an informant. ${ }^{86}$

Susan Bassnett has recently made a compelling argument for Edward Kelley being the step-father of the prominent Latin poet, Elizabeth Weston. Bassnett argued that previous historians have had a "somewhat xenophobic interpretation that sees Rudolph and the powerful Rozemberk [Rosenburg] as Kelley's gulls", while understating English interest in the alchemist. ${ }^{87}$ She recognised that "Burghley at least took Kelley's scientific claims seriously". ${ }^{88}$ This, however, was the limit of her analysis of Kelley's relationship with the English Court.

Glyn Parry's upcoming biography of John Dee, The Arch-Conjuror of England: John Dee and Magic at the Courts of Renaissance Europe (forthcoming 2010) puts the episode into the

82 R. J. W. Evans, Rudolf II, pp. 225-26.

83 Ibid.

84 Ibid. p. 228.

${ }^{85}$ Michael Wilding, 'A Biography of Edward Kelly, the English Alchemist and Associate of Dr. John Dee', in Stanton J. Linden, Mystical Metal of Gold: Essays on Alchemy and Renaissance Culture, New York, 2007, pp. 35-89. 86 Wilding, 'A Biography of Edward Kelly', pp. 61-62.

${ }^{87}$ Susan Bassnett, 'Absent Presences: Edward Kelley's Family in the Writing of John Dee' in Stephen Clucas (ed.), John Dee: Interdisciplinary Studies in English Renaissance Thought, Dordrecht, 2006, p. 287.

${ }^{88}$ Ibid., p. 288. 
context of Dee's failed English Court career. ${ }^{89}$ By considering Dee's motivations in light of previously unexamined evidence, Parry reassesses Dee's role in the episode. However, his focus is on Dee, rather than Cecil's relationship with Kelley.

In contrast to previous historians, we can now reinterpret Cecil's interactions with Kelley within the context of his established alchemical interests. In this context Cecil's efforts to either lure Kelley back to England or obtain some of the alchemist's elixir can be seen as genuine-the efforts of someone convinced of the reality of alchemical transmutation (if not the trustworthiness of individual alchemists) - and expecting to secure England's finances by alchemical means.

Kelley probably first became known to Cecil as a 'scryer' or medium for John Dee's angelic magic in $1582 . .^{90}$ By September 1583, Dee's 'spiritual conferences' with various angels, communicated through Kelley, convinced him of the need to leave England before the coming apocalypse. ${ }^{91}$ Leaving England with Albrecht Laski, the Palatine of Sieradz in Poland, Dee and Kelley eventually after many vicissitudes settled in Bohemia as servants of the Earl of Rosenberg. ${ }^{92}$

Dee's records of his angelic conversations reveal that they had brought alchemical books and a 'red powder' with them from England, but that Kelley initially failed in his attempts at transmutation. ${ }^{93}$ It was not until October 1586 that Dee began to make cryptic references to alchemical success. ${ }^{94}$ While at first Kelley had been merely an assistant, he began to overshadow Dee. Likely the English Court's obsession with Kelley's abilities originated with the English merchants Edward and Francis Garland. When, on 19 December 1586, Kelley “made a public demonstration of the philosopher's stone" for the

\footnotetext{
89 Parry, The Arch-Conjuror of England.

${ }^{90}$ Ibid.

${ }^{91}$ Ibid.

92 Ibid.

${ }^{93}$ John Dee, Meric Casaubon (ed.), A True \& Faithful Relation of What Passed for Many Yeers Between Dr. John Dee and Some Spirits, London, 1659, second pagination, p. 12.

94 Ibid, pp. 444-47.
} 
brothers, he must have known the news would get back to England. ${ }^{95}$ The angels, through Kelley, told Dee that Francis Garland was “an espy upon us from the Lord Treasurer of England". ${ }^{96}$ Whilst there is no further evidence of this, Francis was certainly communicating information to Francis Walsingham, the head of the Elizabethan intelligence network. $^{97}$

By late November 1587 Cecil and the Queen, through the courtier Edward Dyer, began their efforts to convince Kelley to return home to perform alchemy for the English Crown. ${ }^{98}$ A member of the Earl of Leicester's retinue, Dyer studied alchemy and metallurgy with Dee after his arrival at Court in 1566. ${ }^{99}$ The high cost of Court attendance, along with the notorious expense of alchemical experimentation, perhaps explain why Dyer remained mired in debt throughout his life. ${ }^{100}$ When, in July 1580, Dyer travelled to Bohemia on Cecil's behalf, he made it clear that the English Court's interests lay in Kelley's alchemical abilities. The Court's preference for Kelley was a blatant sub to Dee; he recorded in his diary that "Dier did injure me unkindly". ${ }^{101}$ With the Spanish Armada anchored in Calais, the English government wanted Kelley's gold making abilities to fund their defence against the coming invasion. Although Dyer was unable to convince Kelley to return, Dee must have realised that his chances of English favour relied on his former assistant. Attaching himself to Kelley's coattails, Dee wrote to Queen Elizabeth in November 1588, congratulating her on the English victory over the Armada and accepting her invitation "calling me, Mr Kelley, and our families home, into your British earthly paradise". ${ }^{102}$

\footnotetext{
95 John Dee quoted in Parry, The Arch-Conjuror of England.

${ }_{96}$ Dee, Casaubon (ed.), A True \& Faithful Relation, second pagination p. 12.

${ }_{97}$ John Dee to Francis Walsingham, 17 June 1587, TNA, SP 15/30/30.

98 Parry, The Arch-Conjuror of England.

${ }^{99}$ Sargent, The Life and Lyrics, p. 40

100 Ibid. pp. 150-55.

101 Dee, The Private Diary, p. 28.

102 John Dee to Queen Elizabeth, November 1588, reproduced in Henry Ellis (ed.), Original Letters of Eminent

Literary Men of the $16^{\text {th }}, 17^{\text {th }}$ and $18^{\text {th }}$ Centuries, London, 1843, pp. 45-46.
} 
By March 1589 Dee had left Bohemia for Saxony, hoping “to mete Mr. Edward Kelley at Stade, going also into England". ${ }^{103}$ However, Kelley showed no willingness to return to the "earthly paradise", leaving Dee to travel to England alone on 19 November. ${ }^{104}$ While Dee's reception was favourable — the Queen visited his house in December 1590_ without Kelley at his side his Court career stalled. ${ }^{105}$ Many of Dee's former patrons, such as Leicester and his brother the Earl of Warwick, had died, and an increasingly conservative Court, influenced by Archbishop John Whitgift, had little enthusiasm for occult philosophy.

Back in Bohemia, Kelley's alchemical process had attracted considerable attention. News of his alchemical success had reached Rudolf, who quickly abandoned his previous indifference to the alchemist. The Emperor knighted Kelley, granting him a patent to nobility and lands that Kelley claimed yielded $£ 1,500$ a year. ${ }^{106}$ Moreover, Kelley moved to Prague, where he received a prestigious position as manager of the Emperor's alchemical works. ${ }^{107}$ Such was Kelley's new found status within the Holy Roman Empire that Rudolf appointed him to his Privy Council. Kelley also claimed to be "Chief Regent in and over all the lands and affayres of the Prynce Rosenberg" who exercised an authority in Bohemia that rivalled the Emperor himself. ${ }^{108}$

In June 1589, a dispute between Kelley and an English agent in Prague may have prejudiced some at the Elizabethan Court's belief in Kelley's alchemy. Kelley charged the former Jesuit Dr. Francis Parkins with being the "right hande or cheeffe man to the kinge of Spayn and the Pope in all their trencherious enterprises against Englande" intending "the murtheringe of oure Queene". ${ }^{109}$ However, it seems that this may have been cover for

\footnotetext{
103 Dee, The Private Diary, p. 32.

104 Ibid.

105 Ibid.

106 Edward Kelley to Cecil, 24 July 1590, TNA, SP 81/6 f.57r.

107 Ibid.

108 Ibid.

${ }^{109}$ Edward Kelley, June 1589, BL, Harley MS 6994 f.182r.
} 
Parkin's role as an English agent. An anonymous account states that, having saved Cecil's grandson from danger in Rome, the Lord Treasurer had "procured [Parkins] to be employed sometime abroad as ye Q[ueen's] agent" and that he may well have involved himself in some plot in order to "cozen ye Preestes and Jesuites". ${ }^{110}$ Nevertheless the accusation certainly troubled Parkins, who wrote to Walsingham describing Kelley as an "evell meaninge man as common fame reportyth". ${ }^{111}$ Walsingham in turn replied to his "loving friend" that without clear evidence from Kelley, he did not doubt that Parkins was "armed with the innocence of a clear conscience". ${ }^{112}$ Such attacks on English informers doubtless did not endear Kelley with Walsingham and his network of agents.

As Walsingham's health deteriorated in the two years leading up to his death in April 1590, Cecil increasingly took control over European intelligence gathering. ${ }^{113}$ This coincided with rising English interest in Kelley. As the informal head of the European network of English informants, Cecil monitored Kelley's meteoric rise, seeking proof of his ennoblement by obtaining a copy of his knighthood. ${ }^{114}$ An unknown messenger delivered to Cecil "a boxe with the ower and [p] owder of the silver mynes" on 9 March $1590 .{ }^{115}$ Whether this was a sample of Kelley's supposedly alchemical powder, or an example of the more practical benefits of his alchemical skills is unclear, but it clearly piqued Cecil's interest. He amended his letter to the Italian financier and English informant Sir Horatio Palavicino, written the day before, adding that he would also like to know "how Sir Edward Kellyes profesion may be credited". ${ }^{116}$ By 15 August Cecil had received a reply by way of a letter forwarded from another Italian informant, Francesco Pucci. A former collaborator with Dee and Kelley in angelic scrying, Pucci described the alchemist as "inconstant in matters of religion, long in promises but short in deeds; vain and intolerably haughty;

\footnotetext{
110 Ibid.

111 Christopher Parkins to Francis Walsingham, 12 March 1590, TNA, SP 12/231/17.

112 Walsingham to Parkins, 16 March 1590, BL, Harley MS 6994 f.209r.

113 Read, Lord Burghley, p. 464.

114 A Copy of Edward Kelley's Patent of Ennoblement, 23 February 1590, BL, Lansdowne Vol. 66 No. 60.

115 Anon. to Cecil, 9 March 1590, as quoted in Sargent, The Life and Lyrics, p. 106.

${ }^{116}$ Cecil to Horatio Palavicino, 8 March 1590, TNA, SP 81/6 f.9v.
} 
entirely self centred". ${ }^{117}$ Cecil likely received many more, now lost, reports from his overseas operatives on both the legitimacy of Kelley's alchemical claims, and on the prospects of convincing him to return to England.

Cecil also sent letters directly to Kelley, in which he entreated the alchemist to return to England and serve his sovereign monarch. Kelley replied to Cecil on 24 July 1590, that while

we accord fully in matter and manner though in circumstances somwhat differ, for yt seemeth you desire the same thinge...the thinges looked for at my hands deserve farther grace and assurance reall than any way or where yet appereth ${ }^{118}$

Kelley's writing was remarkably self assured; the mark of a man who knew his services were in demand. He stated that he would be happy to serve his Queen and country if granted the appropriate honours and maintenance, if not his "remayning abrode shall be her fault". ${ }^{119}$ Kelley knew that Crown finances were inadequate to support the cost of war with Spain, and guessed that if he played his cards right he might extract massive concessions from the alchemically credulous Lord Treasurer.

Cecil's reply, preserved in draft form in the Lansdowne Papers, demonstrates that he was neither so gullible as to ignore the swirling rumours about Kelley, nor willing to make any firm promises until he received direct proof of Kelley's abilities. After complementing Kelley's “wisdom well mixed with a naturall dutyfull regard to your contraye and soverayn", Cecil confronted the alchemist with the accusations made about him in England. ${ }^{120}$ Amongst the allegations was that Kelley had either been converted to Catholicism, or was in league with England's enemies. However, Cecil's primary concern was that Kelley would prove himself "an impostor [and a deceiver-deleted], with your sophistication, as many hertofor both here and in other contres have bene proved; and that

\footnotetext{
${ }_{117}$ Francesco Pucci to Horatio Palavincino, 25 August 1590, TNA, SP 81/6 f.70r.

118 Kelley to Cecil, 24 July 1590, TNA, SP 81/ 6 f.47r.

${ }^{119}$ Ibid.

${ }^{120}$ Cecil to Kelley, 1 June 1590, Lansdowne Vol. 103 no. 73.
} 
you wold fear to be proved such one here, because of danger of severe punishment". ${ }^{121}$ Cecil's experiences with de Lannoy twenty years earlier had taught him to be cautious of promises of outright alchemical riches.

Despite his concerns, Cecil reassured Kelley that the Queen still very much desired the benefit of his alchemical skills. The Lord Treasurer of England, in the same sycophantic terms he usually received from those seeking patronage, wrote that

such is my creditt in Mr Dyar, such is my allowance of your loyall profession, such opinion I do firmly conceave of your wisdom and lerning expressed in your 1[ett]res, such also is my perswasion of your abillite to perform that which Mr Dyar hath reported, by reason of that estimation honor and credit I see that you have gotten by your behaviour ${ }^{122}$

Cecil assured Kelley that his only complaint was that the alchemist delayed coming home to serve his monarch. He mentioned that the Queen had personally written to Kelley, a remarkable indication of her personal interest in the possibility of alchemical profits. After urging Kelley not to delay, Cecil thanked him for his gift of a "mountayn, or rock...which I will place in my house wher I do bestow other rare thyngs of workmanshipp", which Wilding speculates may have been a German Handstein "a model of a mountain made up of assays of ore, stone and crystal". ${ }^{123}$ If so it was a substantial present: Handstein were highly valued, princely gifts. ${ }^{124}$ Cecil also requested "some small recept from you, that might comfort my spyritts in myn age...for I esteme helth above welth", further illustrating Cecil belief in the efficacy of alchemical medicines. ${ }^{125}$

Kelley's reply strongly denied all of the accusations made against him by "these Bablers", especially reports of him being an impostor. ${ }^{126}$ Kelley directly accused anyone spreading the rumours of being "a knave and that he lyeth in his throte, and will mayntain yt with my swoord upon his Carkas wheresoever I can or shall fynde yt". ${ }^{127}$ Returning to

\footnotetext{
121 Ibid.

122 Ibid.

${ }^{123}$ Ibid.; Wilding, 'A Biography of Edward Kelly', p. 27.

124 Gordon Campbell, Renaissance Art and Architecture, Oxford, 2004, p. 126.

125 Cecil to Kelley, Lansdowne Vol. 103 no. 73.

126 Kelley to Cecil, 24 July 1590, TNA, SP 81/6 f.56r.

127 Ibid. f. $57 \mathrm{v}$.
} 
Cecil and the Queen's demands that he return to England, he argued that as at his ennoblement he had been sworn to promote virtue and chivalry, he could not in good conscience leave his imperial honours. That was, unless

yt may please my most gracious Soverayne and Country to redres the Injuries done against me heretofore. And to call me home to the like honor. Assuring me of so much Lands of inheritance by yere to serve her, as I shall leave behynde me in Bohemia for her: Then will I declare my self openly ${ }^{128}$

In his next letter of 10 August 1590, Kelley declared his terms even more openly; unless Cecil and the Queen promised him equivalent wealth and lands in England, "I am not so madd to runne awaye from my present honor and lands". ${ }^{129}$ Noting that as "your L[ordship] maketh mutch of the tryfle i sent you [presumably the Handstein]: I will shortly present you with som better thinge", Kelley then took his leave of the Lord Treasurer. ${ }^{130}$

If Kelley's abruptness offended Cecil, he got no hint of this in the Lord Treasurer's replies. A 31 October 1590 letter to Cecil, expressed Kelley's pleasure that Cecil and the Queen had been well contented with his letters. ${ }^{131}$ However, Kelley remained adamant that the Queen and Cecil's vague promises were insufficient and that he would prefer to "honorably serve and satisfy her gracious highnes abrode, being settled and contented allready with sufficient reputation and lyvinge". ${ }^{132}$ If Cecil was discouraged by Kelley's obstinacy, Edward Dyer's enthusiastic reports retained his interest. By October 1590 Dyer had once again travelled to Bohemia to convince Kelley to return on Cecil's behalf. With increasing hostility towards the English in Prague, Dyer found that Kelley declined his efforts to obtain "some medecyne to have satisfyed her majesty by her own blisfull sight", supposedly because Kelley feared raising suspicions about his loyalty in the notoriously unstable Emperor. ${ }^{133}$

\footnotetext{
${ }^{128}$ Ibid. ff. 57r-58v.

${ }^{129}$ Kelley to Cecil, 10 August 1590, TNA, SP 81/6 f.66r.

130 Ibid.

${ }^{131}$ Kelley to Cecil, 31 October 1590, TNA, SP 81/6 f.79r.

132 Ibid.

${ }^{133}$ Edward Dyer to Cecil, 31 October 1590, TNA, SP 82/3 f.134r.
} 
Dyer remained in Prague through the winter of 1590-91 and worked alongside Kelley in an attempt to learn his alchemical secrets. ${ }^{134}$ If Kelley could not be convinced to return, surely he would be willing to teach Dyer his process, thereby allowing England the benefits of alchemical transmutation. Kelley later recalled their collaboration:

what delight we tooke together, when from the Mettall simply calcined into powder after the vsuall manner, distilling the Liquor so prepared with the same we converted appropriat bodies (as our Astronomie inferious teacheth) into Mercury the first matter ${ }^{135}$

If Cecil had wanted someone to learn the secret from Kelley for England's benefit, Dyer, with his alchemical experience gained under Dee, would have been the obvious choice.

On 1 May 1591 Cecil once again wrote to Kelley, this time stressing the medical potential of Kelley's alchemical skills. Cecil requested that Kelley send him "some thing of your operation to strengthen me afore the next wynter against myne old ennemye the goute". ${ }^{136}$ Wilding argued that this may have been a coded message; that a prominent political figure would be unlikely to reveal a disabling illness via easily intercepted letter. ${ }^{137}$ Interpreting Cecil's complaints as referring to the political situation in the Holy Roman Empire, Wilding proceeds to speculate about the possibility of Kelley acting as a spy in the Imperial Court. ${ }^{138}$ This interpretation is unconvincing. Most of Europe knew that Cecil suffered from gout—endemic throughout the upper strata of European society-as demonstrated by the offers of cures that Cecil received from throughout Europe.

If Cecil coded any sort of message within the letter, it seems more likely that he was attempting to disguise an appeal for alchemical gold as a less politically sensitive plea for alchemical medicine. Without the trustworthy Dyer as a courier, the possibility of interception would have concerned Cecil. Cecil certainly skirted around any direct mention of transmutation, writing in more general terms about "the satisfaction of us all here that

\footnotetext{
134 Sargent, The Life and Lyrics, p. 112.

135 Kelley to Dyer, quoted in Sargent, p. 112.

136 Cecil to Kelley, May 1591, BL, Lansdowne Vol. 103, No. 72, (Lansdowne Vol. 104, No. 56 is identical without a concluding sentence begging Kelley to use his gift for the benefit of his own country rather than for strangers).

${ }^{137}$ Wilding, ‘A Biography of Edward Kelly', pp. 61-62.

138 Ibid.
} 
love and honor vertue and knolledge". ${ }^{139}$ Perhaps Cecil knew that Dyer's presence was raising doubts in Prague about Kelley's loyalty to the Emperor. Regardless, Cecil's previous consultation with Paracelsian physicians such as Russwurin suggests his medical appeal was not entirely disingenuous, for whilst the

moste dyrect cause [of his illness] is oppression with affaires, and lacke of liberty, against the which no medicinall receipt can serve... yett I wilbe glad to make much of any that you shall send me, with your assurance that it shall do me no harme ${ }^{140}$

That the astute Cecil would trust the tinctures of a man so often derided by historians as the archetypal alchemical charlatan, is indicative of both his belief in alchemical medicine and the reputation Kelley enjoyed in England.

A letter to Dyer, drafted on 12 May in Cecil's own spindly hand, provides the most compelling evidence of Cecil's genuine belief in Edward Kelley's alchemical abilities. Sent by secure courier to his long time acquaintance, Cecil did not have to be concerned about offending the alchemist's ego, and could give a truer account of his actual opinion on the matter. The authenticity of Cecil's desire for the rogue alchemist to return to England is evident. Convinced by Dyer's "stedfast first opinion of Sir Edward Kelly, namely as you write for that worthy truth in him at that highest poynt that hath bene before by you reported", Cecil instructed Dyer to convince Kelley to "retorn to his natyve contry, to honor hir majesty as a loyal natural subject with the fruits of such great knolledg as God hath gyven hym". ${ }^{141}$ He once again emphasised that the "Quene is, of hir very divine nature most redy to reward yea to honor knolledge in any person", which would equal anything given to Kelley by foreign princes. ${ }^{142}$

Cecil maintained that those in England who wrote against Kelley would either be persuaded by a demonstration of Kelley's transmutation, or were enemies of the Crown, attempting to keep the alchemical benefits out of the Queen's hands. However, Cecil's

${ }^{139}$ Cecil to Kelley, Lansdowne Vol.103, No. 72.

140 Ibid.

${ }^{141}$ Cecil to Edward Dyer, 12 May 1591, BL, Cotton Titus B. II, no. 110.

142 Ibid. 
patience was clearly wearing thin. He warned Dyer that if Kelley would not return, he would, "contrary to my present good opinion of hym", be forced to think him either a fake or a traitor. ${ }^{143}$ Cecil did, however, propose another possibility: if Kelley could not come home then surely he could

send to hir majesty, for a token, some such portion, as might to hir a some reasonable to defray hir charges for hir navy, which even now we are preparing to the seas to withstand a strong Navy of Spayn, discovereyed uppon the cost betwin britany and Cornwale within these ii days ${ }^{144}$

This letter reveals the true magnitude of Cecil's hopes for Kelley. If a mere 'token' of the philosopher's stone could defray the costs of England's navy, the extent of Cecil's final expectations must have been truly massive. Cecil may have also had personal hopes for Kelley's abilities. The Queen was in the midst of a ten day visit to his Hertfordshire mansion, Theobolds — at a cost to him of $£^{9} 998.13$ s.4d. - which Cecil "wold be contented might have bene tripled, if I had but one corn of Sir Edw Kellyes powder". ${ }^{145}$

Cecil's caution in communicating with Kelley proved well founded, as tension in Prague had finally come to a head. Even while drafting his letter to Dyer, Cecil received reports that Kelley had fled from Prague, although the circumstances were unclear. ${ }^{146}$ A steady trickle of information regarding the alchemist's troubles, often ambiguous about Kelley's circumstances or whereabouts, began to reach Cecil. Even the well informed Palavicino could not determine whether Kelley was attempting to return to England at Dyer's instigation, or merely escaping from debt. ${ }^{147}$ Edward Wotton forwarded Cecil a 15 May letter he had received from an English merchant recently returned from Prague, almost certainly his half brother Henry Wotton, detailing the swirling rumours surrounding

\footnotetext{
143 Ibid.

144 Ibid.

145 Ibid; A. G. R. Smith, 'Lord Burghley and his Household Biographers: John Clapham and Sir Michael

Hickes', in Croft (ed.), Patronage, Culture and Power, p. 262.

${ }^{146}$ Cecil to Dyer, Cotton Titus B. II, no. 110.

${ }^{147}$ Horatio Palavicino to Cecil, 6 May 1591, TNA, SP 81/ 6 f.205r.
} 
Kelley's demise. ${ }^{148}$ Wotton reported that on 30 April the Emperor had ordered the town guard to apprehend Kelley, only to find that the alchemist had fled. Rudolf, furious at Kelley's escape, "cursed in the Dutch manner", and threatening his patron the Earl of Rosenburg "that if [Kelley] came unto him, he shoold deliver him upon his alleageance to the Crowne of Bohemia". ${ }^{149}$ Rosenburg's allegiance was not tested, as the authorities arrested Kelley a few days later in the nearby town of Sobeslav. ${ }^{150}$ Kelley's star had waned dramatically to incur such wrath.

Wotton assumed that Kelley's crime had been "waighty and hayneus...bicause it is contrary to the Emporers humor and course of the house of Austria to proceed in Criminal matters either so violently or so generally". ${ }^{151}$ He had heard several reasons for Kelley's demise, although he dismissed rumours of debt as the cause, as Kelley owed nothing to the Emperor himself. Some thought that Kelley had insulted either the Emperor or one of the prominent families of Bohemia; others had heard that Rudolf had become convinced that a medicine Kelley made for his heart was in fact a poison. Still other reports detailed either a commercial dispute with an Italian named Scotto, or that Kelley had been in league with a recently executed Venetian alchemist. Wotton told his half brother that

Till certainer advise i wil hould this opinion that Sir Edward Kelley hath at some tyme or other vaunted at his table or in his conversation with others, that the queen hath sent for him (as he is a man who takes as I heer a pleasure in speaking that princes desire him). Howsoever it be, it is likely in this cause much to hurt him, the Emperor being assurdly informed that he is sent for ${ }^{152}$

The notoriously unstable Rudolfs jealousy, augmented by the anti-English whisperings of Court Catholics, would certainly have been enough to warrant Kelley's forcible detainment.

Wotton thought Kelley would avoid execution, as the "Erle of Rosenburg wil ernestly interpose himself and in Bohemia it is a rule that his majetie dare doo nothing

\footnotetext{
${ }^{148}$ Henry Wotton to Edward Wotton, 15 may 1591, BL, Lansdowne Vol. 68, no. 85.

149 Ibid.

${ }^{150}$ Ibid.

151 Ibid.

152 Ibid.
} 
without the Erls consent". ${ }^{153}$ On the other hand, Sir Robert Sidney, governor of Flushing, wrote to Cecil, that hearing of the recent execution of an alchemist in Munich "it is thought there [Kelley] w[i]l run the same race that the other did". ${ }^{154}$ The two stories became conflated. Matthew Greensmith reported to Cecil on 5 June 1591, that on

$29^{\text {th }}$ Aprill last ther hanged att Prage an Inglyshman somtyme of grett reputatyon by the emporer and a macker of gold, accused \& comdemnd for dyvers matters of trechory so that I cane nott judge itt no body butt Kelley ${ }^{155}$

Whilst such reports proved entirely unfounded, the safety of both Kelley and Dyer remained a prime concern of Cecil's intelligence network.

After hearing of Kelley's imprisonment, Cecil dispatched Thomas Webbe, a reliable minor courtier, on 11 June 1591 to obtain more accurate information about the situation. ${ }^{156}$ Cecil instructed Webbe to discover whether Dyer had been arrested, and if so use letters from the Queen to Emperor Rudolf, the Elector of Saxony and the Landgrave of Hesse, to secure his release. Webbe was then to "inquire dilligently, wher Sir Edwd Kelly is arrested, and for what cause". ${ }^{157}$ Cecil emphasised English concern over exactly why Kelley had been arrested. It would be one thing if Kelley had been detained for his own debts or deceptions; there would be entirely different implications if his

intention was to have secretly come into England, and her[e] to have served hir majesty, with his science, and that [he had been arrested] by malliscye of the popes nuncio or ye Sp[anish] ambassador or otherwise by ye Emperor, as unwillyng to have hir Majesty benefited by hym with his science ${ }^{158}$

On 26 June 1591, Webbe wrote to Cecil before reaching Prague, "being bound to certefye unto your L[ord] as mutch as I could perticularlye learne". ${ }^{159}$ Kelley remained imprisoned, and all of his lands and goods had been seized by the Emperor, although the Earl of Rosenburg had ensured Kelley's better treatment, the alchemist being now "only

\footnotetext{
153 Ibid.

154 Robert Sidney to Cecil, 22 May 1591, TNA, SP 84/42 f.68r.

155 Matthew Greensmith to Cecil, 5 June 1591, TNA, SP 81/7 f.28r.

${ }^{156}$ Cecil to Thomas Webbe, 11 June 1591, BL, Lansdowne Vol. 103, No. 67.

157 Ibid.

158 Ibid.

159 Thomas Webbe to Cecil, 26 June 1591, BL, Lansdowne Vol. 68, No. 93.
} 
depryved of his libertye and frends". ${ }^{160}$ Webbe also reported that whilst Dyer had initially been put under house arrest, his treatment had supposedly improved. It is likely that Webbe had obtained more politically sensitive information, as he sent the letter via one of Kelley's servants, who could, Webbe assured Cecil, provide more details on events. ${ }^{161}$

An unsigned note, catalogued in Cecil's records as "some necessary queries relating to the state of Sir Edward Kelley", clearly written shortly after Kelley's arrest, gives further evidence as to the nature of Cecil's concerns. ${ }^{162}$ Although the author recognised that the "cheife point upon which all those matters do depend is whether the transmutation so famouslye spoken of be trewe or no", it was also important to ascertain the alchemist's intentions if his escape had succeeded: "whether his journey were intended for England or otherwise for his owne private purpose". ${ }^{163}$ The author assumed that if Kelley had been attempting to flee to England, then Cecil would still be interested in his services, and either he or Edward Dyer would have to arrange the alchemist's release.

Unable to procure Kelley's return to England, Cecil's informants went looking for others who may have obtained the alchemist's secret. It was noticed that an Englishman, Thomas Page, had recently returned from Prague, and had brought alchemical equipment back with him. Cecil demanded to know if Kelley had divulged his secret to Page. Page assured the Lord Treasurer that he had not brought back philosophical mercury, a preparative to the philosopher's stone, but merely "mercury the lyke wherof every shop doth afford". ${ }^{164}$ As proof he sent a small sample to Cecil for examination. Page knew of Cecil's hopes of alchemical success, and assured him that if "I had any lyttle quantetye of it wherewith to present her majesty y[our] Lordship should most wyllingly have had the

\footnotetext{
160 Ibid.

161 Ibid.

162 Anon. to Cecil, undated, BL, Lansdowne Vol. 68, no. 110.

163 Ibid.

164 Thomas Page to Cecil, 3 July 1591, TNA, SP 12/239/76.
} 
honor of presenting us bothe". ${ }^{165}$ Like many before him, Page knew that alchemical knowledge would have strengthened his chances of patronage from Cecil and the Queen.

The mercury samples did not placate the suspicious Lord Treasurer; he demanded that Page clarify exactly what he had been doing in Europe and what business he had with Kelley. Whilst Page's reply is undated and incorrectly catalogued in the Public Records Office under 2 July 1576, its contents clearly reveal that it was written some time in $1591 .{ }^{166}$ Page claimed that, having spent a large portion of his estate in a court case, he had travelled to Prague to convince Kelley "to be a favourer of the attempt of a true dyscoverye for China or the northe and east parte therof otherwyse called Cat[h]ayes". ${ }^{167}$ There is no other record of any attempt to involve Kelley in the discovery of the mythical north-west passage, which took on alchemical connotations during the Frobisher voyages, as detailed in Chapter four. Wilding suggested that "Perhaps the English hoped to draw on Kelly's new found wealth to invest in it". ${ }^{168}$ In any case, whilst Kelley greatly commended the exercise he was "perswaided the contrarye and it became to be suspended upon better delyberatyon as allso hys owne secret beysnes". ${ }^{169}$

Page had apparently been at Kelley's house in Prague when the alchemist had fled, and "amongst the tempest betoke me to my best escape that I could which I thank god I performed". ${ }^{170}$ Attempting to explain his rather hurried escape from Prague, just at the time of Kelley's arrest, Page claimed to have been travelling "wythe as much speed as i coulde" to comfort Kelley's mother in England. ${ }^{171}$ Whilst it is possible that Page had a closer relationship to Kelley and his family than has been realised by historians, the rather weak explanation creates suspicion about Page's real motives.

\footnotetext{
165 Ibid.

166 Thomas Page to Cecil, undated, TNA, SP 12/108/51.

167 Ibid.

168 Wilding, 'A Biography of Edward Kelly', p. 69.

169 Page to Cecil, SP 12/108/51.

170 Ibid.

171 Ibid.
} 
According to Page, Kelley had not intended to flee to England; rather he had been the victim of a conspiracy led by the Emperor's secretary, who had disputed Kelley's new found status. Page alleged that the secretary had failed in earlier attempts to trick Kelley into committing treason in order to learn from him the secret of the

phylosophers ston which he poseseth wythout question to the contrarye, wyth which knolledge if god should permyt he is able to perfect all the imperfect mettals in the worlde, which for my part I not at all marvell at but hold it as a naturell secret ${ }^{172}$

Page's view of Kelley "not delighting [in] the worlde but contemplatying hys divenity and inserchable workes" certainly conflicts with the alchemist's posthumous reputation. ${ }^{173}$

Kelley remained imprisoned until at least October $1593 .{ }^{174}$ In the interim, Robert Cecil took over much of the responsibility for intelligence operations from his aging father. Robert held more conservative philosophical beliefs than the elder Cecil, and remained sceptical about the possibility of alchemical transmutation. ${ }^{175}$ Indeed, the conservative elements within the English church with whom Robert Cecil identified found alchemy theologically suspicious. According to Francis Bacon, when Edward Dyer later described Kelley's transmutation to the Archbishop of Canterbury, he replied "You had take heed what you say Sir Edward Dyer for here is an infidel at the board". ${ }^{176}$

The information given to him by Kelley's former adversary, Christopher Parkins, further damaged Kelley's reputation with Robert Cecil. Parkins described those who believed in Kelley's alchemical promises as "simple" and told Robert Cecil that the Emperor's best men alleged "that he maketh trewe transmutation of metalls yet in such sort that he hath thearby losse and no comodityes". ${ }^{177}$ According to Parkins, Kelley had financed his lifestyle on credit by borrowing from Prague's Jewish community, who

\footnotetext{
172 Ibid.

173 Ibid.

${ }^{174}$ Wilding, 'A Biography of Edward Kelly', p. 73.

175 Patrick Collinson, The Elizabethan Puritan Movement, London, 1967, pp. 443-47.

${ }^{176}$ Francis Bacon, 'Apophthegms', in Basil Montague (ed.), The Works of Francis Bacon, London, 1823, p. 122.

177 Parkins to Robert Cecil, 20 July 1593, TNA, SP 81/7 ff.143r-144v.
} 
eventually complained to the Emperor when his debts remained unpaid. ${ }^{178}$ Kelley had fled Prague to avoid his angry creditors, it was suggested, rather than to evade a Court conspiracy or return to England to perform alchemy for the Crown. This and similar reports were unlikely to inspire confidence in the alchemically sceptical Robert Cecil.

During the last months of Kelley's imprisonment William Cecil made one last attempt to ascertain the alchemist's intentions. Cecil's clerk recorded a payment to William Hall to courier a message from the Lord Treasurer to Kelley on 28 August $1593 .{ }^{179}$ Unfortunately no record remains of the message's contents. Perhaps Kelley's response was not to his liking, as from this point onwards Cecil seems to have given up on the rogue alchemist. Whilst Robert Cecil's informants continued to pass on snippets of information detailing Kelley's fluctuating fortunes, English interest in his alchemical potential diminished. ${ }^{180}$

The exact circumstances of Kelley's demise are much debated. John Dee recorded Kelley's death on November 25 1595, whilst R.J.W. Evans cites Czech documents showing that Kelley was alive as late as 22 May 1597. ${ }^{181}$ The muddled accounts of Kelley's death describe his death from injuries suffered during an attempted prison escape, and are often confused with tales of the death of the fictitious Scottish alchemist, Alexander Seton. ${ }^{182}$ Jan Backlund suggests that these English accounts, uncorroborated by any Czech sources, may have been the result of deliberate misinformation, possibly from Kelley himself. ${ }^{183}$

Regardless, Cecil's expectations for the alchemical profits of Edward Kelley are nothing short of remarkable. He sincerely believed that Kelley's transmutation could be the key to saving England from Spanish aggression. This belief justified Cecil orchestrating

\footnotetext{
178 Ibid.

${ }^{179}$ Wilding, 'A Biography of Edward Kelly', p. 73.

180 Seth Cocks to Robert Cecil, 8 April 1595, TNA, SP 881/1 f.221.

${ }^{181}$ Halliwell (ed.), The Private Diary, p. 54; Evans, Rudolf II, p. 227.

182 See Rafal T. Prinke, 'The Twelfth Adept: Michael Sendivogius in Rudolphine Prague' in John Matthews (ed.), The Rosicrucian Enligbtenment Revisited, New York, 1999.

${ }^{183}$ Jan Backlund, 'In the Footsteps of Edward Kelley', p. 298.
} 
a number of attempts to convince Kelley to return, even during the hectic preparations for the coming Spanish Armada. Both Cecil and the Queen personally wrote to the alchemist, promising that if only he returned to England, he would be as well rewarded as anywhere else in Europe. When Rudolf imprisoned Kelley, Cecil feared that it was as a result of the Emperor, influenced by Catholic courtiers, becoming jealous of English influence over the alchemist. He assumed that Rudolf had detained Kelley in order to monopolise his abilities_-just as Cecil had done with de Lannoy. After the immediate threat of Spanish invasion faded, and Cecil delegated increasing responsibility to his son, English interest in Kelley faded. Whilst Kelley's activities would be monitored until his death, his abilities did not have the same significance to the new generation of English policy makers that it had to Cecil.

\section{Roloff Peterson}

In October 1593, less than two months after Cecil's last recorded letter to Kelley, the Queen received another proposal promising alchemical riches and longevity. Roloff Peterson, a merchant of Lubeck in the north of modern day Germany, wrote to Elizabeth offering the materials by which "any man but meanly skylfull in this arte, will worcke rare and most admyrable thinges". ${ }^{184}$ The Elizabethan Court's response to this offer further demonstrates Cecil's willingness to see alchemy as a solution to the Crown's financial problems.

The absence of Peterson and his alchemical materials from the existing scholarship illustrates the distorting effect of the false historical distinction between politics and alchemy. The mere mention of alchemy has dissuaded political historians from examining the episode. Alex Ryrie is the only historian to examine Peterson in The Sorcerer's Tale (2008), which confuses the issue entirely, stating that Peterson offered to use his own

${ }^{184}$ Roloff Peterson to Queen Elizabeth, 20 October 1593, TNA, SP 12/245/130. 
alchemical skills to create gold for the Queen. ${ }^{185}$ Aside from Ryrie, only G. B. Harrison, in his attempt to create "a record of those things most talked of during the years 1591-1594", gives any detail of Peterson's offer. ${ }^{186}$ Historians have overlooked an episode that not only reveals the Elizabethan attitude towards alchemy, but also England's relationship with the German principalities and city states.

Peterson's letter claimed that an Englishman named Clement Oldfield had come to lodge in his house, where he laboured "night and daye to the practize of the noble science (as he namede it) of true Alchemy". ${ }^{187}$ Coming within six months of perfecting his work, Oldfield fell ill, and on his deathbed revealed to Peterson the secrets of alchemy,

which consestethe in the knowledge of the grene and rede Lion from wheure a fyry nature is to be felt which the Philosophers do call prima materia: man and woman: Mercury and Sulphur in a homogenall nature ${ }^{188}$

Oldfield left Peterson three glass vessels containing the alchemical preparation of Sol, Luna, and Mercury, on the condition that they were offered to the Queen of England before all others. Claiming to be merely fulfilling Oldfield's dying wish, Peterson invited the Queen to send a man skilful in the alchemical arts to examine them. ${ }^{189}$

Robert Smith of Great Yarmouth delivered Peterson's letter to the Privy Council. Smith offered to assuage the Queen's doubts by bringing “both the body of the said Rowlyffe yf he lyve and thes glasses or bodes before hir highnes to be examined and proved as to hir wysdome shall seame best". ${ }^{190}$ So confident was Smith in the value of the materials, he believed that even if the Queen refused them, other European sovereigns would pay a huge sum for them. Smith, therefore, promised on the peril of his head to sell them and "bringe fortey thousand dollars $[£ 8,000$ contemporary $]$ in to hir majesties coferes for thes glasses or bodies without one peney of hir highnesses expense". ${ }^{191}$

\footnotetext{
185 Alec Ryrie, The Sorcerer's Tale, Oxford, 2008, p. 120.

186 G. B. Harrison, An Elizabethan Journal, Volume 1, London, 1928, pp. 277-8, 282, 287, 325.

187 Peterson to Elizabeth, SP 12/245/130.

188 Ibid.

189 Ibid.

${ }^{190}$ Robert Smith to Queen Elizabeth, 2 February 1594, TNA, SP 12/247/36.

191 Ibid.
} 
For the Queen and Cecil, Smith's offer was too good to resist. The Queen and her council instructed Smith to deliver their response to Peterson and to bring the three glass vessels back to England. The comprehensiveness of the instructions is striking. Smith was to retrieve from Peterson "all such writings, books and papers lefte in his house by the said Oldfield ... which in any way treate of the arte of Alchemy" along with any other chemicals he had that might aid in transmutation. ${ }^{192}$ Peterson was also required to reveal the details of his discussion with Oldfield

concearning the severall qualities of the said three materials, and whether he did esteeme them in thir kinds perfectly wrought and according to Arte howe longe he have travailled in the worke of eny of them, and yf he signified unto Peeterson any lacke or imperfection in any of the said materialls $^{193}$

The intention was clearly to make sure that, if the material would truly allow the transmutation of metals, they had everything necessary to perform the alchemical process. For the English Court the plan seemed foolproof. Even if the alchemical equipment proved to be worthless, they still had Smith's promise that he could sell it for a massive profit.

Peterson accompanied the materials to England, presumably expecting a reward from the notoriously parsimonious monarch. The Queen, who considered the alchemical equipment to have been "bequeathed to her majestie", was not eager to reimburse Peterson for the materials unless either their worth or resale value could be verified. ${ }^{194}$ In September 1594, after months of wrangling, a compromise was agreed upon. The Queen declared that in six months time either the glass bodies would be delivered unopened to the English merchant adventurers in Stade, for Peterson to collect, or Elizabeth would pay him ,500 $^{-}$ "if we shalbe pleased to detaine and keepe the thinges bequethed to our own use". ${ }^{195}$ This solution gave Smith enough time to find a buyer before the Queen would have to pay for

\footnotetext{
192 Anon. to Robert Smith, 20 February 1594, TNA, SP 12/247/72.

193 Ibid.

194 Ibid.

195 Declaration by Queen Elizabeth, 30 September 1594, TNA, SP 12/250/9.
} 
them. For it seems that by this stage, despite their previous interest, "hir majesty hath bene informed credibly, [that] they are of no vaulewe". ${ }^{196}$

The Court therefore decided to on-sell the materials to a gullible buyer. Robert Smith travelled to Germany, hoping to sell them to the Marquis of Brandenburg. A copy of Smith's instructions remains in the state papers. Whilst they are not signed, Cecil's later reference to Smith having received a "fewe articles for your better direction from me", implies that he probably composed the instructions. ${ }^{197}$ Upon reaching Berlin, Smith was to find a buyer as soon as possible, using as cover the pretence of searching for a German alchemical expert to assess the worth of Peterson's materials. If Smith could not conclude his negotiations within six months, he was to tell Peterson that the expert had fallen ill and that another two months would be required until a decision could be made. The entire venture had a distinct air of subterfuge, with Smith ordered to

in the whole course of your proceeding herin use all secrecy and discreation that yt maie not be conceived or imagined that the Queens majesty hath any furder intereste in the said materiales than as a princesse to whome they were once tendered for ther rarenesse and pretended pretiable qualitie ${ }^{198}$

Smith was explicitly instructed not to give the buyers any indication of interest from either the Queen or her Council; the matter was supposedly dealt with by a secretary to whom Smith was deputed. ${ }^{199}$ As no one sufficiently expert could be found within England, the materials were ostensibly being sold off to others with more relevant expertise.

On 15 March 1595, two days after Smith received his instructions, Sir Thomas Wilkes, clerk of the Privy Council and former ambassador to France, wrote to the London based governor of the Merchant Adventurers of Stade. He sent with his letter the three glass vessels of alchemical materials and asked for them to be forwarded to the company in Stade and kept safe until further orders. If Peterson should request the materials or the

${ }^{196}$ Cecil to Robert Smith, 4 October 1595, TNA, SP 12/254/4.

197 Ibid.

198 Anon. to Robert Smith, 13 March 1595, TNA, SP 12/251/57.

199 Ibid. 
$£, 500$ from the company, they were to repeat the story about the expert told by Smith. ${ }^{200}$ Five days before the deadline, on 15 April 1595, Peterson arrived at Stade, demanding either the glass vessels or the money. Thomas Ferrers, deputy governor of the Merchant adventurers, reassured Peterson that some orders would come with the next ships and wrote to Cecil seeking direction. ${ }^{201}$ The tone of his letter suggests that Ferrers had not yet received the glass bodies or his orders from Wilkes. Playing for time, and playing down Elizabeth's interest, Cecil replied that he had never heard of the Queen's promises to Peterson, and surmised the letter to be a forgery. ${ }^{202}$ Cecil therefore ordered Ferrers not to pay Peterson. Cecil feigned ignorance, as his later letters show that he had been intimately involved in arranging Smith's scheme.

On 28 April 1595, having finally received the materials and his instructions from Wilkes, Ferrers wrote to Peterson explaining that their German expert was ill and they needed more time. There are conflicting accounts of Peterson's response to the delays. Peterson claimed to have written to Ferrers a number of times, demanding an explanation. Frustrated, he eventually protested to the chief magistrate of Stade, demanding Ferrers pay him the $£, 500 .{ }^{203}$ Ferrers' counter protest of 28 February 1596 tells a very different story. According to Ferrers, Peterson had been content to wait for the Queen to obtain a suitable expert. ${ }^{204}$ On the last day of September, Peterson, supposedly and without any prior warning, demanded immediate payment of the $£, 500 .{ }^{205}$ Ferrers insisted that he had "never ben certefyed any waye of [Peterson's] mislike therof' and indignantly protested that "Peeterson hath faire forgotten himself, and remembers not the highe estate of the sacred person he dealeth with", 206

\footnotetext{
200 The Privy Council to Alderman Saltsonstall, 15 March 1595, TNA, SP 12/251/58.

201 Thomas Ferrers to Cecil, 15 April 1595, TNA, SP 12/251/10.

${ }^{202}$ Cecil to Thomas Ferrers, 18 April 1595 in R. A. Roberts (ed.) CMS, Vol. 5: 1591-1595, London, 1894, p. 177.

203 Protest of Roloff Peterson, 30 September 1595, SP 82/4 f.5r.

204 Protest of Thomas Ferrers, October 1595, TNA, SP 12/254/46.

205 Ibid.

206 Ibid.
} 
In the mean time, Cecil had lost patience with Robert Smith. After claiming some initial success in negotiations with the Marquis of Brandenburg (in which he had allegedly obtained "two writinges under his hand and seale concerning the materialls") Smith's efforts came to nothing. ${ }^{207}$ He soon fell out with his supposed broker, a Mr. Southwell, who had him arrested then deported. ${ }^{208}$ Cecil wrote to Smith admonishing him for having deceived the Queen. In a clear demonstration of his previous knowledge of the scheme he recalls that

I did frendly warne you before you departed of practising in these your idle conceites upon princes, and especially upon her majesty your soveraigne ${ }^{209}$

Arguing that "exposing them to a comon tender" when the materials were known to be of no value "in no wase wer honorable to be doone in hir majesties nam", Cecil suddenly developed doubts about the morality of the entire scheme. ${ }^{210}$ Cecil expressed particular displeasure at Smith's procuring of $£, 50$ from Ferrers and charging it to his account. ${ }^{211}$ Nevertheless, if Smith could

precisely and upon you uttermost peril undertake within a shorte tyme ... [to] accomplyshe you[r] promise as yt is already sett downe under your hand, whereupon you maie return without hazard or despleasure. ${ }^{212}$

It is clear from the tone of his letter that Cecil had no great hopes of this happening. ${ }^{213}$ Smith procrastinated in Germany and attempted to redeem himself by selling the materials to the Duke of Brunswick, a prominent supporter of chemical medicine. ${ }^{214}$ Heavily indebted, Smith eventually heeded Ferrers' calls to return to Stade, where he was arrested and sent to England. ${ }^{215}$

Hearing of Peterson's complaints and exasperated with Smith's empty promises, Cecil directed Ferrers to deliver the materials to Peterson and to retrieve the bond given for

\footnotetext{
${ }^{207}$ Cecil to Robert Smith, 4 October 1595, TNA, SP 12/254/4.

208 Ibid.

209 Ibid.

210 Ibid.

211 Ibid.

212 Ibid.

${ }^{213}$ Cecil to Thomas Ferrers, 16 November 1595, in Roberts (ed.) CMS, Vol. 5: 1591-1595, p. 458.

${ }^{214}$ Hugh Trevor-Roper, Europe's Physician: The Various Life of Sir Theodore de Mayerne, New Haven, 2006, p. 22.

215 Thomas Ferrers to Cecil, 18 May 1596, TNA, SP 12/257/89.
} 
payment. Peterson refused them; he needed the money not the materials. Considering the Queen's side of the bargain complete, Ferrers, declared that neither he nor the Queen were liable to pay the $f, 500 .{ }^{216}$ To ensure that "her majesty and my selft to be cleerily discharged and free from all intereste, damages, losse, or costes" associated with the materials, Ferrers deposited the materials with the Senate of the town. ${ }^{217}$

Peterson argued that far too much time had gone by for the return of the materials to suffice. He obtained a letter from the Council of Lubeck, requesting fair treatment for their citizen. ${ }^{218}$ Ferrers simply told Peterson that the issue was out of his hands. Peterson then wrote letters to the Queen, Cecil and Wilkes, "beseechinge her majesties favor, in comandinge Mr Deputy to see me contented". ${ }^{219}$ Ferrers, however, refused to deliver these letters. $^{220}$

By August 1597, Peterson had taken his complaint to the Holy Roman Emperor, Rudolf II. The Emperor in turn commanded Ferrers and fourteen English merchants to travel to Prague to present their case by January $1598 .^{221}$ The outcome of the suit is unclear. Peterson wrote to one of the merchants, Robert Towerson, whom he still considered a friend, on 16 October 1597, stating that he also hoped to bring the matter to trial before a "higher power" in the Court of the Bishop of Speyer. ${ }^{222}$ These lawsuits evidently worried Cecil; his scribbled notes of the urgent business concerning the 29 November 1597 session of the Privy Council included "The case of Peterson; The Cause of Stoade[Stade]; Letters from Ferrer". ${ }^{223}$ Cecil consulted with the experienced diplomat, and former adversary of Edward Kelley, Christopher Parkins, on the matter. Parkins replied that the Queen would "do hyr self wronge, yf de facto any powre be yealded to

\footnotetext{
216 Protest of Ferrers. SP 12/254/46.

217 Ibid.

${ }^{218}$ Roloff Peterson to Robert Towerson, 16 October 1597, TNA, SP 12/264/147.

${ }^{219}$ Ibid.

220 Ibid.

221 Pronouncement by Emperor Rudolf II, 17 August 1597, TNA, SP 80/1 f.211r.

222 Peterson to Towerson, SP 12/264/147.

${ }^{223}$ Memorial by Cecil, 29 November 1597, TNA, SP 12/265/22.
} 
Spira[Speyer]" as they had no authority over her royal person. ${ }^{224}$ Therefore as Peterson's dealings with English merchants had proved himself an "infamous person", Ferrers should

Pick owt som[eone] emulous of Peeterson at Loubecke to sett a worke agayst him, wherby he myght be diverted from this business and so helpt to the buryinge of that hyr majesties action. ${ }^{225}$

Perhaps Ferrers succeeded in embroiling Peterson in a legal battle and thereby 'burying' the issue, as no more is heard on the matter.

While the controversy surrounding Peterson did not involve any actual attempt at transmutation, the affair is significant in its confirmation of both the Elizabethan Court's acceptance of alchemical transmutation, and their knowledge of the value of alchemical equipment. Cecil and Sir Thomas Wilkes played the primary roles in arranging and managing the agreements with Peterson and Smith. Despite Cecil's initial claims of ignorance, the evidence points to him supervising Wilkes and Smith. It is important to note the interest in the alchemical possibilities of Peterson's materials shown in Smith's original instructions to collect "all such writings, books and papers ... which in any way treate of the arte of Alchemy", ${ }^{226}$ Although Smith promised to be able to sell the materials for the Crown, Cecil's first concern was to gather all of Oldfield's alchemical knowledge and equipment, in order to ascertain the possibility of an alchemical breakthrough. Only once the Crown's alchemical experts had analysed the materials, and considered them to be of no value, was Smith given permission to bargain for their sale. The very fact that the Court had access to sufficiently knowledgeable experts reveals their trust in alchemical practitioners. Smith's attempts to sell the material further illustrate the value of alchemical knowledge and equipment in the period. For Elizabeth and the Privy Council to risk

${ }^{224}$ Christopher Parkins to Cecil, 2 December 1597, TNA, SP 12/265/37.

225 The Privy Council had earlier assigned Parkins the case of the English Merchant Peter Gerard who was owed money by the city of Hamburg. Apparently Peterson had also involved himself in this dispute. See Parkins to Cecil SP 12/265/37 and Privy Council to Dr. Christopher Parkins, 22/05/1597, APC Vol. 27, pp. 146-147.

226 Anon. to Smith, SP 12/247/72. 
Smith's plan, they must have been relatively confident it would attract the interest of one of the German princes.

Cecil attempted to find ambitious alchemical solutions to resolve the English Crown's two most pronounced periods of financial strife. Whilst he recognised the inherent risks of such ventures, he never doubted the possibility of alchemical transmutation. During these periods the risk of being deceived by an alchemical pretender were outweighed by the urgent needs of the Treasury.

From 1564 until 1567 Cecil played the key role in instigating and overseeing Cornelius de Lannoy's transmutational scheme. Despite the later involvement of Leicester, it was clearly Cecil's project. While de Lannoy's failure was a bitter disappointment-one that Cecil did not readily forgive the alchemist for-unlike his Queen, Cecil was not dissuaded from the potential of transmutation.

Cecil's many attempts to orchestrate Edward Kelley's return to England are perhaps the most remarkable evidence that he believed alchemy could be a legitimate solution to England's desperate financial situation. Cecil's letters to both Kelley and his European informants, whilst cautious in their offers, demonstrate the great hopes he had for the alchemist's abilities. He sincerely believed that alchemical transmutation could help England withstand its perilous war with Spain. Cecil's involvement in the intrigues surrounding Roloff Peterson's alchemical vessels—only a few months after the collapse of English hopes in Kelley_demonstrate that Kelley's demise did not dissuade him from this belief. The Court's first instinct was to utilise the materials in order to perform alchemy themselves. Only after the vessels were tested by alchemical experts and declared fraudulent, did Cecil orchestrate the attempts to sell them in Europe. These examples demonstrate Cecil's belief that alchemy had the potential to be a panacea to England's financial problems. However, Cecil's patronage of alchemy was not limited to periods of 
government desperation. Chapter four therefore examines Cecil's attempts to utilise alchemy to aid in the improvement of the English economy. 


\section{Chapter Four: Alchemy and Economic Projects}

Whilst the relatively prosperous state of Crown finances during 1570s and early 1580s removed the urgent need for gold, Cecil did not ignore the potential of alchemical enterprise. Rather, alchemy played a role in his attempts to improve England's industrial competitiveness. First as Principal Secretary, then as Lord Treasurer from 1572, Cecil initiated, supported and monitored a number of schemes intended to strengthen and expand the English economy. Cecil considered economic development to be a central factor in ensuring the security of England in an increasingly hostile European political climate. As distinct from Cecil's attempts to secure Crown finances, his industrial projects often had broader aims and a more distinct sense of coherent policy making. Both Elizabeth and Cecil were obsessed with securing the position of a Protestant England through the patronage of large scale industrial projects. These projects would reduce England's economic dependence on imports from Catholic Europe, which could not be relied on in times of war. In this way they complemented an increasingly Mercantilist understanding of the economy, as contemporaries believed that securing a positive balance of trade was essential to increasing England's share of the fixed amount of available wealth.

The historical debate surrounding Elizabethan economic initiatives has focused on whether Cecil had a clearly defined economic policy. Historians such as Norman Jones have argued that Cecil had no real understanding of the economy, and that he adhered instead to the medieval belief that "the economic ills of the country grew out of greed, social climbing and lack of discipline". Recently, however, Felicity Heal and Clive Holmes, through cataloguing the patterns of Cecil's economic patronage, have persuasively argued that Cecil had a more cohesive understanding of the economy. They maintain that

\footnotetext{
${ }^{1}$ Norman L. Jones, 'William Cecil and the Making of Economic Policy in the 1560s and Early 1570s' in Paul A. Fiddler and Thomas J. Mayer, (eds.), Political Thought and the Tudor Commonwealth, London, 1992, pp. 172-73.
} 
Cecil "had clear general aims in his desire to strengthen and stabilize the realm and make it more wealthy".2

This chapter argues that, whilst Heal and Holmes' conclusions are convincing, they did not accord sufficient importance to Cecil's patronage of alchemical schemes. To do so it examines the role of alchemy in two of Cecil's economic projects. Firstly it considers the role of two alchemists in promoting the Frobisher Voyages, and Cecil and the Elizabethan Court's responses to their alchemical methods. Secondly it examines in depth Cecil's lengthy patronage of the industrial alchemist William Medley, including an analysis of the Society of the New Art's attempts to establish an English copper industry using transmutation. Neither of these episodes has been properly explained by historians.

\section{The Frobisher Ores}

The curious alchemical connotations of the Frobisher voyages between 1576 and 1578 provide a significant example of the link between alchemy and state sponsored industrial development. On his first voyage to the far north of the New World, Martin Frobisher's discovery of ore supposedly rich in gold and silver created a frenzy of speculation at the English Court. Two alchemists, Giovanni Baptista Agnello and Burchard Kranich, were integral to the promotion of Frobisher's speculative second voyage, the first to attract substantial Court investment. The evidence shows that not only was Cecil, one of the lead investors, aware of the alchemical practices of the project's two lead chemists, but that their alchemical skills would have made the economics of the scheme more palatable for the Lord Treasurer.

Historians have not previously understood the connection between alchemy and the assaying of the Frobisher ore. It has only been in the last fifty years that the project has garnered any scholarly attention. Much recent work, such as the two-volume collection of

\footnotetext{
${ }^{2}$ Heal and Holmes, 'The Economic Patronage of William Cecil', p. 223.
} 
essays Meta Incognita: A Discourse of Discovery: Martin Frobisher's Arctic Expedition (1999), has focussed on Frobisher's voyages, with only a passing reference to the metallurgical work carried out in England. ${ }^{3}$ James McDermott's otherwise comprehensive biography of Frobisher makes no mention of any of the assayer's alchemical interests, referring to Agnello only as a goldsmith and Kranich as a physician. ${ }^{4}$ Others, notably the geologist D. D. Hogarth, have examined the voyages primarily from a scientific viewpoint, examining both the ore remaining in England and the mining sites in Canada. ${ }^{5}$ Through an examination of the related manuscripts, details of the processes used by the assayers have also been revealed. ${ }^{6}$ Whilst these studies, especially D. D. Hogarth, P. W. Boreham and J. G. Mitchell's Martin Frobisher's Northwest Venture, 1576-1581: Mines, Minerals \& Metallurgy (1994), give some historical background and a clear description of the actions of those involved, their analysis of the project's historical significance is limited, and they fail to appreciate the importance of alchemy for the scheme. ${ }^{7}$

To date, Deborah Harkness' The Jewvel House: Elizabethan London and the Scientific Revolution (2007) is the only work that puts the Frobisher Voyages in the context of Cecil's penchant for alchemical patronage. For Harkness, the project was one of many demonstrating Cecil's use of London's proto-scientific community for large scale industrial projects. However, in forming her argument she utilised some dubious evidence. Much of Harkness' argument hinged on her identification of an Italian, Giovanni Battista da Trento, as Giovanni Baptista Angello. A state paper written in Italian and signed by Cecil on 15 January 1577, records that da Trento met Cecil and offered to reveal many important secrets. ${ }^{8}$ Harkness interprets this meeting, immediately after Agnello' first alchemical assay

\footnotetext{
${ }^{3}$ Thomas Symons (ed.), Meta Incognita: a Discourse of Discovery: Martin Frobisher's Arctic Expedition, Hull (PQ), 1999.

${ }^{4}$ James McDermott, Martin Frobisher: Elizabethan Privateer, New Haven, 2001, pp. 153-154, 199.

${ }^{5}$ D. D. Hogarth, P. W. Boreham and J. G. Mitchell, Mines, Minerals \& Metallurgy: Martin Frobisher's Northwest Venture, 1576-1581, Hull (PQ), 1994; D. D. Hogarth and John Loop, 'Precious Metals in Martin Frobisher's “Black Ores” From Frobisher Bay, Northwest Territories', Canadian Mineralogist, Vol. 24, 1986.

${ }^{6}$ Hogarth, Boreham and Mitchell, Mines, Minerals \& Metallurgy, 1994, pp. 73-100.

${ }^{7}$ Ibid.

${ }^{8}$ Harkness, The Jewel House, pp. 143, 282 n.
} 
of the Frobisher ore, as proof that Cecil was involved in an obviously alchemical scheme. ${ }^{9}$ Unfortunately, Harkness' identification is incorrect, as da Trento was, in fact, a former agent of the Cardinal of Lorraine, who wisely moved to England after providing Cecil with confidential information. ${ }^{10}$ The meeting probably related to the 1577 letter he wrote to the Queen accusing the Earl of Leicester of murdering his wife. ${ }^{11}$

No other historian has studied Cecil's links to the three Frobisher voyages in any detail; his biographers barely mention the project. This was possibly due to Cecil's ambiguous role, as he became involved in the scheme as one of many prominent Court investors, rather than as the primary promoter. He is however, known to have promised $£ 400$ towards the enterprise, and clearly believed that Frobisher's ore would provide a handsome profit. Cecil demonstrated a significant interest in the metallurgical aspect of the project, and had a diagram of the alchemist Burchard Kranich's furnace drawn for him (image 2). He was also the key Court figure in arranging the construction of works in Dartford, where the ore was to be smelted. The Frobisher voyages are therefore an important case study of Cecil's willingness to utilise alchemy to aid the English economy.

In October 1576 Frobisher returned from his first voyage to what is now known as Frobisher Bay in the north-east of Canada. His intention had been to discover the northwest passage to the mythical spice islands of Asia. Thwarted by arctic weather and hostile natives, he presented his principal sponsor, the London merchant Michael Lok, with only a piece of black ore "as great as a halfpenny loaf". ${ }^{12}$ It is uncertain why Lok chose to have the ore assayed. The explanation of George Best, a member of the crew, seems rather fanciful. According to Best, Lok gave a piece to his wife, which

\footnotetext{
${ }^{9}$ Ibid., pp. 174-75.

10 SP 12/111/2; N. M. Sutherland, The Massacre of St. Bartholomew and the European Conflict 1559-1572, London, 1973 , p. 113.

11 The letter also accuses Leicester of being involved in a number of other traitorous plots. 'A long and fantastical invective against, and accusation of, several great persons for treason; sent to the Council, by Jo. Baptista, an Italian', BL, Lansdowne Vol /99 f.96; , Frederick Chamberlain, Elizabeth and Leycester, London, 1939, p. 18.

12 Michael Lok., May 1579, TNA, SP 12/131/20.
} 
by chance she threw and burned in the fire, so long, that at the length being taken forth, and quenched in a little vinegre, it glittered with a bright Marqeusset of golde. Wherupon ye matter being called into some question, it was brought to certain Goldfinders in London, to make assay therof who indeed found it to hold gold, and that very ritchly for the quantity. ${ }^{13}$

The issue was in fact far more complicated than this tale would lead us to believe. The first three assay masters who examined the stone declared it merely marcasite, or iron sulphide. ${ }^{14}$ Disheartened, Lok waited until the beginning of January 1577 to give a piece to the Italian alchemist Giovanni Baptista Agnello. ${ }^{15}$

Cecil had known of Agnello for some time. Born in Venice, Agnello was first recommended to Cecil by Richard Eden's patron the Vidame de Chartres during a visit to London in late 1569. The Vidame wrote to Cecil recommending "Messer Giovanni Baptista Agnelli as a man of honesty and industry" and sent the Principal Secretary a copy of Agnello's book Espositione Sopra un Libro Intitolato Apocalypsis Spiritus Secreti (1566). ${ }^{16}$ First published in London in Italian and Latin, Richard Napier translated the work in 1623 as Revelation of the Secret Spirit of Alchymie, describing it as "much esteemed amongest the learned in Italy" and as being useful "in the practical search of that Chrystalline central Salt". ${ }^{17}$ The book was in two parts; the first contained Agnello's "short Exposition and allegation of sentence of the best Philosophers" including Raymond Lull, Arnold of Villanova, George Ripley and Hermes Trismegistus; the second included what Agnello claimed to be a reproduction of an unsigned alchemical treatise that he considered "in sentecne and learning most grave". ${ }^{18}$ The Vidame further enticed Cecil with the suggestion that "perchance his kindness may be returned by an ounce or so of powder of

\footnotetext{
${ }^{13}$ George Best, A True Discourse of the Late Voyages of Discoverie, for the finding of a passage to Cathaya, by the Northweast, under the conduct of Martin Froblisher Generall, London, 1578, p. 51.

14 Michael Lok to Queen Elizabeth, 22 April 1577, TNA, SP 12/112/25.

${ }^{15}$ Ibid.

16 The Vidame's suggestion that Cecil favour Agnello, probably refers to a plan Agnello had presented to the Queen in 1569, to remedy the scarcity of England's smaller coins by coining lead testons. There is no evidence of a response to his proposal. The Vidame de Chartres to Cecil, 4 November 1569, in Crosby, CSPF 1569-71, p. 142; Giovanni Baptista Agnello to Queen Elizabeth, 1569, in CSP Foreign 1569-71, p. 163.

17 Giovanni Baptista Agnello, Revelation of the Secret Spirit of Alchymie, Richard Napier (trans.), London, 1623, pp. v,vi.

${ }^{18}$ Ibid.
} 
transmutation". ${ }^{19}$ Having employed Cecil's former secretary Richard Eden, the Vidame clearly knew of Cecil's pronounced interest in alchemy.

Agnello's previous government career and associations within Elizabethan society suggest that Cecil probably knew of the Venetian alchemist prior to the Vidame's recommendation. Little is known of Agnello's earlier life. Agnello had certainly arrived in England by the reign of Edward VI, when in 1548-9 John Baptista Agnelli \& Company of Venice were authorised to supply the mint with bullion. ${ }^{20}$ At a time when Cecil was at the heart of the Duke of Somerset's government, Agnello provided a valuable service, bringing in 15,000 pounds weight of fine silver within seven months, before piracy and a lowering of the mint's price forced him to cease. ${ }^{21}$ Agnello was one of a few entrepreneurs who took full advantage of the Treasury's desperate need for bullion in order to produce more debased currency, and likely enriched himself considerably as a result. Deborah Harkness has also identified Agnello as likely being the "Johanni Baptistae Danieus" who gave John Dee a copy of Pantheus' Voarchadumia in 1559; a contention supported by the fact that Dee owned a copy of Agnello's Apocalypsis. ${ }^{22}$ If so it would appear that Agnello was another Elizabethan alchemist, like John Dee, Cornelius de Lannoy and Francis Thynne, influenced by Pantheus' alternative alchemical procedures.

Within three days of receiving the ore Agnello returned to Lok with remarkable results. From his tiny sample he had extracted "a very letle powder of Gold". 23 Agnello claimed that he had succeeded where the other experts had failed because he better understood how to flatter nature, words that suggest the use of alchemical methods. ${ }^{24}$ Certainly Sir Francis Walsingham, to whom Lok was secretly reporting, considered it "to be but an Alchamist matter suche as dyvers others before had byn brought to your Majesties

\footnotetext{
${ }_{19}$ The Vidame de Chartres to Cecil, in Crosby (ed.), CSPF 1569-71, p. 142.

${ }^{20}$ He may be the Venetian, John Baptiest, granted denization in 1541, See Pelling Medical Conflicts, p. $307 \mathrm{n}$.

${ }^{21}$ Challis, The Tudor Coinage, p. 181.

22 Deborah Harkness, John Dee's Conversations with Angels, Cambridge, 1999, p. 204n.

${ }^{23}$ Lok to Elizabeth, SP 12/112/25.

${ }^{24}$ Ibid.
} 
by others without trewthe". ${ }^{25}$ Walsingham had Edward Dyer-who already had considerable alchemical experience many years before his involvement with Edward Kelley-examine another sample of the ore. Dyer, however, could detect only a little silver. Walsingham, therefore, again derided the whole scheme as "but the devyses of Alchamiste".

Others at Court seem to have put considerably more stock in Agnello's claims. When Lok informed Agnello that they would need a license to mine the ore, Agnello assured him that he "had a frynd in the Courte by whose meanes he would move [her] majesty therof', and who could also provide funding. ${ }^{26}$ It is certainly not inconceivable that Agnello hoped to rely on his influence with Cecil. Regardless, Agnello's lack of discretion ensured that the news of Frobisher's discovery rapidly spread throughout London. As enthusiasm for the project spread, Jonas Schutz, a German metallurgist, joined Agnello in several assessments of the black ore's value. ${ }^{27}$ To the Elizabethans there was no contradiction in having Agnello, a professed alchemist, "prepare the ewer too greate effecte", while the German metallurgist Shutz supervised the furnaces. ${ }^{28}$ The two practices were considered inextricably linked, based upon the same unified theory of nature. To the delight of the Elizabethan Court, the ore apparently contained recoverable gold to the value of $f_{2} 240$ per ton, promising huge profits, in excess of Agnello's original assessment. ${ }^{29}$

The potential gains caused feverish excitement at Court and a second voyage was quickly arranged. Most of the London merchants who had funded the first voyage had, however, pulled out, judging the venture too risky. ${ }^{30}$ The Court therefore supplied almost all the capital for the second voyage. Cecil invested $£_{4} 400$ in the enterprise, Leicester $f_{6} 600$, and Walsingham, despite his doubts, $£ 800$, while the Queen's contribution of several

\footnotetext{
${ }^{25}$ Ibid.

${ }^{26}$ Ibid.

27 Ibid.

${ }^{28}$ Ibid.

${ }^{29}$ Hogarth, Boreham, Mitchell, Mines, Minerals \& Metallurgy, p. 73.

${ }^{30}$ Deborah Harkness, The Jewel House, p. 168.
} 
vessels was valued at over $f 4,000 .^{31}$ The courtiers expected a massive return on their investments.

All those involved would be disappointed. Frobisher could not find any ore in the previous location, and instead mined over 158 tons of ore from nearby Baffin Island. ${ }^{32}$ When Frobisher returned to England in September 1577, the government stored the ore under intense security in Bristol. ${ }^{33}$ It seems that in the mean time Agnello had been replaced as the chemical expert for the assays by the Queen's German doctor Burchard Kranich, often referred to by contemporaries as Dr. Burcot. Kranich had been involved in English mining ventures from at least 1553 , without success. ${ }^{34}$ There is little information about his medical practice, although Gervase Markham's The English Housewife (1615) attributed various chemical medicines to a manuscript supposedly written by both Kranich and Cecil's physician Eliseus Bomelius. ${ }^{35}$

Two previously overlooked pieces of evidence suggest that Kranich also brought alchemical knowledge to bear on the ore. Firstly, in Richard Eden's 1573 appeal for a license to practice alchemy, he cites the example of one "Brocardus", a Latinised version of Burchard, as a foreigner who was allowed to attempt transmutation unhindered. ${ }^{36}$ That there were no other prominent Burchards in England at the time suggests that Eden thought Kranich was engaged in alchemy. Secondly, Reginald Scot in his chapter devoted to debunking alchemists within Discoverie of Witchcraft (1584), focused on the "manie alcumysticall cousenages wrought by Doctor Burcot". ${ }^{37}$ These, along with Kranich's prominent position as a Court physician, suggest that his alchemical knowledge would have been well known to the investors who appointed him. Stanton J. Linden's study of Scot's

\footnotetext{
31 Ibid., pp. 12-22.

32 Ibid, pp.34-37.

33 Ibid, p.35.

${ }^{34}$ John Bennell, 'Kranich, Burchard (d. 1578)', Oxford Dictionary of National Biography, Oxford, Sept 2004; online edn, Jan 2008 [http://www.oxforddnb.com/view/article/52152].

35 Gervase Markham, Michael Best (ed.), The English Housewife, London, 1615, Reprinted, 1994, p. 8.

${ }^{36}$ Richard Eden to Queen Elizabeth, 1572, Reprinted and trans. in Arber (ed.), The First Three English Books on America, pp xlv; Aziz Suryal Atiya, The Crusade in the Later Middle Ages, London, 1938, p. 95.

${ }^{37}$ Reginald Scot, The Discoverie of Witchcraft, 1584, reprinted New York, 1989, p. 209.
} 
work did not make this link, and neither have John Bennel's Oxford Dictionary of National Biography entry for Kranich, or M. B. Donald's article, 'Burchard Kranich (c. 1515-1578), Miner and Queen's Physician, Cornish Mining Stamps, Stamps, Antimony and Frobisher's Gold' (1950). ${ }^{38}$

Widely differing in both technique and attitude, Kranich and his fellow German, Schutz, began exchanging insults almost straight away. Kranich accused Schutz of "ingnorance and unskylfulnes" and Shutz accused Kranich of using additives to artificially inflate his results. ${ }^{39}$ Within a few weeks they refused to have anything to do with one another. $^{40}$ Their initial assays did, however, prove to be reasonably successful, prompting the funding of a third voyage. ${ }^{41}$

With relatively successful results from the initial small scale assays, and another voyage planned, Cecil arranged for a major smelting works to be built in Dartford, Kent. He employed Thomas Fludd, father of the occultist Robert Fludd, as surveyor of the works, which were completed by November $1578 .^{42}$ By this time Kranich had died and Frobisher's third voyage had returned with another 1100 tons of ore. ${ }^{43}$ This, however, was the point at which the project began to take a turn for the worse. Schutz's first bulk assay at Dartford, on 13 November 1578, revealed no significant amounts of either gold or silver. $^{44}$ Blaming first his equipment, then the ore itself, Schutz made another four assessments —all returned similar results_-the ore was worthless. ${ }^{45}$ According to Lok, at this time "the Ewre brought home by Captain Furbisher grewe into great discredit". 46

\footnotetext{
${ }^{38}$ M. B. Donald, 'Burchard Kranich (c. 1515-1578), Miner and Queen's Physician, Cornish Mining Stamps, Antimony and Frobisher's Gold', Annals of Science, Vol. 6, No. 3, 1950, pp. 308-22.; Bennell, 'Kranich, Burchard (d. 1578)'; Stanton J. Linden, Dark Hierogliphicks: Alchemy in English literature from Chaucer to the Restoration, Lexington, 1996, p. 83.

${ }^{39}$ Burchard Kranich to Francis Walsingham, 27 February 1578, TNA, SP 12/122/61.

${ }^{40}$ Kranich to Walsingham, SP 12/122/61; Jonas Schutz, February 1578, TNA, SP 12/122/62.

${ }^{41}$ Hogarth, Boreham, Mitchell, Mines, Minerals \& Metallurgy, pp. 74-75.

${ }^{42}$ Thomas Fludd to Cecil, 7 January 1578, TNA, SP 12/122/4.

${ }^{43}$ Hogarth, Boreham, Mitchell, Mines, Minerals \& Metallurgy, pp. 47.

44 Ibid., pp. 74-75.

${ }^{45}$ Ibid.

${ }^{46}$ Lok., SP 12/131/20.
} 
The Frobisher voyages and the associated industrial scale assays had come at huge expense. According to Hogarth et al, "they had cost $f 19,200$, two ships, about 22 boats and pinnaces, and at least 24 lives". ${ }^{47}$ Whilst Lok bore the brunt of the financial cost, Court investors were loath to accept such a failure, and assays of the ore continued until July 1583. ${ }^{48}$ Eventually the ore was abandoned as worthless. ${ }^{49}$

The project does, however, reveal several characteristics about the Elizabethan Court's attitude to alchemy. Two of the assayers of Frobisher's ore were alchemists of some repute: a fact that does not seem to have dissuaded the majority of England's courtiers and politicians from investing in the scheme. In fact they may have seen alchemy as necessary for the success of the project. News of the precious metal content of the ore had surprised both English courtiers and Spanish spies. It conflicted with their understanding of gold and silver as 'hot' metals which required intense occult influences from the sun to be formed in the earth. ${ }^{50}$ They could not form in colder climates such as Baffin Island. Sir Philip Sidney, an alchemical pupil of John Dee and friend of Edward Dyer, who invested $£^{200}$ in the project, expressed his surprise that "precious metals were produced in a region so far to the north", whilst the Spanish Ambassador wrote to King Philip II, observing that "it is incomprehensible that a land so cold as this can produce anything". ${ }^{51}$ From this perspective, the involvement of alchemists, with their experience in simulating the solar heat by which metals were thought naturally to transmute, would have logically been advantageous.

In many ways the Frobisher voyages demonstrate the difficulty in differentiating between alchemy and chemistry in the period; to contemporaries they were inextricably

\footnotetext{
47 Hogarth, Boreham, and Mitchell, Mines, Minerals \& Metallurgy, p. 52.

48 Ibid., pp.93-94.

49 Donald Hogarth and John Loop's study of the minerals from the location of Frobisher's mine determined the ore to be primarily Hornblend, containing quantities of silver and gold around one thousandth of that suggested by Agnello, Shutz and Kranich. See Hogarth and Loop, 'Precious Metals', pp. 261-62.

50 Georgius Agricola, De Re Metallica, 1556, Hebert Hoover (trans.), London, 1912, p. 44.

51 Philip Sidney to Hubert Languet, 1 October 1577, in Philip Sidney and Steuart A. Pears(eds.) The

Correspondence of Sir Philip Sidney and Hubert Languet, Steuart A. Pears (trans.), London, 1845, p. 119; Don

Bernardino de Mendoza to King Philip II, 15 November 1578, quoted in James McDermott, Martin Frobisher:

Elizabethan Privateer, New Haven, 2001, p. 157.
} 
linked. It is, however, significant that Cecil chose to invest so heavily, and take such an active role in the organisation of the scheme. He had extensive knowledge of both Agnello and Kranich's alchemical interests and willingly ventured a significant portion of his own fortune on the possibility of success. Cecil seems to have shared Philip Sidney's opinion that Frobisher's discoveries "seem very far to surpass the country of Peru" where the Spanish obtained immense quantities of silver from Potosi. ${ }^{52}$ Like so many others at the Court, Cecil looked on the Frobisher voyages as a way of emulating the enormous wealth accumulated by the Spanish in South and Central America. It seems that Cecil thought that England, with the aid of a little alchemical coaxing, could also reap the profits of the New World.

52 Sidney to Languet, in Sidney and Pears(eds.) The Correspondence of Sir Pbilip Sidney, p. 119. 


\section{Image 2:}

Labelled 'Burchart's furnice' in Cecil's hand.

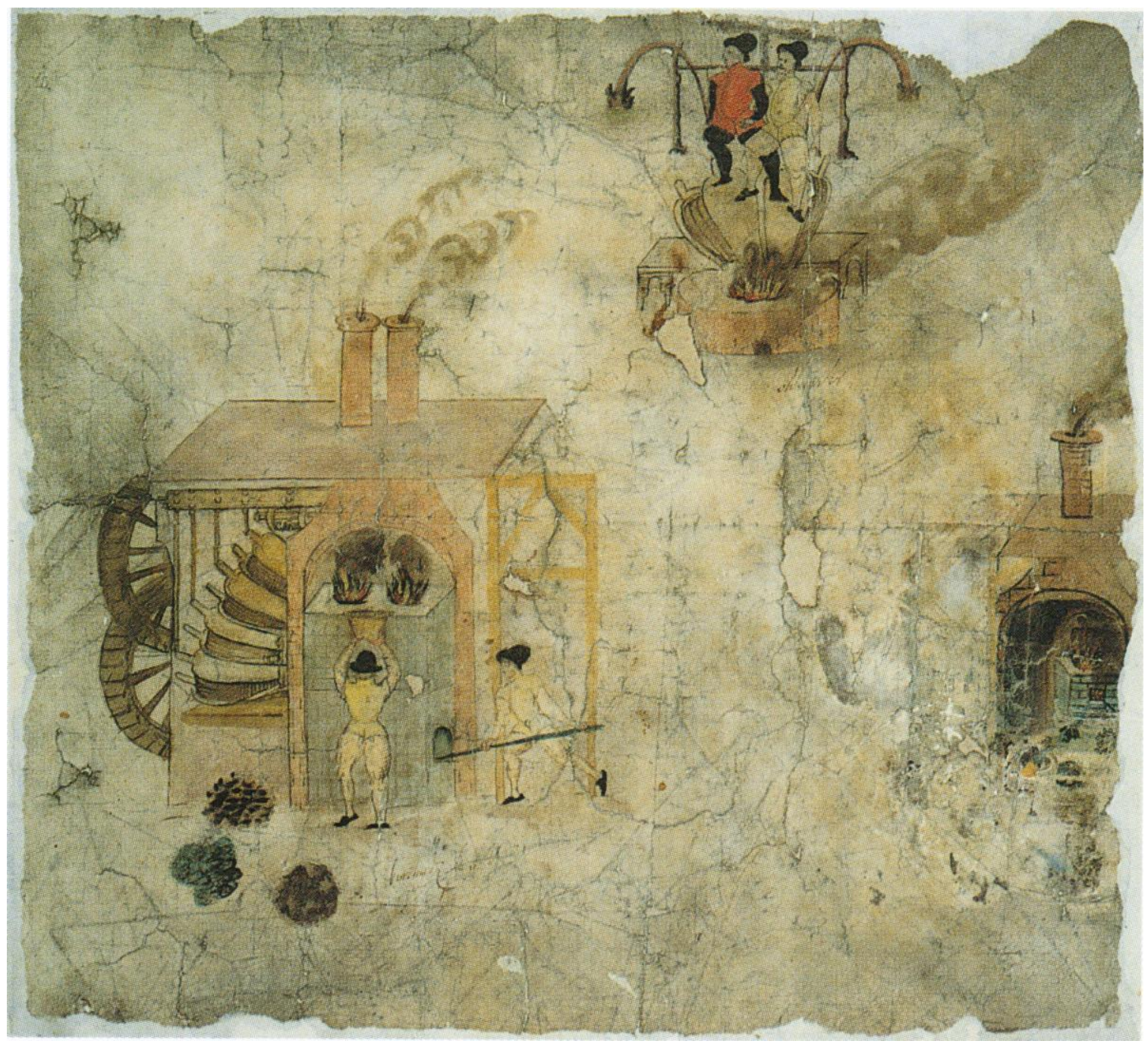

Source: Anon., Undated, TNA, SP 12/122/63.

\section{William Medley and the Society of the New Art}

Cecil's patronage of the industrial alchemist William Medley provides the most important example of his use of alchemy as a legitimate tool to improve England's industrial competitiveness. With the backing of a number of prominent courtiers and politicians-including Cecil-Medley attempted to transmute cheap and abundant iron into valuable copper from 1571 until 1576. Incorporating themselves as the Society of the New Art, Medley's powerful patrons obtained a patent for the process. On two occasions, 
blaming betrayal, setbacks and deception, Medley failed to produce a return on their investment, and was eventually imprisoned.

Historians of the Society have seen it is as the inevitable end of a charlatan, echoing the assessment of John Strype's The Life of the Learned Sir Thomas Smith (1698). ${ }^{53}$ Strype's very broad account glossed over many of the project's details, and provided no analysis of its importance. He relied on two letters written by Thomas Smith and William Medley to Cecil explaining their role in the scheme, both of which omit significant elements of the project. ${ }^{54}$ Because he overlooked the extensive correspondence between these men, Strype neither grasped the true size and scope of the project, nor the amount of support and financing it garnered from the Elizabethan Court. Strype also ignored William Medley's biographical background, and assumed that the alchemist met his just ends imprisoned for debt. ${ }^{55}$ As an early enlightenment intellectual Strype struggled to reconcile the intellectual ability of men like Smith and Cecil with their support for such an irrational scheme. He concluded that the project's main achievement was to teach otherwise wise and admirable men "to trust little to words and promises, nor to experiments made afar off, nor to the accounts of men of that faculty [alchemy]". ${ }^{56}$ Strype's analysis, weighed down with all the scientific age's derision for an age of superstition, depicted the project as an embarrassing example of the lingering ignorance that pervaded Elizabethan society.

Modern political historians have paid little real attention to the Society of the New Art and have been largely content to follow Strype in castigating it as a transparent fraud. Mary Dewar's biography of Sir Thomas Smith provides probably the most thorough examination of the project to date. ${ }^{57}$ Using a much wider range of sources than Strype, Dewar's account goes into greater detail, but essentially tells the same story. Her chronology of events is generally correct, but Dewar ends her account with Medley trying

\footnotetext{
${ }^{53}$ John Strype, The Life of the Learned Sir Thomas Smith.

${ }^{54}$ It seems that Strype's two sources for his account were: William Medley to William Cecil, 19 April 1572

TNA SP12/86/14; and Thomas Smith to William Cecil, 15 December 1574, Lansdowne Vol. 19, No. 45.

55 Strype, The Life of the Learned Sir Thomas Smith, p. 105.

56 Ibid., p. 105.

${ }^{57}$ Mary Dewar, Sir Thomas Smith, London, 1964, pp. 149-55.
} 
to ingratiate himself with Cecil and blaming the project's setbacks on Sir Humphrey Gilbert. The letter she cites in support of this claim, however, was written over three years before the end of the project. $^{58}$ Moreover, Dewar failed to uncover anything about Medley's background or subsequent career in Cecil's service, and instead accepted Strype's depiction of him as a deluded and marginal figure. Dewar and other historians have emphasised Medley's imprisonment as a natural result of his 'wild' schemes, ignoring the evidence of a much more interesting and significant background struggle for alchemical patronage. This evidence suggests that Medley was the victim of a campaign of subterfuge set in motion by those jealous of his monopoly over alchemical patronage.

As biographers of Smith, Strype and Dewar naturally focussed on Smith's role in the scheme, discussing Cecil only tangentially. Biographers of Cecil have relegated Medley and the Society of the New Art to little more than a footnote. To Conyers Read the project "came of course to nothing" showing only "that like all his fellows even Burghley succumbed on occasion to the alluring promises of the alchemists", ${ }^{99}$ B. W. Beckingsale's mentions only that Cecil was a shareholder in the Society, a company "concerned with new techniques in mining and metallurgy". ${ }^{60}$ Cecil's two most recent biographers, Michael Graves and Stephen Alford, completely omit William Medley and the Society of the New Art. $^{61}$

Medley's process has attracted more attention from historians of science and industry. J. W. Gough's The Rise of the Entrepreneur (1969) briefly outlined the project and put it into the context of the various schemes to created alum (hydrated aluminium potassium sulphate). ${ }^{62}$ Gough, however, was not interested in Cecil's involvement in the scheme, and in fact misunderstood Medley's second 'transmutational' process, believing it

\footnotetext{
${ }^{58}$ Ibid., p. 155.

59 Read, Lord Burghley, p. 145.

${ }^{60}$ Beckingsale, Burghley, p. 261.

${ }^{61}$ Graves, Burghley; Alford, Burghley.

${ }^{62} \mathrm{~J}$. W. Gough, The Rise of the Entrepreneur, New York, 1969, pp. 181-183.
} 
to involve cementation rather than precipitation. ${ }^{63}$ M. B Donald in Elizabethan Monopolies (1961) discussed the involvement of Cecil's technical expert, William Humfrey, in the scheme. ${ }^{64}$ While Donald correctly understood Medley's chemical process, he provided little detail or context for the project, and continued to describe William Medley as a charlatan. ${ }^{65}$

Recent examinations of Cecil's patronage have also failed to examine William Medley or the Society of the New Art in any detail. Felicity Heal and Clive Holmes, who only mention the project in a footnote, state that Cecil was more cautious in investing than the rest of the partners and refer the reader to Mary Dewar's work. ${ }^{66}$ Stephen Pumfrey and Frances Dawbarn's article 'Science and Patronage in England, 1570-1625' describes the Society of the New Art as "the most extraordinary of Burghley's projects", yet dismisses it in a few sentences. ${ }^{67}$ Incorrectly dating the project to 1579 , they argue that it was another example of Cecil's utilitarian patronage that concerned him because of its implications on coinage. $^{68}$ As evidence they cite John Strype's seventeenth century account. ${ }^{69}$ Although Deborah Harkness' The Jewel House does put the scheme in the context of Cecil's involvement with the Frobisher voyages and Cornelius de Lannoy, her coverage of the project is superficial and she provides no real analysis of the project's importance. ${ }^{70}$ Historians have thus constantly reiterated either John Strype or Mary Dewar's account of the project, revealing that the topic has yet to be properly researched.

As an alchemical project on an industrial scale, the Society of the New Art demonstrates how far Cecil would back his assumptions about nature with his own money and influence. Cecil's role in the creation, funding and support of the Society of the New Art has numerous important parallels to his patronage of other schemes designed to reduce

\footnotetext{
63 Ibid., p. 183.

${ }^{64}$ M. B. Donald, Elizabethan Monopolies: The History of the Company of Mineral and Battery Works 1568-1604, Edinburgh, 1961, pp. 30-33.

65 Ibid., p. 32.

${ }^{66}$ Heal and Holmes, 'The Economic Patronage of William', p. 229n.

${ }^{67}$ Pumfrey and Dawbarn, 'Science and Patronage in England', p. 159.

${ }^{68}$ Ibid., p. 160.

${ }^{69}$ Ibid., p. 185 n.

${ }^{70}$ Harkness, The Jewel House, pp. 170, 173-74.
} 
England's dependence on imports from Catholic Europe. That Medley's process was alchemical, allowing him to make "nature ripe by art", did not trouble the Lord Treasurer because Medley's process conformed to Cecil's alchemical understanding of the world. ${ }^{71}$ Throughout the project Cecil actively pressed for royal support for the scheme, and he retained confidence in Medley's potential, even as others lost patience. Medley's links to Cecil, both before and after their participation in the Society of the New Art also necessitate a thorough examination of their relationship. Medley, who clearly tied his fortunes to Cecil's, provides an almost completely unexamined example of the alchemical and metallurgical interests amongst Cecil's closely allied clients.

William Medley was no marginal charlatan, for his family background explains his links to Cecil. Medley was born into a wealthy Essex family, probably in the mid 1540s. ${ }^{72}$ The Medleys of Tilty Abbey, Essex, had strong links to many noble families, including Cecil's. William's father, George Medley (d. 1562) was the half brother of Henry Grey, Duke of Suffolk, and the second cousin once removed of Cecil's second wife Mildred Cooke. He strongly supported the Protestant faction in England, having received lucrative leases during Henry VIII's dissolution of the monasteries. ${ }^{73}$ Upon Edward VI's death, George supported the cause of his niece, Lady Jane Grey against Mary, and was one of only nine indicted with Suffolk. Unlike Suffolk, he was spared execution or even imprisonment. ${ }^{74}$ George failed to learn from his mistake, and spent two months in prison for his involvement in the Wyatt rebellion of $1554 .^{75}$ Despite the problems it caused him under Queen Mary, George Medley's “detestation of papistrie” positioned him and his family well for the return of a Protestant monarch. ${ }^{76}$

\footnotetext{
${ }^{71}$ William Medley to Cecil, 19 April 1572, TNA, SP 12/86/14.

72 Whilst we have no definitive birth date for William Medley, he was under 21 when under when his father's made out his will in 1561. 'Will of George Medley of Titly, Essex', TNA, PROB 11/46, proved 3 February 1563.

${ }^{73}$ Henry Grey to Michael Stanhope, 19 April 1551, in Scargill Bird (ed.), CMS, Vol. 1, p. 85.

${ }^{74}$ Henry Churchill Maxwell-Lyte (ed.), CPR: 1553-1554, London, 1937, pp. 381-2.

${ }^{75}$ David Loades, Two Tudor Conspiracies, London, 1965, p. 28.

${ }^{76}$ George Medley to Nicholas Throckmorton, 23 September 1561, SP 70/30/84.
} 
Clearly aware of Cecil's rising influence, George had his second son William Medley "bred up under Lord Burghley, being thereto preferred by Lady Burghley". 77 According to Read, Cecil "took a great interest in the education of promising young Englishmen. His household indeed was currently regarded as the best training school for the gentry in England". ${ }^{78}$ While nothing else is known of William's early life, he probably received a similar education to his cousins Francis and Margaret Willoughby. After their father's death in 1549 the Willoughby siblings became wards of George Medley, at a cost to him of $f_{1000}$, and were privately tutored in Latin and Greek. ${ }^{79}$ In 1575 William Medley would demonstrate his classical learning to Cecil, presenting him with a lengthy 'Discourse of Rhetoric', comprised of fifty pages of advanced discussion of Aristotelian rhetorical method in both English and Latin. ${ }^{80}$ Clearly William Medley received the humanist education appropriate to his family's social status; although there is no evidence he attended university. Having inherited a bequest for his further education upon his father's death in 1562 , by 1564 Medley had been admitted to study law at the Middle Temple. ${ }^{81}$ He also received some significant leases, cementing his place among the gentry of Essex. ${ }^{82}$

Along with Medley's training in law, at some point he developed an expertise in metallurgy-exceptionally rare among Elizabethan Englishmen. Until the 1560s the English had very limited experience with mining or metallurgy beyond the relatively straightforward production of tin, lead, and iron. ${ }^{83}$ The Germanic regions of central Europe far outstripped England in metallurgical knowledge, having introduced a number of innovations since the fourteenth century to their much more advanced mining industry. Virtually all of the mining and mineralogical treatises published in the sixteenth century

\footnotetext{
77 William Medley to Sir Robert Cecil, 3 November 1598, Roberts, R. A. (ed.), CMS. Vol. 8: 1598, London, $1899, \mathrm{p} 421$.

78 Read, Lord Burghley, pp 124-125.

${ }^{79}$ Eric Ives, Lady Jane Grey: A Tudor Mystery, Chichester, 2009, p. 37.

${ }^{80}$ William Medley, 'A Brief Discourse of Rhetoric', 1575, Hatfield House, Cecil Papers, M485/6.

81 'Will of George Medley', TNA, PROB 11/46; Charles Henry Hopwood and Charles Trice Martin (eds.),

Middle Temple Records, Volume 1, London, 1904, pp. 146, 150.

82 'Will of George Medley', PROB 11/46.

${ }^{83}$ Eric H. Ash, Power, Knowledge, and Expertise in Elizabethan England, Baltimore, 2004, pp 22-23.
} 
were written in Latin by German authors. ${ }^{84}$ Such was the German monopoly on working with more difficult metals that the Company of Mines Royal in Cumbria relied almost completely on German mining experts for their copper extraction in the mid $1560 \mathrm{~s} .{ }^{85}$ Medley could certainly read Latin, and probably had access to some of the major metallurgical works produced in Europe, but he also possessed a degree of practical expertise. $^{86}$ Though there is no evidence to prove it, Medley may have gained experience working alongside the Germans in English mines; alternatively his expertise may have been acquired through travel in Europe.

Sometime in early 1571 Medley was given the opportunity to demonstrate his alchemical skills to Sir Thomas Smith and the soldier and explorer Sir Humfrey Gilbert. Possibly Cecil introduced his relative to the pair, or perhaps Humfrey's brother Adrian, who had studied law at the Middle Temple at the same time as Medley, recognised his abilities. ${ }^{87}$ Adrian Gilbert's alchemical expertise was well known. He created "many admirable cures with his chemical medicines" and later worked closely with John Dee. ${ }^{88}$ Medley conducted a trial experiment of his alchemical method of transforming iron into copper by boiling copper ores in vitriol (sulphuric acid) and throwing in scrap iron to attract the copper by cementation. The process left Smith and Gilbert convinced. Smith's later comment that it could be "better otherwise to be done than as I gave instructions" suggests that he had some practical input on the process. ${ }^{89}$ Similar methods were outlined in Agricola's De Re Metallica (1556), of which Smith owned a copy. ${ }^{90}$ Medley, however, was

\footnotetext{
84 Ibid.

85 Ibid.

86 There is a curious reference to George Medley seizing control of an iron mine in Muchland, Cumbria in 1523-24. Whether George Medley had any actual experience with the iron mine that he may have passed on to his son his unclear, and I have been unable to uncover any more evidence about the incident. See Alfred Fell, The Early Iron Industry of Furness and District, London, 1968, pp. 52-57.

${ }^{87}$ Hopwood and Martin (eds.), Middle Temple Records, Volume 1, p. 144.

88 John Aubrey, Natural History of Wiltshire, London, 1847, p. 90.

89 Thomas Smith to William Medley, 20 May 1572, TNA, SP 70/146 f.56r.

${ }^{90}$ Strype, The Life of the Learned Sir Thomas Smith, p. 278.
} 
certainly the practical expert, who Smith insisted, "in the hand work is one of the best that I have seen". 91

According to both Medley and Smith the demonstrations were extremely successful. However, the high price of vitriol, a European import, made the process economically unfeasible. Medley, perhaps pushing his chemical skills a step too far, claimed that with the right ores, water and fuel he could create the vitriol needed to make his method economical. ${ }^{92}$ Seven weeks spent experimenting at Winchelsey, where plenty of wood was available for fuel, convinced Medley that while the creation of vitriol was indeed possible, a location with better 'earths' to make acid was needed. ${ }^{93}$

Cecil, Smith and Gilbert, now clearly convinced that Medley could make "nature ripe by art in the earthe", a common euphemism for alchemy, arranged for a full scale demonstration of Medley's alchemical process at the more suitable location of Poole, Dorset, where Lord Mountjoy had begun manufacturing copperas (ferrous sulphate) and alum (hydrated aluminium potassium sulphate). ${ }^{94}$ Gilbert and Cecil arranged a lease of one of Mountjoy's copperas 'houses' for Medley to work in. However, Medley discovered his name had been left off the lease of the Poole 'house', and refused to work until this was rectified, delaying the work until September. Medley then learned that their patent for the process had been stayed by the Queen, and halted the work once more, "for fear my Lorde Montjoy [would] get knowledge of the secrettes therof which to do he \& his fryndes go veray inderecttly aboutt". ${ }^{55}$ Without the protection of a patent for his copper process Medley began making copperas and alum in an attempt to cover his expenses. ${ }^{96}$ This would have appealed to Cecil's long term goal of limiting imports from Catholic Europe, for the Papacy monopolised the alum trade.

\footnotetext{
91 Thomas Smith to Cecil, 8 February 1572, TNA, SP70/146 f.20r.

92 Thomas Smith to Cecil and Leicester, 15 December 1574, BL, Lansdowne Vol. 19, No. 45.

93 Ibid.

94 William Medley to Cecil, 19 April 1572, TNA, SP12/86/14.

${ }^{95}$ Ibid.

${ }^{96}$ Ibid.
} 
Finally, in early December 1571, the Queen incorporated the investors in the alchemical scheme as the "Governor and Society of the New Art", with Sir Thomas Smith as the first governor. ${ }^{97}$ The patent granted the Society a monopoly on "a new and certain art to try out and make of iron very true and perfect copper". ${ }^{98}$ Anyone who breached the Society's monopoly would have their equipment confiscated and be imprisoned for one year. The patent makes clear the massive potential benefits of this alchemical process for the English economy, specifically that it

will be very profitable to Us our heirs and successors for the making of our ordnance and other munitions for the wars and for many other like uses, and also to all other the people and subjects of this our Realm of England ${ }^{99}$

The patent also specified that for the next five years the Society would have to give the royal treasury either $£ 100$, or a tenth of the copper and mercury they created.

Unfortunately for the project, that same month Smith, who amongst Medley's patrons had the best practical understanding of the alchemical methods involved, was assigned to head an embassy to France to pursue Elizabeth's marriage to the duc d'Anjou. With Cecil thoroughly engaged with affairs of state, Smith expected Gilbert to keep an eye on proceedings in Poole. Almost immediately Smith began to fret over the security of his significant investment in the scheme. He was justified in his fears. Gilbert time and again refused to make the trip to Poole to supervise the works, being “abused with Mr. Medeley's words and great promises that he can lead you by the nose whither he will, like a bufle[bull]". ${ }^{100}$

The situation at Poole quickly descended into an expensive farce. Lord Mountjoy claimed that Medley's stop-gap production of copperas and alum infringed his own monopoly over the creation of alum, while Smith worried about the practicality of Medley's

\footnotetext{
97 'Society of the New Art', Patent Rolls, 14 Eliz., pt. xii in Cecil Thomas Carr, Select Charters of Trading Companies, A.D. 1530-1707, New York, 1970, p. 21.

98 Ibid., pp. 21-22. The patent also gave them a monopoly on the transmutations of "antimony and lead [into] likewise true and perfect quicksilver". Strangely, there is no evidence that the Society ever tried to take advantage of this process.

${ }^{99}$ Ibid., p. 21.

100 Thomas Smith to Humfrey Gilbert, 8 February 1572, TNA, SP 70/146 f.16r.
} 
new process which "my Lord Burghley and my lord of Leicester do like". ${ }^{101}$ Meanwhile, Medley had realised that, despite assurances from Smith, the Society's patent omitted his name entirely. Medley characteristically assumed this was part of Gilbert's intrigues to deprive him of his process. Smith, trapped in Paris and distrustful of Medley's "negligence, riot and inconstancy", instructed Gilbert to travel to Poole and insinuate himself with Medley's assistant Cornelius Stephenson, “because you have no acquayntance there nor knowedge of the earths". ${ }^{102}$ Smith had come to suspect that

Mr. Medley will always be like himself, that is to mar the good gifts which God and his industry hath gotten to him by the evil ordering of himself ${ }^{103}$

Cecil attempted to prevent the disintegration of the project by promising Medley that he would try to convince the Queen to create a new patent, with Medley's name included. ${ }^{104}$ Medley wrote indignantly to Cecil that but for "the loose dealinge that I have suforyd" the endeavour would have already been worth over $£ 1,000 .^{105}$ Nevertheless, on his return from France in July 1572, Smith found the works at Poole abandoned, himself owing rent to Lady Mountjoy and wages to unpaid workmen, and that Medley had fled to Ireland. ${ }^{106}$

Historians have assumed that this fiasco deterred the nobility from costly ventures in industrial alchemy, or at least from investing in Medley's copper making process. However, by 1574 Medley had resurrected his enterprise on Parys Mountain, on the Isle of Anglesey, Wales. ${ }^{107}$ By boiling scrap iron in the mineral waters of Parys Mountain, rich in sulphate of copper after flowing through copper ores, Medley no longer required the expensive vitriol, making for a much more economical project. ${ }^{108}$ Cecil, and Leicester, along with Sir Francis Walsingham and Sir Henry Sidney, also devotees of alchemy, made

\footnotetext{
101 Ibid.

102 Thomas Smith to Humfrey Gilbert, 20 May 1572, SP70/146 f.56v.

103 Thomas Smith to Humfrey Gilbert, 10 April 1572, SP70/146 f.40r.

104 William Medley to Cecil, 19 April 1572, TNA, SP 12/86/14.

105 Ibid.

106 Smith to Cecil and Leicester, Lansdowne Vol. 19, No. 45.

107 Ibid.

108 John Henry Pepper, The Playbook of Metals: Including Personal Narratives of Visits to Coal, Lead, Copper, and Tin Mines, London, 1861, p. 274.
} 
the 250 mile journey to the Isle of Anglesey in 1574 to witness a trial of Medley's new technique. That Cecil, the Queen's chief minister, would undertake such a long journey at the age of fifty four, in the midst of other affairs, demonstrates the importance that he attributed to Medley and his alchemical project. Twenty-eight years later, Sir John Wynne, who witnessed the demonstration, remembered the trial as a complete success. Medley created copper of sufficient quality and quantity that "parte was sent to the [Lords] of the Counsell that were partners in the worke, parte to others of the nobilitie; and every gentleman of qualitie there presente had parte to carrie in his pockette". ${ }^{109}$

The immense success of this trial revived Cecil, Leicester and Smith's interest in the project. Smith, again on good terms with Medley, discussed with him the plans for the new works, and sent Cecil and Leicester a fresh offer from the alchemist. Smith claimed that Medley's new process would transmute every six tonnes of raw iron into five tonnes of pure copper, and also create as a by-product $£ 11$ worth of copperas and alum. ${ }^{110}$ A map in Cecil's papers (Image 3), which gives the distance from the north Anglesey coast to Medley's works, demonstrates the consideration given to the practicalities of the project. Medley demanded to be included in the new patent in exchange for his services. ${ }^{111}$ Smith agreed Medley's terms to be fair, claiming that "so it was ment at the first labouring for the patent". ${ }^{112}$ He would not, however, agree to Medley's renewed demands to have Gilbert ejected from the society. While Smith suggested that Cecil and Leicester send experts to assess the renewed works, he remained enthusiastic at the improved prospect of alchemical success. $^{113}$

\footnotetext{
109 Sir John Wynne to Lord Eure, 1602, in Walter Davies, General View of the Agriculture and Domestic Economy of North Wales, London, 1810, pp 484-486.

110 Smith to Cecil and Leicester, Lansdowne Vol. 19, No. 45.

111 Ibid.

112 Ibid.

113 Ibid.
} 


\section{Image 3:}

An Elizabethan Map of the north Anglesey coast, showing the distance to Medley's copper works, entitled 'A ploote of the woorkes and havens now fit for that purpose'

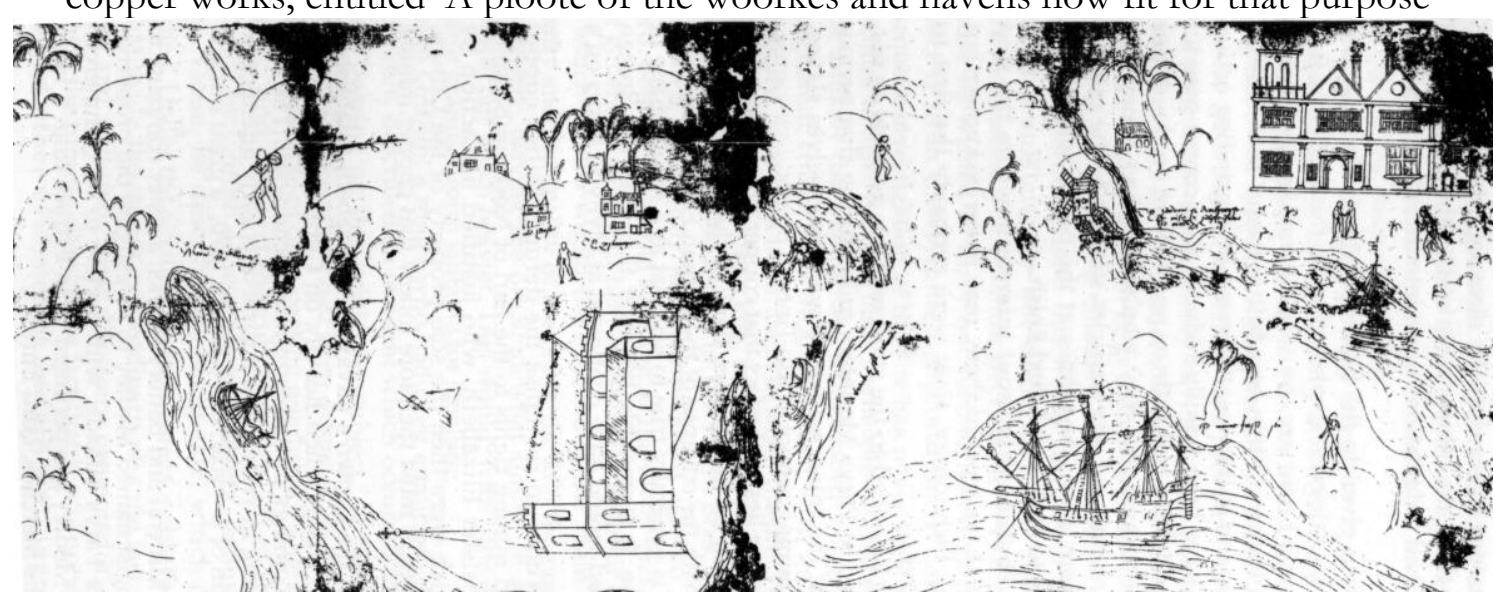

Source: Anon., undated, TNA, SP 45/36 MPF11.

The renewed project attracted a far wider range of patronage than Medley's earlier scheme. The copper samples dispatched to various members of the nobility created the most enthusiasm among Leicester's followers: his brother, the Earl of Warwick, Sir Henry Sidney, and Edward Dyer all investing heavily in the project. ${ }^{114}$ Others such as Leicester's friend Sir John Perrot, an influential courtier who had temporarily retired to his Welsh family home, certainly took an interest in the scheme. ${ }^{115}$ Leicester showed his personal support by appointing his retainer Sir John Hubaud to assess and supervise the works. ${ }^{116}$ Despite his sometimes rivalry with Leicester, Cecil had a good relationship with many of these men. Cecil particularly favoured Dyer, whose alchemical interests were already well known.

Cecil, prudent as ever and likely stung by the failure of the previous venture, chose William Humfrey, the assay master of the Royal Mint and Cecil's foremost metallurgical expert, as his assessor. ${ }^{117}$ While little is known of Humfrey's background or training, his position at the Mint was prestigious. ${ }^{118}$ Cecil had previously used Humfrey to assay the

\footnotetext{
114 Ibid; Thomas Smith and Leicester to Cecil, 7 March 1575, Lansdowne Vol. 19, No. 84.

115 The catalogue's misdating of this manuscript to 1579 has been the cause of a great deal of confusion amongst historians over the chronology of the project; Thomas Smith to Cecil, 8 March 1575, Lansdowne Vol. 29, No. 619.

116 Ibid.

117 William Humfrey to Cecil, 9 December 1574, BL, Lansdowne Vol. 18, No. 47.

118 Ash, Power, Knowledge and Expertise, pp. 34-35.
} 
yields of the Cumberland copper mines of the Company of Mines Royal, in which he was a major investor. Humfrey's pessimistic assessment of those mines had proved to be incorrect, forcing him to "certify your honor how small credit was to be given to the yield [of his assay]", and to admit his inferiority to the Company's German miners. ${ }^{119}$ The backwardness of English metallurgical knowledge, as illustrated by Humfrey's ignorance of continental metal working techniques, makes Medley's expertise all the more remarkable.

The results of Medley's process mystified Humfrey. Medley insisted, reported Humfrey, that using his secret technique a hundredweight of iron could be "transmuted by the water drawn from that earth" into a greater weight of copper. Humfrey, who had "neyther redd nor proved of any feasible knowledge that in anything coulde deliver a greater weight than himself and of a better substance then himself', skeptically declared the "matter is beyond the reason of all". ${ }^{120}$ The explanation for this mystery is that the copper precipitated by Medley's process, had a greater atomic weight than the dissolved scrap iron. ${ }^{121}$ Medley, as usual, did not help matters: he initially refused an inspection of the Parys Mountain works, fearing that Humfrey would "depryve him of his arte and laboures". ${ }^{122}$

Within a few weeks Cecil had calmed the alchemist's fears. Medley allowed Humfrey to monitor a demonstration. Humfrey remained at first sceptical about the possibility of multiplying metals and had "not therfor looked with creadit into such wourke". ${ }^{123}$ However, Medley's demonstration of the efficacy of his technique convinced Humfrey that "so honorable \& marveilouse a wourke ought to be gardid and garnerd to the end that by your great wysdome it might be ordered to unspeakable benyfit". ${ }^{124}$ Such

\footnotetext{
119 William Humfrey to Cecil, 23 May 1565, TNA, SP 12/36/58.

120 Lansdowne Vol. 18, f101-2.

${ }^{121}$ John Henry Pepper's The Playbook of Metals describes water being collected in ponds, scrap iron being cast into the pond, and "when the usual change of places occurs" it dissolves with copper precipitating "in a dark powdery mass". According to Pepper the process was "conducted with profit at the Paris Mountain Mine, in the island of Anglesea", when he was writing in 1846. See John Henry Pepper, The Playbook of Metals: Including Personal Narratives of Visits to Coal, Lead, Copper, and Tin Mines, London, 1861, p. 274.

122 Humfrey to Cecil, Lansdowne Vol. 18, No. 47.

123 William Humfrey to Cecil, 22 December 1574, BL, Lansdowne Vol. 18, No. 48.

124 Ibid.
} 
was the potential benefit for the Crown's balance sheet that it could not "but touch your honor being high L[ord] of the Treasure". ${ }^{25}$

His fears now totally assuaged, Cecil wholeheartedly put his influence behind the creation of a new patent for the Society, with Medley's name included. ${ }^{126}$ Cecil's draft of the new patent was conditional on Medley agreeing not to "multiply or make any gold or silver, contrary to the lawes of England". ${ }^{127}$ This condition reflects Cecil belief that Medley's process constituted a true form of alchemy, rather than any sort of conventional chemical technique. The clause also potentially allowed Medley to attempt transmutation into gold at a later stage, with the protection of a royal license.

The project also attracted the Queen's curiosity. Elizabeth placed a condition in the draft patent that, at her request "the society shall surrendere at the end of xxi yeres their whole interest into [her] highness hands". The condition allowed her the future profits of Medley's scheme, without immediately depleting the royal coffers. Cecil did not allow such an unfavorable condition to appear in the final patent, which Smith, now Secretary of State, in a remarkable example of conciliar deception, hurried past the Queen by candlelight. ${ }^{128}$ Smith assured Cecil that he would "make all the haste I can to have it passed the signet and the privy seal and so to the Great Seal". ${ }^{129}$ In return, Smith sought Cecil's assurance that he would keep the dilatory Medley on task. ${ }^{130}$

By 14 February 1575, with the final patent sealed, all seemed ready to proceed. ${ }^{131}$ Yet still Medley delayed, reluctant to travel to the new works until he received further money from the Society to pay his outstanding debts. With Medley procrastinating, Smith feared that others might usurp the project. In early March he complained that "my Lord Mountjoy hath gotten one of Mr. Medley's workmen to him" and that "diverse in the

\footnotetext{
125 Ibid.

126 Ibid.

127 Draft Second Patent, TNA, SP 15/13/122.

128 Smith to Cecil, 28 January 1575, BL, Harley MS. 6991/56.

${ }^{129}$ Ibid.

${ }^{130} \mathrm{Ibid}$.

${ }^{131}$ Joel Hurstfield (ed.), CPR: 1572-1575, London, 1939, p. 509.
} 
country, it is told me, knoweth the earth and the workings of it". ${ }^{132}$ Sir John Perrot had supposedly even gathered enough information on the process to write a discourse on its workings. ${ }^{133}$ Despite these pressures, sometime during 1575 Medley took the time to illustrate to Cecil their common education, penning 'A Brief Discourse of Rhetoric'. ${ }^{134}$

Smith turned to Cecil to compel his kinsman to make good his alchemical promises. ${ }^{135}$ He was confident that if Medley would devote himself to the project in earnest, they would know within a month "what proportion of charge is to the proportion of gain; and what hope we may conceive" of profits. ${ }^{136}$ Smith suggested that Cecil send either William Humfrey, or Humfrey Cole, the premier Elizabethan instrument maker, to assist Medley with the full scale works. ${ }^{137}$ However, after this we hear no more of the Anglesey works. Perhaps Medley delayed further, or perhaps the works were not economical or practical on an industrial scale. Those historians who credit the work with any legitimacy accept Sir John Wynne's assumption that as "the work would not quitte coste" it was abandoned by its patrons. ${ }^{138}$ Almost one hundred years later, Thomas Fuller argued that not enough patience was shown by those involved. As the project "was founded on rational probability (which I have cause to believe)", Fuller went so far as to suggest another trial for the project. ${ }^{139}$

The failure of a quick return for Leicester and his supporters, who had invested so heavily in the Anglesey works, spelled trouble for Medley. Having strongly supported the project, Leicester, fearful of losing face and not known for his patience with failure, moved against the troublesome alchemist. On 1 September 1576 the Sheriffs of London arrested

\footnotetext{
132 Smith to Cecil, Lansdowne Vol. 29, No. 61.

133 Ibid.

134 Medley, 'A Brief Discourse of Rhetoric', Cecil Papers, M485/6.

135 Thomas Smith to Cecil, 8 March 1575, BL, Lansdowne Vol. 29, No. 61.

136 Ibid.

${ }^{137}$ Ibid.

${ }^{138}$ Sir John Wynne to Lord Eure, 1602, in Walter Davies, General View of the Agriculture and Domestic Economy of North Wales, London, 1810, pp 484-486, William Rees, Industry before the Industrial Revolution, Vol. 2, Cardiff, 1968, p. 450.

139 Thomas Fuller, Worthies of Wales, London, 1662, p. 20.
} 
Medley "by commaundement mencyoned in a special warrant in wryttinge, under the handes of the right honourable Erles of Warwick and Leycester, for what cause we do not knowe". ${ }^{140}$ Cecil, however, had clearly not given up on the alchemical abilities of his kinsman, and requested Medley's bail in order to discuss the project with him further. The sheriffs replied that unfortunately this would not be possible due to "another specyall warrant signed by their honors to kepe the said Meadley more closer prisoner". ${ }^{141}$ This personal intervention by Leicester and Warwick challenges historians' assumptions that Medley was imprisoned for debt arising from the Society's operation. Cecil, not in a strong position, and likely not particularly pleased with Medley himself, decided not to antagonise the powerful Dudleys, and dropped the matter.

While Medley may have brought Leicester's fury on himself, evidence also suggests that his loss of patronage made him vulnerable to one of the campaigns of slander, forgery and intrigue which plagued Elizabethan politics. It may be that Medley's monopoly of alchemical patronage antagonised others who relied on alchemical promises. A letter from Lady Mary Sydney to Cecil exposes the identity of Medley's adversary. ${ }^{142}$ Lady Sydney, wife of Sir Henry Sydney and sister of Leicester and Warwick, had developed a friendship with Medley during her husband and brothers' involvement in the alchemical project. Strype presumed that Cecil ignored her opinion, "knowing better than she what kind of man he [Medley] was". ${ }^{143}$ Lady Sydney's letters, however, reveal that Medley's imprisonment resulted from the

contineulle mallisius persecutinge the same, by [John] Prestall, [Thomas] Curtes, and souche other, who wer but envyuys only to Med[ley] upon some old grudge amoungth them. ${ }^{144}$

John Prestall, a Catholic gentleman and conspirator who spent his life in and out of prison on treason charges, would have resented Medley's monopoly on alchemical patronage.

\footnotetext{
${ }^{140}$ Edward Osborne and Wolstan Dixie to Cecil, 12 September1576, Hatfield House, Cecil Papers, M485/42.

141 Ibid.

142 Mary Sidney to Cecil, 29 September 1576, BL, Lansdowne Vol. 23, No. 81.

${ }^{143}$ Strype, The Life of the Learned Sir Thomas Smith, p. 105.

144 Sidney to Cecil, Lansdowne Vol. 23, No. 81.
} 
Prestall himself repeatedly preyed on the desire of the nobility, including Cecil, for alchemical gold and medicine, promising to use his supposed alchemical abilities in exchange for his freedom. ${ }^{145}$ Prestall's alchemical promises to the ailing Earl of Pembroke had gained him a pardon for his part in the Pole conspiracy against Elizabeth in the 1560 s. $^{146}$

Prestall exploited Medley's weak position with Leicester, recasting Medley's delays and setbacks as malicious insults to Leicester and his supporters. Prestall ingratiated himself with Thomas Curtes, a servant of the Earl of Warwick and Medley's former friend. Curtes had lent Medley $£_{6} 60$, a significant amount, to repay Smith and Gilbert in $1571 .{ }^{147}$ Perhaps Medley had defaulted on this debt. Lady Sydney reported that Curtes had used his position with Warwick to press the keepers at the Counter prison to keep Medley in strict confinement and make sure "there were no letters or messages suffered to pass between him and me."148 Curtes' closeness to the Earl would also have assisted with discrediting Medley. After failing to convince Lady Sydney, the plotters "shewed no less yll meaning towards me ... [and brought] my name in with his", in order to reduce her credibility. According to Lady Sydney these men had subjected both Medley and herself to a campaign of slander, and so turned both Leicester and Warwick against the innocent Medley. Even with Medley in prison in September 1576, Prestall "cease[d] not still to invent matter against him". ${ }^{149}$

The letter book of Thomas Wotton, Medley's second cousin, gives us a glimpse into Prestall's methods of discrediting Medley. Wotton, a country gentleman uninterested in Court politics, received a perplexing letter from the Earl of Leicester on 2 October 1576, approximately a month after Medley's imprisonment. The powerful Privy Councillorclearly grateful for some new information on Medley's supposedly treacherous behaviour-

\footnotetext{
145 Parry, The Arch-Conjuror of England.

146 Ibid.

147 Medley to Cecil, SP12/86/14.

148 Sidney to Cecil, Lansdowne Vol. 23, No. 81.

149 Ibid.
} 
thanked Wotton for his letter detailing the "woordes and deedes spoken and done by Medleye". ${ }^{150}$ The problem was that Wotton had never written such a letter. Wotton responded that

if the Medleye mentioned in yor letter be not Henrye or Wylliam ... I neither know the man nor the matter; neyther was I (nor this that I have said standing trewe, coulde I be), the authoure of the letter that yowe wryt of. $^{151}$

While Wotton was pleased that the Earl has found the contents of the letter useful, he "wolde have wyshed the partie his selfe under his owne name to have taken the praise and thanncks of his owne doynge". ${ }^{152}$ Even Wotton, inexperienced with Court intrigue, recognised that "such brutes as tende to the infamie and suche accusations as tende to the peril of anye personne" should be "neither loved nor lightlie beleeved thone, nor used thother."153

As Leicester and Warwick's records are now largely lost, it is difficult to determine the extent of Prestall's attempts to discredit Medley. It is unlikely that he limited himself to just one forged letter. Prestall may have employed Vincent Murphyn, his brother in law and frequent accomplice, to orchestrate a campaign of forgery against Medley, as he had against John Dee in $1563 .{ }^{154}$

In October 1578, while Medley still languished in prison, fear of occult magic wracked the Court, eventually destroying Prestall's credibility. ${ }^{155}$ The discovery of three wax images, one bearing the name 'Elizabeth', under a dung heap in Islington, amplified the concerns about conspiracies of the always paranoid Privy Council into full blown panic. ${ }^{156}$ Presuming the images were a magical attack upon the Queen—the premise being that as the wax melted the Queen would grow sick and die-the Councillors looked to Dee to

150 Thomas Wotton to the Earl of Leicester, 2 October 1576, in G. Eland (ed.) Thomas Wotton's Letter-Book: 1574-1586, London, 1960, p. 12.

151 Ibid.

152 Ibid.

153 Ibid.

154 Parry, The Arch-Conjuror of England.

155 Medley remained in confinement until at least October 1577, as he still languished in the Counter when his servant, Anthony Egleston, assaulted a Florentine gentleman Piero Capony. It is unclear what motivated the assault or whether it was related to any of Medley's previous problems. See APC Vol. 10 1577-78, p. 393.

156 Parry, The Arch-Conjuror of England. 
perform counter magic and to divine the identity of the perpetrators. ${ }^{157}$ Seizing the opportunity to vilify his own long time enemy, Dee implicated Prestall in creating the images as part of a Catholic plot. ${ }^{158}$ In fact, the images had been created by Thomas Elkes, whose ritual magic was aimed at the husband of an entirely different Elizabeth. ${ }^{159}$ Nevertheless, Prestall and his associates were arrested and under torture confessed their roles in the imaginary conspiracy. ${ }^{160}$ With Prestall imprisoned for treason, and his allegations against Medley discredited, Medley regained his freedom.

Medley's re-established reputation, previously overlooked by historians, allowed him to survive another alchemical scandal in August 1580. Cecil suspected that Richard Stanihurst, an Irish Catholic alchemist, was creating alchemical gold to fund Catholic plans for rebellion in Ireland. During a search of Stanihurst's house, Robert Beale, clerk of the Privy Council and one of Cecil's trusted informants, found that Medley and Stanihurst had been exchanging letters on alchemical matters. ${ }^{161}$ Stanihurst clearly shared an interest in the same elements of alchemy as Medley. His Toque De Alchimia (1593), dedicated to the Spanish King Phillip II, would profess his expertise in both alchemical medicine and the alchemical transformation of copper. ${ }^{162}$ Stanihurst claimed to have witnessed the transmutation of copper into silver in London in 1578, and although Medley's role remains unclear, it was certainly within his field of expertise. ${ }^{163}$ So convincing was the demonstration that, as Stanihurst recalled, it "convinced me of what I had until then thought impossible and led me to apply myself to the practice of this secret science". ${ }^{164}$ After confronting Medley with the evidence of collusion, Cecil accepted his assurances that while he had been discussing "mineral matters" with Stanihurst, "he denieth there was any

\footnotetext{
157 Ibid.

158 Ibid.

159 Ibid.

160 Ibid.

${ }^{161}$ Robert Beale to Cecil, 28 August 1580, TNA, SP 12/141/43.

162 Richard Stanihurst, 'Toque de Alchimia', BNM MS. 2058, trans. in David C. Goodman, Power and Penury:

Government, Technology and Science in Philip II's Spain, Cambridge, 2002, p. 43.

163 Ibid.

164 Ibid.
} 
intention to have medled with any coining or forging". ${ }^{165}$ Certainly by this time Medley had restored his standing with the Lord Treasurer.

Cecil's influence enabled Medley to become an important member of the local gentry in Ely, Cambridgeshire, where he had inherited land from his father. ${ }^{166}$ Medley's Catholic critics claimed that he received through Cecil's "favour and patronage some kind of civil preferment", becoming a justice of gaol delivery (an important type of magistrate). ${ }^{167}$ By December 1580, George Shirley, attempting to purchase a wardship from Cecil, considered Medley important enough to be bribed $£ 3$, the same as one of Cecil's secretaries, if he would further his case. ${ }^{168}$ Medley's re-established social status allowed him to marry a wealthy widow, Anne Wren, the daughter of Sir Robert Payton, a prominent local landowner, in $1582 .{ }^{169}$ This marriage, along with a modest bequest in his brother's will in 1585, seems to have alleviated Medley's financial situation for a time and in turn reduced his need for alchemical schemes. ${ }^{170}$ Medley demonstrated his renewed prosperity and favour with the generous bequest of twenty acres of land to the nearby parish of Tydd St. Mary in $1588 .^{171}$

Throughout Medley's career as a magistrate in Ely he received a number of rewards from his patron. Cecil, as always, valued clients with alchemical ability. Indeed, despite his local offices, Medley claimed to have been in "daily attendance" on the Lord Treasurer, possibly as a practitioner of alchemical medicine. ${ }^{172}$ For his services Medley "received divers favours", including Crown leases. ${ }^{173}$ In June 1588, Cecil wrote to Lord North, Lord Lieutenant of Cambridgeshire, and ordered him to spare Medley from his previous

\footnotetext{
165 Beale to Cecil, SP 12/141/43.

166 'Will of George Medley, PROB 11/46; Louise J. Wilkinson (ed.), CPR (1589-1590), C 66-1337-1361, London, 2004, p. 242.

167 William Weston, Philip Caraman (ed.), William Weston: The Autobiography of an Elizabethan, Philip Caraman (trans.), London, 1955, p. 192.

168 Joel Hurstfield, The Queen's Wards: Wardship and Marriage under Eilzabeth I, London, 1973, pp. 265-266.

169 Robert Edmond Chester Waters, Genealogical Memoirs of the Extinct Family of Chester of Chicheley: their Ancestors and Descendants, London, 1878, pp. 211-212.

170 'Will of Henry Medley of Tilty, Essex', TNA, PROB 11/68, proved 8 May 1585.

171 Anon., Abstract of the Returns of Charitable Donations for the Benefit of Poor Persons, Made by the Ministers and

Churchwardens of the Several Parishes and Townships in England and Wales, London, 1816, p. 672.

172 Roberts (ed.), CMS, Vol.8, p. 421.

${ }^{173}$ Ibid.; Christine Leighton (ed.), CPR, Part I to Part X: C 66/1395-1404, London, 2000, p. 75.
} 
commitment to act as the captain of the men of Ely. Medley again evidently enjoyed Cecil's special protection as Lord North quickly consented. ${ }^{174}$

In October 1588 Cecil pressured the Dean of Ely to renew Medley's lucrative lease on Wentworth manor "for three lives, wherof he hathe two in being". ${ }^{175}$ These were not three successive lives or generations — rather Medley would be able to choose three living people and the lease would expire upon the death of the last person. The Dean of Ely replied that although Medley was "your Lords servant", he had already taken advantage of his position with Cecil four or five years previously, extending his other leases belonging to the church to three lives. So disadvantageous had the arrangement proved for the church that they altered their charter, prohibiting leases longer than twenty-one years. The Dean and Prebendaries of Ely pleaded with Cecil that, as their patron, he would not require them to break with this limit. ${ }^{176}$ When John Strype described the incident, the eighteenth century historian acknowledged the reputation of Medley, whom he had left imprisoned for debt in his earlier book, as a "famous chymist, and retainer to that lord[Cecil]". ${ }^{177}$

The strongest demonstration of Cecil's continued favour towards Medley came in May 1594, when Medley became keeper of the Catholic recusant Priests and Jesuits in Wisbech Castle, ahead of the nominees of Lord North. ${ }^{178}$ The exact circumstances of his appointment are not clear, as the Privy Council records for that year have been lost. According to William Weston, an imprisoned Catholic at Wisbech, their first keeper, Thomas Grey, was

removed from the scene by a most ghastly death, and in his place we had another man who was anxious to be considered a gentleman. He claimed to have served for a time in the household of the Treasurer, William Cecil,

\footnotetext{
174 Roger North to Cecil, 25 June 1588, BL, Lansdowne Vol. 57, No. 43.

175 The Dean and Prebendaries of Ely to Cecil, 29 October 1588, BL, Lansdowne Vol. 58, No. 4.

176 Ibid.

177 Strype, Annals of the Reformation, Vol. 3, p. 72.

178 William Medley to Robert Cecil, 8 May 1594, Hatfield House, The Cecil Papers, M485/6; The Privy Council to Roger North, 26 October 1592 in John Roche Dasent (ed.), APC, Volume 23: A.D. 1592, London, 1901, p. 263.
} 
and to have received through his favour and patronage [the position of] magistrate or keeper of the public peace. ${ }^{179}$

This concurs with his fellow prisoner Christopher Bagshaw's account, in which Medley claims the authority to deal with ecclesiastical disputes as

I[Medley] am a justice of peace, qualifyed to take notice of such crimes ... Why (sayd maister Medlye) what crymes are those so horrible, that the Queenes authority cannot reach to take knowledge of? ${ }^{180}$

Cecil's support for Medley and his alchemical abilities had stood the new keeper in good stead, as "he had of his side ... men who favoured, yes, even encouraged his pretensions". ${ }^{181}$ Medley's confidence in "the authority which he was used to exercise over layfolk" further confirms his status as one of Cecil's foremost servants in Cambridgeshire. ${ }^{182}$

While Weston assessed Medley's new position as “an office that carried with it large annual revenues and emoluments with a minimum of work", it proved anything but. ${ }^{183}$ A dispute over the Jesuit administration of the Catholic mission in England strained relations between the prisoners. Moreover, starved and sickly, they were attempting to escape in increasing numbers. ${ }^{184}$ Medley's attempts to simultaneously keep control of his prisoners and keep the Privy Council contented met with mixed success. In late 1595 the Council commended Medley's "good zeale to the service of her majesty" in his handling of "the seditious speeches of one Edward Haule[Hall], a servant of yours." ${ }^{185}$ Medley's other servants accused Hall of implying that the coming year would bring some relief to the imprisoned Catholics. ${ }^{186}$

As the aging William Cecil's influence and health began to wane, Medley attempted to cultivate the patronage of his younger son Robert. In 1594 Medley attempted to impress

\footnotetext{
179 Weston, Caraman (ed.), William Weston, p. 192.

${ }^{180}$ Christopher Bagshaw, 'A True Relation of the Faction Begun at Wisbech' in Thomas Law(ed.), A Historical Sketch of the Conflicts Between Jesuits and Seculars in the Reign of Queen Elizabeth, London, 1889, p. 23.

181 Weston, Caraman (ed.), William Weston, p. 192.

182 Ibid.

183 Ibid.

184 William Medley to Sir Robert Cecil, 1 March 1595, in R. A. Roberts (ed.), CMS, Vol. 6: 1596, London, 1895 , p. 77.

185 The Privy Council to William Medley, 26 December 1595, in John Roche Dasent (ed.), APC, Volume 25: A.D. 1595-1596, London, 1901, p. 131.

186 William Medley's examination of John Foxly, 21 December 1595, TNA, SP 12/255/14.
} 
Robert Cecil with his alchemical abilities, sending him “a poore present as either [Medley's] weake race affordes or the foggie climate gives life unto" as a demonstration of his “carefull endeavours". ${ }^{187}$ Medley's wife Anne died in 1595, and in 1597 Medley turned to Robert Cecil to write a letter encouraging Jane Boughton, a wealthy widow, to marry him. ${ }^{188}$ However, Robert Cecil was a very different man from his father. Much more sceptical about alchemy and alchemists, Medley's particular expertise would not have held so great an appeal.

The Privy Council became increasingly dissatisfied with Medley's management of Wisbech prison and its recusant prisoners. The number of escapes had increased, and a number of the prisoners were so ill they had to be removed. ${ }^{189}$ Sir Nicholas Bacon, William Cecil's nephew-in-law and constable of Wisbech Castle, pressured Medley over issues surrounding governance and lodgings. ${ }^{190}$ Medley consented in late 1597 to Bacon's retainer William Brewster becoming joint keeper of the recusants, provided that the Cecils, "without whom I yield to nothing", approved of the measure. ${ }^{191}$ Medley's grief over "that most lamentable dispersion" of Cecil's followers after the Lord Treasurer's death in August 1598 would have been genuine. ${ }^{192}$ He realised just how tied his fortunes were to that of his great patron. Medley cannot have sufficiently ingratiated himself with Robert Cecil, as by October 1598 Brewster was the sole keeper at Wisbech. ${ }^{193}$ Robert Cecil seems to have ignored Medley's further pleas for employment. ${ }^{194}$ Finally in late 1600 Medley was once

\footnotetext{
187 William Medley to Robert Cecil, 8 May 1594, Hatfield House, The Cecil Papers, M485/6.

188 William Medley to Robert Cecil, 17 February 1597, TNA, SP12/267/42; William Medley to Sir Robert Cecil, 20 May 1597 in R. A. Roberts (ed.), CMS. Vol. 7: 1597, London, 1899, p 206; Clifford A. Thurley and Dorothea Thurley (eds.), Index of the Probate Records of the Court of the Archdeacon of Ely 1513-1857, London, 1976, p. 127.

189 The Privy Council to Sir John Higham, 20 September 1597, Dasent (ed.), APC, Volume 28: 1597, London, 1904, p. 6.

190 William Medley to Robert Cecil, 1 August 1597 in Roberts (ed.), CMS, Vol. 7, p. 330.

191 Ibid.

192 William Medley to Robert Cecil, 3 November 1598 in Roberts (ed.), CMS, Vol. 8, p. 421.

193 Privy Council to William Brewster in 15 October 1598, John Roche Dasent (ed.), APC, Volume 29: A.D. 1598-1599, London, 1905, p. 228.

194 William Medley to Robert Cecil, 12 December 1598 in Roberts (ed.), CMS, Vol. 8, p. 492.
} 
again imprisoned, this time almost certainly for debt, although he once again blamed unknown adversaries for his undoing. ${ }^{195}$

William Medley, still concealed from the historiography by the condescension of scientific progress, provides the most important example of the practical application of alchemical knowledge within the English gentry. Cecil as in other instances throughout his life, showed no scepticism about the legitimacy of this knowledge, nor its practical possibilities. In fact Cecil maintained faith in its potential long after others had despaired of Medley and his process.

The very fact that the Society of the New Art gained such widespread patronage reveals the prevalence of belief in the possibility of alchemical transmutation in Elizabethan England. Not only did the country's leading statesmen such as Cecil, Leicester and Smith condone Medley's activities, they backed him financially with their own money. Medley, unlike many practical alchemists in the Elizabethan period, was not a foreigner or a stranger to the Elizabethan nobility. He came from a very well connected Protestant gentry family, and formed part of what G. R. Morrison describes as Cecil's "greater kin, related to Burghley by virtue of his marriage to Mildred Cooke". ${ }^{196}$ Although he did not attend university, he had extensive legal training from the Middle Temple and his 'Discourse of Rhetoric' exhibits the kind of classical education that would have identified him as being part of the upper strata of society.

Unlike Richard Eden, Medley never showed a philosophical interest in alchemy, concerning himself with its practical applications, although his education would have equipped him with a philosophical justification for his process. In this way Medley was very much the English equivalent of the central European practical alchemists examined by Tara Nummedal. These alchemists, according to Nummedal, appealed to elite patrons

195 William Medley to Robert Cecil, 15 November 1600, R. A. Roberts (ed.), CMS. Vol. 10: 1600, London, 1904, p. 385.

${ }^{196}$ G. R. Morrison, 'The Land, Family, and Domestic Following of William Cecil, Lord Burghley c. (1550-

1598)', Unpublished Phd Thesis, University of Oxford, 1990. p. 94. 
because their appeals aimed "at understanding how to manipulate nature in order to make it more prolific". ${ }^{197}$ Medley, like his German counterparts, isolated his alchemical process from its theoretical background, presenting it simply as a process based on an understanding of nature assumed by all involved. Likewise Cecil's patronage of Medley can be seen as analogous to the central European princes who understood alchemy to be "a solution to the financial and mining crises afflicting their territories". ${ }^{198}$

Bred up under Cecil, Medley anticipated that the Lord Treasurer's alchemical view of nature and desire to improve England's economic security would induce him to back his process. When threatened by controversy and intrigue, Medley would repeatedly turn to his relative, with generally successful results. In the same way, Medley's rapid demise after Cecil's death in 1598 had nothing to do with his alchemical reputation and everything to do with his dependence on his relative for the maintenance of his position and status.

It is difficult to establish exactly how Medley served Cecil during his later life, but it seems likely that his chemical proficiency encouraged Cecil's continued patronage. Morrison argues that while Cecil received a variety of requests for favour from his 'greater kin', “Burghley's political practicality precluded his advancing the career of anyone who claimed as his primary qualification the fact that he was a kinsman". ${ }^{199}$ Medley needed to prove useful to the Lord Treasurer in order to justify his continued "favour and patronage" ${ }^{200}$ No doubt he did so to some extent as a qualified and practising magistrate, but his previous service and hints of a continued chemical interest suggest he also provided alchemical expertise.

The Frobisher voyages and the Society of the New Art were not the only attempts to apply alchemical knowledge for the benefit of economic projects. There is some evidence that the Company of Mines Royal, a major copper mining project in which Cecil

\footnotetext{
197 Nummedal, 'Practical Alchemy and Commercial Exchange', p. 211.

198 Ibid., p. 210.

${ }^{199}$ Ibid., p. 97.

200 Weston, Caraman (ed.), William Weston, p. 192.
} 
was a key investor, attempted to utilise alchemical techniques. ${ }^{201}$ In the years prior to the Company's incorporation, the supervisor of the project, Thomas Thurland, corresponded frequently with Richard Eden regarding his alchemical experiments and the arrangement of the Company's royal patent. ${ }^{202}$ It is clear that Thurland considered Eden's alchemical knowledge practically useful. Likewise, in 1583 John Dee and the alchemist Adrian Gilbert leased from the Company the right to search for gold, silver, copper, and quicksilver in the Devonshire mines for fifteen years. ${ }^{203}$ Whilst the project never went ahead due to Dee's travels in Europe, Cecil certainly saw Dee and Gilbert's largely theoretical alchemical knowledge as applicable to practical endeavours.

Cecil, through his patronage of industrial alchemical projects, attempted to aid the English economy by implementing alchemical concepts on a practical level. Ignored by Heal and Holmes, the projects examined in this chapter reveal that Cecil's attitude towards alchemy mirrored that of the German princes examined by Nummedal. ${ }^{204}$ Both the assays of the Frobisher ore and the Society of the New Art relied on supposedly alchemical knowledge and techniques. Given Cecil's understanding of the manner in which metals generated, utilising alchemical techniques to extract gold from the Frobisher ore would have seemed imminently sensible, and certainly did not dissuade Cecil from taking a leading role in the project. Likewise, Cecil invested a significant amount of his own money in the Society of the New Art, based entirely on the understanding that William Medley was performing alchemy. The role of alchemical experts in both of these industrial projects supports Nummedal's contention that sixteenth century patrons saw alchemical expertise as particularly relevant to practical ventures. ${ }^{205}$ Moreover, it demonstrates the fallacy of the historical distinction between alchemy and utilitarian patronage.

\footnotetext{
201 Ash, Power, Knowledge and Expertise, pp. 19-23

202 Ibid; Eden to Cecil, Lansdowne, Vol 101, No. 5.

203 Parry, The Arch-Conjuror, chapter 43.

${ }^{204}$ Nummedal, Alchemy and Authority.

205 Tara Nummedal, 'Practical Alchemy and Commercial Exchange', p. 210.
} 


\section{Conclusion}

Stephen Alford has recognised that "So much of what Burghley knew is gone, either emptied of meaning or changed beyond all recognition". ${ }^{2}$ The implications of this statement are broader than Alford seems to have appreciated. Cecil's patronage of alchemy suggests that historians have fundamentally misunderstood his character. Many of the examples examined in this thesis are well documented in the primary sources, yet have been largely ignored by the existing scholarship. Historians have disregarded them, not simply due to a lack of interest in alchemy, but because Cecil's actions did not fit with the character they had constructed for him. The association of alchemy with esoteric spiritualism, witchcraft and necromancy is in part responsible for blinding many historians to the true influence of alchemical concepts in the Elizabethan Court. Lawrence Principe and William Newman have argued that historians "who do not utilize primary sources are particularly liable to acquiesce to the esoteric view [of alchemy]."2 To Cecil alchemy was not a dark, arcane art, rather the legitimate attempt of man to manipulate the unity of nature.

This thesis has investigated William Cecil's enduring interest in alchemical patronage throughout his career. Four key forms of Cecil's alchemical patronage have been analysed, using a number of case studies: philosophical patronage; medical patronage; financial patronage; and economic patronage.

In order to establish the position of alchemy within Cecil's worldview, Chapter one examined both the diversity of alchemical belief in the sixteenth century, and the environment within which Cecil was educated. What has emerged is that alchemical ideas were not only complementary to, but an essential element of, Cecil's Aristotelian

\footnotetext{
1 Alford, Burghley, p. 343.

${ }^{2}$ Principe and Newman, 'Some Problems with the Historiography of Alchemy', p. 397.
} 
understanding of nature. John Dee, Richard Eden and Francis Thynne appealed to this understanding, seeking Cecil's patronage principally through demonstrations of alchemical and occult theory. Dee had a decidedly mixed relationship with Cecil, as his actions during the reign of Queen Mary made him religiously unreliable. Eden, however, shared the same circle of friends from Cambridge and had been Cecil's secretary. Throughout their correspondence Eden made particular reference to their mutual interest in alchemy, fostered by their common education. Thynne, well known to Cecil through personal and Court connections, used demonstrations of overtly occult knowledge to gain his freedom from prison. These examples demonstrate that Cecil's interest in alchemy lay, not only in its practical implications, but also its philosophical basis.

Cecil suffered from frequent and severe attacks of gout and was thus one of England's premier medical patrons. He lived at a time of radical change in medical practice, as Paracelsian theory, steeped in alchemical concepts, began to challenge traditional Galenic medical practice. The evidence examined in Chapter two suggests that Cecil was at the forefront of this change. He patronised a broad range of medical practitioners, from immigrants condemned by the College of Physicians, to doctors highly esteemed within the medical establishment. The common thread between these practitioners was their acceptance of the validity of chemical medicines. Appeals to Cecil offering chemical cures for his ailments suggest his predilection was well known. The alchemists Humfrey Lock and Samuel Norton judged alchemical medical theory of sufficient concern to Cecil to write him lengthy treatises on the matter.

Despite Cecil's fascination with alchemical philosophy, he never devoted significant resources to the kinds of theoretical and spiritual alchemy popular in some European courts, such as that of Emperor Rudolf II. Unlike the Catholic position in the Holy Roman Empire, the situation of Elizabeth's Protestant regime was decidedly uneasy. Rather than displays of ostentatious knowledge, the Elizabethan government favoured utilitarian alchemical patronage. Cecil's belief in the possibility of alchemical transmutation 
led him to back a number of alchemical schemes designed to relieve strained Crown finances. When - amidst the financial crises of the 1560s-Cornelius de Lannoy wrote to Cecil promising alchemical riches, Cecil arranged for the alchemist to travel to England, obtained his alchemical equipment, and kept himself informed of every stage of the project. When de Lannoy attempted to flee the country, rather than assume him to be a fraud and abandon the project, Cecil instead assumed that the alchemist had succeeded in his aims. Once he had de Lannoy securely confined, Cecil again provided the expensive equipment needed for transmutation.

Much later, in the 1580s and 1590s when war with Spain stretched royal resources to breaking point, Cecil again sought an alchemical solution. He went to enormous lengths to bring the alchemist Edward Kelley back to England. Not only did he and the Queen enter into correspondence with Kelley, offering rich rewards for his alchemical skills, Cecil also put the extensive resources of his European intelligence network behind an effort to unearth Kelley's secret. Belief in the alchemist's potential died hard, and Cecil's attempts to return Kelley to England continued long after the alchemist's imprisonment. In the aftermath of this failure, Cecil played a central role in the Elizabethan Court's attempts to profit from the alchemical equipment of Clement Oldfield and Roloff Peterson, first coordinating attempts to evaluate the equipment's legitimacy, then attempts to sell it in Europe.

To Cecil, alchemy also had the potential to aid in England's industrial growth. Unlike his patronage of attempts to transmute base metals into gold for the Crown Treasury, these projects played a coherent part in Cecil's economic policy. The bubble of speculation surrounding Martin Frobisher's ore in 1577 centred around two alchemists, Giovanni Baptista Agnello and Burchard Kranich. Cecil, one of the key investors and administrators of the project, knew of both men's alchemical backgrounds, having been 
promised "an ounce or so of powder of transmutation" from Agnello a decade earlier. ${ }^{3}$ Despite, or perhaps because of this, Cecil believed in the potential of the Frobisher project to provide England with a source of precious metals comparable to that of the Spanish in South America.

Cecil's key role in funding and administering the Society of the New Art provides an overlooked example of his patronage of large scale industrial alchemical projects. By financing and supporting what he thought to be an alchemical method of transmuting iron into copper, Cecil sought to increase England's economic independence from Catholic Europe. Furthermore, the alchemist involved, William Medley, was also Cecil's relative, brought up in his household. Whilst Cecil may have used experts to verify the viability of the project, he maintained a belief and interest in Medley's methods, long after the other investors had grown angry with his delays and excuses. Although Cecil allowed Medley to be incarcerated for his failure, the imprisonment was a consequence of the intrigues of another alchemist, John Prestall. Once Prestall had been discredited, Medley was released and became one of Cecil's key clients in Cambridgeshire.

Time and time again Cecil was at the centre of the Elizabethan regime's alchemical projects. Alchemical hopefuls targeted Cecil with promises and plans, and rather than ignoring them, he consistently considered their potential. Although not everyone who sought Cecil's alchemical patronage did so with honest intent, it would be a mistake to assume they were all charlatans. In some cases they were utilising legitimate, if misunderstood, chemical processes, whilst even those alchemists professing the ability to transmute metals did so in the assumption that such a process was possible.

This thesis does not argue that Cecil was the only member of the Elizabethan Court fascinated by the potential of alchemy. In fact, through examining Cecil's belief in alchemy, it has become clear that many at the Court shared his view. The Earl of Leicester involved himself in the de Lannoy episode and was a major backer of both the Society of

${ }^{3}$ The Vidame de Chartres to Cecil, in Crosby (ed.), CSPF 1569-71, p. 142. 
the New Art and the Frobisher voyages. Queen Elizabeth's involvement in these schemes is also apparent. Going as far as visiting de Lannoy in Somerset House and writing a number of letters to Edward Kelley, her fascination with alchemy is evident. However, by the end of Elizabeth's reign, the interests and priorities of the Court seem to have shifted. Late Elizabethan courtiers were often more religiously and philosophically conservativeand hence had further reservations about the authenticity of alchemical claims.

More generally, this thesis has contributed to the broader historiography of patronage in early modern Europe. While Francis Dawbarn and Stephen Pumfrey's hypothesis of Cecil as a utilitarian patron of science may largely be valid, alchemy clearly held a place in this patronage that they did not acknowledge. Cecil saw no contradiction in employing alchemists to support the development of the English economy, to aid Crown finances, or even to treat his debilitating gout. This thesis has demonstrated Cecil's alchemical patronage to parallel that of the Protestant German princes examined by Bruce Moran and Tara Nummedal. Whilst their patronage of alchemy usually served a practical purpose, this did not imply

that such princes were any less intellectually committed to the reality of spiritual forces and the truth of a vitalist world view. ${ }^{4}$

Like the German Landgraf Moritz of Hesse-Kassel, Cecil believed that "in the occult arts could be found technical solutions to political problems." ${ }^{5}$ Whilst these solutions took a number of forms, from medical tinctures to transmutation, they were based on the same understanding of nature that justified ostentatious occult patronage by rulers such as Emperor Rudolf II.

Further research is required to reveal the full importance of alchemy within the Elizabethan Court. Whether Cecil's belief in, and patronage of, astrology reinforced his

\footnotetext{
${ }^{4}$ Moran, The Alchemical World, p. 174.
}

${ }^{5}$ Ibid. 
conviction regarding the reality of alchemical transmutation requires further study. Thorough examination of alchemical themes and symbolism within Elizabethan art and theatre would also be informative. From the spiritual alchemy of William Shakespeare's Prospero, to Ben Jonson's alchemical charlatans Subtle and Face, alchemy was a popular theme amongst early modern dramatists. The extent to which these themes either reflected or satirised elite attitudes remains largely unexamined. Also, this thesis has focussed on the English elite in the Elizabethan period, and there is ample further scope for research on alchemical belief both elsewhere in sixteenth century England and at other levels of society.

Alchemical patronage in Elizabethan England depended, as it did in France and the Holy Roman Empire, on a unified and metaphoric understanding of nature. This thesis has demonstrated that Cecil shared this understanding, and therefore his attempts to utilise alchemy were part of a rational and cohesive system of patronage. Although on a personal level Cecil maintained an interest in alchemical theory, as Queen Elizabeth's chief government minister his patronage of alchemy was selective, moderated by a desire to strengthen and stabilise the realm and increase its wealth. Those alchemists who could demonstrate a significant potential value in their work, benefited from this desire. Throughout his career Cecil therefore continued to view alchemy as a legitimate solution to both personal and national maladies. 


\section{Bibliography}

\section{Primary Sources}

\section{Calendars, Catalogues and Indices}

Anon., Journal of the House of Lords: Volume 1: 1509-1577, London, 1802.

Crosby, Allan James (ed.), Calendar of State Papers, Foreign Series, of the Reign of Elizabeth 156971, London, 1874.

Dasent, John Roche (ed.), Acts of the Privy Council of England, Volume 4: A.D. 1552-1554, London, 1892.

—. Acts of the Privy Council of England, Volume 10: A.D. 1577-1578, London, 1895.

—, Acts of the Privy Council of England, Volume 16: A.D. 1588, London, 1897.

—. Acts of the Privy Council of England, Volume 20: A.D. 1590-1591, London, 1900.

—, Acts of the Privy Council of England, Volume 23: A.D. 1592, London, 1901.

—, Acts of the Privy Council of England, Volume 25: A.D. 1595-1596, London, 1901.

—, Acts of the Privy Council of England, Volume 28: A.D. 1597, London, 1904.

—, Acts of the Privy Council of England, Volume 29: A.D. 1598-1599, London, 1905.

Ellis, H., and F. Douce (eds.), A Catalogue of the Lansdowne Manuscripts in the British Museum: With Indexes of Persons, Places and Matters, London, 1819.

Historical Manuscripts Commission, Third Report of the Royal Commission on Historical Manuscripts, Appendix, London, 1872.

Hopwood, Charles Henry, and Charles Trice Martin (eds.), Middle Temple Records, Volume 1, London, 1904.

Hurstfield, Joel (ed.), Calendar of the Patent Rolls Preserved in the Public Record Office: Elizabeth: 1572-1575, London, 1939.

Leighton, Christine (ed.), Calendar of Patent Rolls 35 Elizabeth I,Part I to Part X: C 66/13951404, London, 2000.

Lemon, R. (ed.), Calendar of State Papers, Domestic Series, of the Reigns of Edward VI, Mary, Elizabeth, 1547-1580, London, 1856.

Maxwell-Lyte, Henry Churchill (ed.), Calendar of the Patent Rolls Philip and Mary, Volume 1: 1553-1554, London, 1937.

Neal, Simon R, Christine Leighton (eds.), Calendar of Patent Rolls 36 Elizabeth I (1593-1594), London, 2005. 
- Calendar of Patent Rolls 37 Elizabeth I (1594-1595), London, 2006.

Public Records Office of the United Kingdom, Calendar of Patent Rolls Vol. 6 Elizabeth I (1572-1575), London, 1939.

Roberts, R. A. (ed.), Calendar of the Manuscripts of the Most Hon. The Marquis of Salisbury, Preserved at Hatfield House Hertfordshire. Vol. 4: 1590-1594, London, 1892.

- Calendar of the Manuscripts of the Most Hon. The Marquis of Salisbury, Preserved at Hatfield House Herffordshire. Vol. 5: 1594-1595, London, 1894.

- Calendar of the Manuscripts of the Most Hon. The Marquis of Salisbury, Preserved at Hatfield House Hertfordshire. Vol. 6: 1596, London, 1895.

- Calendar of the Manuscripts of the Most Hon. The Marquis of Salisbury, Preserved at Hatfield House Herffordshire. Vol. 7: 1597, London, 1899.

- Calendar of the Manuscripts of the Most Hon. The Marquis of Salisbury, Preserved at Hatfield House Hertfordshire. Vol. 8: 1598, London, 1899.

- Calendar of the Manuscripts of the Most Hon. The Marquis of Salisbury, Preserved at Hatfield House Herffordshire. Vol. 10: 1600, London, 1904.

Salisbury, K. G., (ed.), Calendar of the Manuscripts of the Most Hon. The Marquis of Salisbury, Preserved at Hatfield House Hertfordshire. Vol. 13: 12C-1597, London, 1915.

Scargill Bird, S. R. (ed.), Calendar of the Manuscripts of the Most Hon. The Marquis of Salisbury, Preserved at Hatfield House Hertfordshire. Vol. 1: 1306-1571, London, 1883.

- Calendar of the Manuscripts of the Most Hon. The Marquis of Salisbury, Preserved at Hatfield House Hertfordshire. Vol. 2: 1572-1582, London, 1888.

Stevenson, Joseph (ed.), Calendar of State Papers, Foreign Series, of the Reign of Elizabeth 1564-5, London, 1870.

Thurley, Clifford A., and Dorothea Thurley (eds.), Index of the Probate Records of the Court of the Archdeacon of Ely 1513-1857, London, 1976.

Wilkinson, Louise J. (ed.), Calendar of Patent Rolls 27 Elizabeth I (1584-1585) C 66-1254-1270, London, 2002.

—, Calendar of Patent Rolls 32 Elizabeth I (1589-1590) C 66 1337-1361, London, 2004.

\section{Manuscript Collections}

British Library, Cotton Manuscripts.

$\longrightarrow$, Harley Manuscripts.

$\longrightarrow$, Lansdowne Collection, Burghley Papers. 
- Sloane Manuscripts.

Cambridge University Library, Cambridge University Manuscript Collections.

Hatfield House, Cecil Papers.

Longleat House, Dudley Papers.

The National Archives of the United Kingdom, Records of the Prerogative Court of Canterbury.

$\longrightarrow$, SP 12: Secretaries of State: State Papers Domestic, Elizabeth I.

— SP 15: Secretaries of State: State Papers Domestic, Edward VI - James I: Addenda.

- SP 70: Secretaries of State: State Papers Foreign, General Series 1558-1577, Elizabeth I.

— SP 80: Secretaries of State: State Papers Foreign, Holy Roman Empire.

$\longrightarrow$, SP 81: Secretaries of State: State Papers Foreign, German States.

— SP 82: Secretaries of State: State Papers Foreign, Hamburg and Hanse Towns.

$\longrightarrow$, SP 84: Secretaries of State: State Papers Foreign, Holland.

\section{Printed}

Agnello, Giovanni Baptista, Revelation of the Secret Spirit of Alchymie, Richard Napier (trans.), London, 1623.

Agricola, Georgius, De Re Metallica, 1556, Herbert Hoover (trans.), London, 1912.

Alvetanus, Cornelius, 'Epistola de Conficiendo Divino Elixire, Sive Lapide Philosophico', in Lazarus Zetzner, Theatrum Chemicum, Strasbourg, 1661.

Anon., Abstract of the Returns of Charitable Donations for the Benefit of Poor Persons, Made by the Ministers and Churchwardens of the Several Parishes and Townships in England and Wales, London, 1816.

Anon., Bibliotheca Illustrissive Catalogus V ariorum Librorum, London, 1687.

Anon., Cabala, Sive Scrinia Sacra: Mysteries of State and Government in Letters, London, 1691.

Bacon, Francis, 'Apophthegms', in Basil Montague (ed.), The Works of Francis Bacon, London, 1823.

Bagshaw, Christopher, 'A True Relation of the Faction Begun at Wisbech' in Thomas Law (ed.), A Historical Sketch of the Conflicts Between Jesuits and Seculars in the Reign of Queen Elizabeth, London, 1889. 
Bennet, Henry, A Famous and Godly History Contaynyng the Lyves and Actes of Three Renowned Reformers of the Christian Church, London, 1561.

Best, George, A True Discourse of the Late Voyages of Discoverie, for the Finding of a Passage to Cathaya, by the Northweast, under the Conduct of Martin Froblisher Generall, London, 1578.

Bullein, William, Bulwarke of Defence Againste All Sicknes, London, 1562.

Carr, Cecil Thomas, Select Charters of Trading Companies, A.D. 1530-1707, New York, 1970.

Clowes, William, A Briefe and Necessarie Treatise Touching the Cure of the Disease Called Morbus Gallicus, London, 1585.

Cortez, Martin, The Art of Navigation, Richard Eden (trans.), London, 1561.

Dee, John, 'The Compendious Rehearsal', in James Crossley (ed.), Autobiographical Tracts of Dr. John Dee, Manchester, 1851.

— J James Halliwell (ed.), The Private Diary of Dr. John Dee, London, 1842.

—, Meric Casaubon (ed.), A True \& Faithful Relation of What Passed for Many Yeers Between Dr. John Dee and Some Spirits, London, 1659,

Eden, Richard, Treatise on the Newe World or West India, London, 1555.

Eland, G. (ed.), Thomas Wotton's Letter-Book 1574-1586, London, 1960.

Ellis, Henry (ed.), Original Letters of Eminent Literary Men of the $16^{\text {th }}, 17^{\text {th }}$ and $18^{\text {th }}$ Centuries, London, 1843.

Markham, Gervase, Michael Best (ed.), The English Housewife, London, 1615, Reprinted, 1994.

Murdin, William, Collection of State Papers Relating to Affairs in the Reign of Queen Elizabeth, London, 1759.

Naunton, Robert, Fragmenta Regalia or Observations on the Late Queen Elizabeth, Her Times and Favourites, London, 1641.

Philalethes, Eirenaeus, Secrets Reveal'd: or, an Open Entrance to the Shut-Palace of the King, London, 1669.

Scot, Reginald, The Discoverie of Witchcraft, 1584, reprinted New York, 1989.

Sidney, Philip, Steuart A. Pears(ed.) The Correspondence of Sir Philip Sidney and Hubert Languet, Steuart A. Pears (trans.), London, 1845.

Weston, William, Philip Caraman (ed.), William Weston: The Autobiography of an Elizabethan, Philip Caraman (trans.), London, 1955. 


\section{Secondary Sources}

\section{Articles}

Bowden, Caroline, 'The Library of Mildred Cooke Cecil, Lady Burghley', The Library, Vol. 6, No. 1, 2005, pp. 3-29.

Carlson, David, 'The Writings and Manuscript Collections of the Elizabethan Alchemist, Antiquary, and Herald Francis Thynne', The Huntington Library Quarterly, Vol. 52, No. 2, 1989, pp. 203-72.

Copeman, W. S.C., 'The Gout of William Cecil-First Lord Burghley (1520-98)', Medical History, Vol. 1, 1957, pp. 262-64.

Donald, M. B., 'Burchard Kranich (c. 1515-1578), Miner and Queen's Physician, Cornish Mining Stamps, Antimony and Frobisher's Gold', Annals of Science, Vol. 6, No. 3, 1950, pp. 308-22.

Figurovski, N. A., 'The alchemist and physician Arthur Dee: an episode in the history of chemistry and medicine in Russia', Ambix, Vol. 13, 1965, pp. 35-53.

Gascoyne-Cecil, 'The Library at Hatfield House, Hertfordshire', The Library, Vol. 18, No. 2, 1963, pp. 83-87.

Gwyn, David, 'Richard Eden Cosmographer and Alchemist', The Sixteenth Century Journal, Vol. 15, No. 1, 1984, pp. 13-34.

Hadfield, Andrew, 'Peter Martyr, Richard Eden and the New World: Reading, Experience and Translation', Connotations, Vol. 5, 1995/6, pp. 1-22.

Hogarth, D. D., and John Loop, 'Precious Metals in Martin Frobisher's "Black Ores" From Frobisher Bay, Northwest Territories', Canadian Mineralogist, Vol. 24, 1986, pp. 25963.

Kitching, C. J., 'Alchemy in the Reign of Edward VI: an Episode in the Career of Richard Whalley and Richard Eden', Bulletin of the Institute of Historical Research, Vol. 44, 1971, pp. 308-15.

Kocher, P. H., 'Paracelsian Medicine in England: The First Thirty Years (ca. 1570-1600)', Journal of the History of Medicine, Vol. 11, 1947, pp. 451-80.

Parry, Glyn, 'John Dee and the Elizabethan British Empire in its European Context', The Historical Journal, Vol. 49, No. 3, 2006, pp. 643-75.

Pritchard, Allan, 'Thomas Charnock's Book Dedicated to Queen Elizabeth', Ambix, Vol. 26, No. 1, 1979, pp. 56-72.

Pumfrey, Stephen, and Francis Dawbarn, 'Science and Patronage in England, 1570-1625: A Preliminary Study', History of Science, Vol. 42, 2004, pp. 137-188.

Reeds, Jim, 'Solved: The Ciphers in Book III of Trithemius's Steganographia', Cryptologia, Vol. 22, No. 4, 1998, pp. 291-317 
Szulakowska, Urszula, 'The Pseudo-Lullian Origins of George Ripley's Maps and Routes as developed by Michael Maier', Cosmos, Vol. 9, 1993, pp. 107-26.

Wretts-Smith, Mildred, 'The English in Russia During the Second Half of the Sixteenth Century', Transactions of the Royal Historical Society, Vol. 3, 1920, pp. 72-102.

\section{Books}

Alford, Stephen, Burghley: William Cecil at the Court of Elizabeth I, New Haven, 2008.

Arber, Edward (ed.) The First Three English Books on America, Birmingham, 1885.

Ash, Eric H., Power, Knowledge and Expertise in Elizabethan England, Baltimore, 2004.

Ashmole, Elias, Theatrum Chemicum Britannicum, London, 1652.

Atiya, Aziz Suryal, The Crusade in the Later Middle Ages, London, 1938.

Atwood, Mary Anne, A Suggestive Inquiry into the Hermetic Mystery, London, 1850.

Aubrey, John, Natural History of Wiltshire, London, 1847.

Ball, Philip, The Devil's Doctor: Paracelsus and the World of Renaissance Magic and Science, New York, 2006.

Barnett, Richard C., Place, Profit, and Power, a Study of the Servants of William Cecil, Elizabethan Statesman, 1969.

Beckingsale, B. W., Burghley: Tudor Statesman, 1520-1598, London, 1967.

Brock, William, Chemistry, New York, 1993.

Brain, Robert Michael, Robert Sonne Cohen, Ole Knudsen(eds.), Hans Christian Orsted and the Romantic Legacy in Science: Ideas, Disciplines, Practices, Dordrecht, 2007.

Bran, Noel L., Trithemius and Magical Theology: A Chapter in the Controversy over Occult Studies in Early Modern Europe, Albany, 1999.

Brock, William, Chemistry, New York, 1993.

Butterfield, Herbert, The Origins of Modern Science, 1300-1800, New York, 1951.

Campbell, Gordon, Renaissance Art and Architecture, Oxford, 2004.

Caplain, Arthur L., James J. McCartney and Dominic A. Sisti, Health, Disease, and Illness: Concepts in Medicine, 2004.

Challis, C. E., The Tudor Coinage, New York, 1978.

Chamberlain, Frederick, Elizabeth and Leycester, London, 1939. 
Chester Waters, Robert Edmond, Genealogical Memoirs of the Extinct Family of Chester of Chicheley: Their Ancestors and Descendants, London, 1878.

Clucas, Stephen (ed.), John Dee: Interdisciplinary Studies in English Renaissance Thought, Dordrecht, 2006.

Clulee, Nicholas, John Dee's Natural Philosophy: Between Science and Religion, London, 1988.

Collinson, Patrick, The Elizabethan Puritan Movement, London, 1967.

Comstock, John, A Grammar of Chemistry, Cambridge (Mass.), 1825.

Conte, Gian Biangio, Joseph B. Solodow, Don P Fowler and Glenn W. Most, Latin Literature: a History, Baltimore, 1999.

Cooper, Charles Henry, and Thomas Cooper, Athenae Cantabrigienses, Cambridge, 1858.

Croft, Pauline (ed.), Patronage, Culture and Power: The Early Cecils 1558-1612, New Haven, 2002.

Davies, Walter, General View of the Agriculture and Domestic Economy of North Wales, London, 1810.

Debus, Allen G. (ed.), Alchemy and Early Modern Chemistry: Papers from Ambix, Huddersfield, 2004.

—, The English Paracelsians, London, 1965.

- Chemical Promise: Experiment and Mysticism in the Chemical Philosophy, 1550-1800: Selected Essays of Allen G. Debus, Sagamore Beach, 2006.

—, Chemistry and Medical Debate: Van Helmont to Boerhaave, Canton, 2001.

—, Man and Nature in the Renaissance, Cambridge, 1978.

Dewar, Mary, Sir Thomas Smith, London, 1964.

Donald, M. B., Elizabethan Monopolies: The History of the Company of Mineral and Battery Works 1568-1604, Edinburgh, 1961.

Duveen, Denis I., Bibliotheca Alchemica et Chemica: An Annotated Catalogue of Printed Books On Alchemy, Chemistry and Cognate Subjects in the Library of Denis I. Duveen, London, 1965.

Evans, R. J. W., Rudolf II and His World: A Study in Intellectual History 1576-1612, Oxford, 1973.

Fell, Alfred, The Early Iron Industry of Furness and District, London, 1968.

Fell Smith, Charlotte, John Dee 1527 to 1608, London, 1909.

Fernel, Jean, John M. Forrester (ed.), The Physiologia of Jean Fernel (1567), John M. Forrester (trans.), Philadelphia, 2003. 
Fiddler, Paul A., and Thomas J. Mayer, (eds.), Political Thought and the Tudor Commonwealth, London, 1992.

French, Peter, John Dee: the World of an Elizabethan Magus, London, 1972.

Froude, J. A., History of England from the Fall of Wolsey to the Defeat of the Spanish Armada, Vol. 12, London, 1881.

Fuller, Thomas, The History of the Worthies of England, London, 1662.

Fuller, Thomas, The History of the Worthies of Wales, London, 1662.

Furdell, Elizabeth, The Royal Doctors, 1485-1714, New York, 2001.

Furnival, F. J. (ed.), Animaduersions uppon the Annotacions and Corresctions of Some Imperfections of Impressiones of Chaucers Workes (sett downe before tyme, and nowe) reprinted in the yere of oure lorde 1598, London, 1865.

Goodman, David C., Power and Penury: Government, Technology and Science in Philip II's Spain, Cambridge, 2002.

Gough, J. W., The Rise of the Entrepreneur, New York, 1969.

Graves, Michael, Burghley: William Cecil, Lord Burghley, London, 1998.

Greer, Margaret Rich, Walter Mignolo, Maureen Quilligan (eds.), Rereading the Black Legend: The Discourses of Religious and Racial Difference in the Renaissance Empires, Chicago, 2007.

Grund, Peter, "Misticall Wordes and Names Infinite" An Edition and Study of Humfrey Lock's Treatise on Alchemy, Medieval and Renaissance Texts and Studies, Tempe, Forthcoming 2010.

Gunther, R. T., A History of the Daubeny Laboratory, Magdalen College, Oxford, London, 1904.

Hackett, Jeremiah (ed.), Roger Bacon \& the Sciences, Leiden, 1997.

Hamel, Joseph, England and Russia, London, 1854.

Harkness, Deborah, John Dee's Conversations with Angels, Cambridge, 1999.

—. The Jewel House: Eliqabethan London and the Scientific Revolution, New Haven, 2007.

Harrison, G. B., An Elizabethan Journal, Volume 1, London, 1928.

Hart, Vaughan, Art and Magic in the Court of the Stuarts, London, 1994.

Hogarth, D. D., P. W. Boreham, and J. G. Mitchell, Mines, Minerals \& Metallurgy: Martin Frobisher's Northwest Venture, 1576-1581, Hull (PQ), 1994.

Holmyard, Eric, Makers of Chemistry, Oxford, 1931.

Hudson, Winthrop S., Cambridge Connection and the Elizabethan Settlement of 1559, Durham, 1980. 
Hughes, Jonathan, Arthurian Myths and Alchemy: The Kingship of Edward IV, Stroud, 2002.

Hume, Martin, The Great Lord Burghley-Study In Elizabethan Statecraft, London, 1898.

Hurstfield, Joel, The Queen's Wards: Wardship and Marriage under Eilzabeth I, London, 1973.

Ives, Eric, Lady Jane Grey: A Tudor Mystery, Chichester, 2009.

Jayne, Sears, Library catalogues of the English Renaissance, Godalming, 1983.

Jenkins, Rhys, Links in the History of Engineering and Technology from Tudor Times: The Collected Papers of Rhys Jenkins, Freeport, 1971.

Kassel, Lauren, Medicine and Magic in Elizabethan London: Simon Forman: Astrologer, Alchemist and Physician, Oxford, 2005.

Kretzmann, Norman, Anthony Kenny and Jan Pinborg (eds.), The Cambridge History of Later Medieval Philosophy, Cambridge, 1982.

Leedham-Green, Elisabeth, and Teresa Webber (eds.), The Cambridge History of Libraries in Britain and Ireland, Cambridge, 2006.

Lenox, Astor, Bulletin of the New York Public Library, Vol. 3, New York, 1899.

Levack, Brian (ed.), Renaissance Magic, New York, 1992.

Lewis, J. S., Old Glass, London, 1939.

Lindberg, David, and Robert Westman(eds.) Reappraisals of the Scientific Revolution, Cambridge, 1990.

Linden, Stanton J., The Alchemy Reader: From Hermes Trismegistus to Isaac Newton, Cambridge, 2003.

- Dark Hierogliphicks: Alchemy in English literature from Chaucer to the Restoration, Lexington, 1996.

—., Mystical Metal of Gold: Essays on Alchemy and Renaissance Culture, New York, 2007.

Loades, David, The Cecil's: Privilege and Power Behind the Throne, Richmond, 2007.

—, Two Tudor Conspiracies, London, 1965.

Macaulay, Thomas, R. H. Horne (ed.), Scenes and Characters from the Writings of Thomas Babington Macaulay, Oxford, 1846.

McDermott, James, Martin Frobisher: Elizabethan Privateer, New Haven, 2001.

Mackay, Charles, Memoirs of Extraordinary Popular Delusions and the Madness of Crowds, London, 1856.

Madariaga, Isabel de, Ivan the Terrible, New Haven, 2005. 
Matthews, John, (ed.), The Rosicrucian Enlightenment Revisited, New York, 1999.

Merkel, Ingrid and Allen Debus (eds.), Hermeticism and the Renaissance, London, 1988.

Moran, Bruce, The Alchemical World of the German Court, Stuttgart, 1991.

—, Distilling Knowledge: Alchemy, Chemistry, and the Scientific Revolution, Cambridge, 2005. (ed.), Patronage and Institutions: Science, Technology, and Medicine at the European Court, 1500-1750, New York, 1991.

Morris, T. A., Tudor Government, London, 1999.

Nares, Edward, Memoirs of the Life and Administration of the Right Honourable William Cecil, Lord Burghley, London, 1828.

Nauert, Charles, Humanism and the Culture of Renaissance Europe, Cambridge, 1995.

Neal, John, Queen Elizabeth I, London, 1973.

Newman, William R., and Anthony Grafton (eds.), Secrets of Nature: Astrology and Alchemy in Early Modern Europe, Cambridge (Mass.), 2001

Nichol, Charles, The Chemical Theatre, London, 1980.

Nummedal, Tara, Alchemy and Authority in the Holy Roman Empire, Chicago, 2007.

Nutton, Vivian (ed.), Medicine at the Courts of Europe 1500-1837, London, 1990.

Pagel, Walter, Paracelsus: An Introduction to Philosophical Medicine in the Era of the Renaissance, Basel, 1958.

Parry, Glyn, The Arch-Conjuror of England: John Dee and Magic at the Courts of Renaissance Europe, Yale University Press, New Haven, forthcoming 2010.

Patai, Raphael, The Jewish Alchemists: A History and Source Book, Princeton, 1994.

Pelling, Margaret, Medical Conflicts in Early Modern London, Oxford, 2003.

Pepper, John Henry, The Playbook of Metals: Including Personal Narratives of V isits to Coal, Lead, Copper, and Tin Mines, London, 1861.

Plowden, Alison, Danger to Elizabeth: The Catholics Under Elizabeth I, London, 1973.

Pollock, Linda, With Faith and Physic: The Life of a Tudor Gentlewoman: Lady Grace Mildmay 1552-1620, London, 1993.

Principe, Lawrence M. (ed.), Chymists and Chymistry: Studies in the History of Alchemy and Early Modern Chemistry, Sagamore Beach, 2007.

Quinn, David B., The Voyages and Colonising Enterprises of Sir Humphrey Gilbert, London, 1940. 
Read, Conyers, Lord Burghley and Queen Elizabeth, London, 1960.

—, Mr Secretary Cecil and Queen Elizabeth, London, 1955.

Rees, William, Industry before the Industrial Revolution, Vol. 2, Cardiff, 1968.

Riehl Leader, Damian, A History of the University of Cambridge, Volume 1: The University to 1546, Cambridge, 1988.

Roberts, Julian, and Andrew G. Watson, John Dee's Library Catalogue, London, 1990.

Rossi, Paolo, The Birth of Modern Science, Oxford, 2001.

Rubtsov, N. N., History of Foundry Practice in USSR, The Indian National Scientific Documentation Centre (trans.), New Delhi, 1975.

Russell, Joycelyne, Peacemaking in the Renaissance, Philadelphia, 1986.

Ryrie, Alec, The Sorcerer's Tale, Oxford, 2008.

Sargent, Ralph, The Life and Lyrics of Sir Edward Dyer, Oxford, 1935, $2^{\text {nd }}$ Edition, 1968.

Saunders, A. D., Upnor Castle, London, 1967.

Schmitt, Charles B., John Case and Aristotelianism in Renaissance England, Montreal, 1983.

Schuler, Robert, English Magical and Scientific Poems to 1700: An Annotated Bibliography, New York, 1979.

Scrivenor, Harry, History of the Iron Trade: From the Earliest Records to the Present Period, London, 1854.

Seaton, Ethel, Queen Elizabeth and a Swedish Princess, London, 1926.

Smith, A. G. R., The Government of Elizabethan England, London, 1967.

Smith, Pamela H., Business of Alchemy: Science and Culture in the Holy Roman Empire, Princeton, 1997.

Smith, Pamela H., and Paula Findlen (eds.), Merchants \& Marvels: Commerce, Science, and Art in Early Modern Europe, New York, 2002.

Spiller, Elizabeth, Science, Reading, and Renaissance Literature: the Art of Making Knowledge 15801670, Cambridge, 2004.

Stam, David, International Dictionary of Library Histories, Vol. 1, Chicago, 2001.

Stephen, Leslie (ed.), Dictionary of National Biography, London, 1891.

Strype, John, Annals of the Reformation and Establishment of Religion and other Various Occurrences in the Church of England During Queen Elizabeth's Happy Reign, Oxford, 1728, reprinted 1824. 
- The Life of the Learned Sir Thomas Smith, Kt. D.C.L., Principal Secretary of State to King Edward the Sixth, and Queen Elizabeth, London, 1698, reprinted 1820.

Sutherland, N. M., The Massacre of St. Bartholomew and the European Conflict 1559-1572, London, 1973.

Symons, Thomas (ed.), Meta Incognita: A Discourse of Discovery: Martin Frobisher's Arctic Expedition, Hull (PQ), 1999.

Szulakowska, Urszula, The Alchemy of Light: Geometry and Optics in Late Renaissance Alchemical Illustration, Leiden, 2000.

Thomas, Keith, Religion and the Decline of Magic: Studies in Popular Beliefs in Sixteenth and Seventeenth Century England, Oxford, 1971.

Thompson, C. J. S., The Lure and Romance of Alchemy, London, 1932.

Thorndike, Lynn, History of Magic and Experimental Science, 8 Vols., New York, 1923-58.

Thurley, Clifford A., Dorothea Thurley, Index of the Probate Records of the Court of the Archdeacon of Ely 1513-1857, London, 1976.

Trevor-Roper, Hugh, Europe's Physician: The Various Life of Sir Theodore de Mayerne, New Haven, 2006.

Vickers, Brian (ed.), Occult and Scientific Mentalities in the Renaissance, Cambridge, 1986.

Villari, Rosario (ed.), Baroque Personae, Chicago, 1995.

Webster, Charles (ed.), Health, Medicine and Mortality in the Sixteenth Century, Cambridge, 1979.

— Paracelsus: Medicine, Magic and Mission at the End of Time, New Haven, 2008.

Williams, Franklin, Index of Dedications and Commendatory Verses in English Books Before 1641, London, 1962.

Williams, Penry, The Tudor Regime, Oxford, 1979.

Yates, Francis, Giordano Bruno and the Hermetic Tradition, Chicago, 1964.

—, Lull \& Bruno, London, 1982.

— The Occult Philosopby in the Elirabethan Age, London, 1979, reprinted 2003.

—, The Rosicrucian Enlightenment, London, 1972, reprinted 2001.

\section{Online Databases}

Gale Cengage Learning, State Papers Online, 1509-1714, [http://www.gale.cengage.co.uk/statepapers/].

The National Archives of the United Kingdom, 'Currency Converter', 
[http://www.nationalarchives.gov.uk/currency].

Pelling, Margaret, and Francis White (eds.), Physicians and Irregular Medical Practitioners in London 1550-1640: Database, 2004,

[http://www.british-history.ac.uk/report.aspx?compid=17251].

Various, Oxford Dictionary of National Biography, Oxford, online edn., [http://www.oxforddnb.com].

\section{Unpublished Theses}

Besson, Alain, 'Classification in Private Library Catalogues of the English Renaissance, 1500-1640', Unpublished PhD Thesis, University College London, 1988.

Grund, Peter, “Misticall Wordes and Names Infinite”: An Edition of Humfrey Lock's Treatise on Alchemy, with an Introduction, Explanatory Notes and Glossary', Unpublished PhD Thesis, Uppsala University, 2004.

Morrison, G. R., 'The Land, Family, and Domestic Following of William Cecil, Lord Burghley c. (1550-1598)', Unpublished PhD Thesis, University of Oxford, 1990. 